\title{
DANIEI PAUL NEAZOR
}

\section{CROWN IIABILITY IN TORT \\ IN \\ NEW ZEALAND}

Submitted for the degree of Master of Laws at the Victoria University of Wellington 
CHAPTER I. NEW ZEATAND IEGISLATION

1. Crown Suits Act 1881 and Amendments 1

2. Noves for change in the law 13

3. Crown Proceedings Act 195020

CHAPTER II. AUSTRAIIAN IEGISLATION 39

1. The statutory provisions 39

2. Direct and vicarious liability 40

3. Application of private tort law 44

4. Iimitation in respect of purely governmental activities

CHAPTER III. CLAIMS AGAINST THE FEDERAI GOVERINENT IN THE UNITED STATES

CHAPTER IV. PERSOINAI IIABIUITIES IN TORT

OF CROWN SERVANTS AND PUBIIC

OFFICERS

95

1. Introductory

95

- 2. The United States law

97

3. Personal liability of Crown servants (general)

4. Infringement of personal rights or rights of property

5. Military cases 
6. Official communications of state

7. Failure to perform statutory duty

8. Action based on the exercise of statutory powers

9. Acting in excess of jurisdiction

10. Abuse of office

11. Difficulties arising in actions based on the exercise of statutory powers

(i) statutory interpretation 143

(ii) what right of the plaintiff is detrimentally affected

(iii) Whether the Court can properly determine all the issues necessary to found an action

CHAPTER V. VICARIOUS IIABIIITY IN

CROWN PROCEEDINGS

CHAPTER VI. CONCLUSIONS AND SUGGESTIONS FOR REFORM 
INTRODUCTION:

Direct review by the Courts (e.g. by prerogative writs) of Executive acts and decisions generally provides the individual citizen with a means of overcoming for the future the adverse effects of such decisions and actions, but it does not provide any means of compensating him for detriments to his interests already caused. Such detriments will generally be those which have accrued in full by the time the decision is reviewed but may in some cases be of a continuing nature, e.g. where, because of refusal of a licence, a business opportunity is lost.

Tort actions against the State on the other hand, will allow the Courts not only to examine the actions of State servants, and determine whether they conform with the Courts' view of the proper behaviour of officials but also, and principally, to compensate the individual citizen whose interests have been affected by State action. Such actions may thus furnish an indirect means of control of the Executive as well as a means of compensation for injury. cf. Lord MacDermott:

Protection from Power under English Law (1957) pp. 107109, Jaffe: Judicial Control of Administrative Action (1965) pp.237-239. The close relationship of these two aspects of tort actions against the State is 
illustrated by two clauses in the Conclusions of the International Congress of Jurists in New Delhi in 1959 (International Commission of Jurists: The Rule of Law in a Free Society (1960) pp.7 and 8) and the discussions thereon (ibid. pp.85-88), and has been recognised elsewhere - C. Byse: "Non-statutory Judicial Review" (1961) 75 Harvard I.R.1479, 1487/8. The relevant conclusions of the Congress were:

"Clause IV. In general, the acts of the Executive which directly and injuriously affect the person or property or rights of the individual should be subject to review by the Courts. Clause VI. A citizen who suffers injury as a result of illegal acts of the Executive should have an adequate remedy either in the form of a proceeding against the state or against the individual wrongdoer, with the assurance of the satisfaction of the judgment in the latter case, or both."

Conclusions so expressed (and particularly without definition of the word "illegal") seem to put to one side a good deal of thought and conclusions about the functions of the modern State, whatever the political colouration of its government - c.f., e.g. Friedmann, "The Planned State and the Rule of Iaw" (1948) 22 A.I.J.162 and 207 and, carried to its logical end, the first conclusion, of which the second was in this context a corollary, would lead to the situation which some of the deliberators at the Congress feared - that the Courts would in fact be governing the country (ibid p.95). Such a result is 
unlikely to occur so long as legislatures have ultimate control over the Courts, and the Courts themselves exercise a policy of restraint but the conclusions and the reaction to them lead to consideration of very real problems in subjecting the State to tort actions - namely whether there is not a limit to judicial competence in the field of government action, whether, as a matter of economics, some limit must not be put on claims against the State, and whether some restraint on claims is not needed to ensure that public officers are not inhibited in the proper performance of their duty. That there might properly be some limit to judicial competence is perhaps to be based on the difference between the judicial and the executive function. The judicial is a choice between black and white, the determination of which specific individual is to be the successful, and which the unsuccessful, party in a dispute. The executive function is more akin to a choice between all the colours of the range from black through grey to white, and although involving in many cases the determination of an issue as affecting an individual, typically involves the individual's case as a small part of a greater pattern.

American writers in particular seem to recognise this distinction between functions and also the economic issue and the issue going to the inhibition of public officers in the performance of their duty and accordingly 
to be prepared to accept that value judgments must be made as to whether claims in tort will be permitted and if they are, within what area they will be permitted. Historically the basic rule in all common law jurisdictions has been that the State was under no liability in tort at the suit of a subject, the personal immunity of the Sovereign or the inapplicability in his case of the doctrine of respondeat superior having been extended to the political entity of which, in the Commonwealth monarchies, the Sovereign is now the representative: Viscount Canterbury v. Attorney-General (1842) I Phillips 306; 41 E.R.648. It is now generally accepted that claims in tort must be allowed in some areas of State activity, but the proper extent of these areas gives rise to differences of opinion. That the decision in respect of the latter question is a choice of competing values has been accepted by as high a tribunal as the U.S. Supreme Court:

"To be sure, as with any rule of law which attempts to reconcile fundamentally antagonistic social policies, there may be occasional instances of actual injustice which will go unredressed, but we think that price a necessary one to pay for the greater good. And there are of course other sanctions than civil torts suits available to deter the executive official who may be prone to exercise his functions in an unworthy and irresponsible manner. We think that we should not be deterred from establishing the rule which we announce to-day [of absolute immunity of government officers from suits for defamation in respect of official press release on government matters] by any such remote forebodings." - Barr v. Matteo (1959) 360 U.S.564. 
Thus Davis in his Administrative Law Treatise (1958)

Vol.3 s.25-13 accepts that Courts are not necessarily the authority with competence to make final determinations of government policies and government action and that sometimes decisions made in the legislative and executive branches of government should be beyond the area of judicial review ( $p .489)$ and that detriments resulting therefrom should not be compensated through the Courts. His general view is, in this respect, that the line of demarcation must be located on the basis of the propriety of making adjustments between competing values through the medium of damages suits (p.491) and that the basis of that decision must be the qualification of the Court to decide the issue on the one hand and the practicability of exposing the State to suit on the other, accepting that of their nature regulatory powers may injure specific interests.

Professor I.Jaffe in (1963) 77 Harvard I.R.235 et seq. and in his recent book Judicial Control of Administrative Action (1965) pp.232 et seq. also accepts the argument based on competence particularly where the claim is based on negligence in respect of the plaintiff's having been made the "conscious object of an exercise of governmental power intended to alter his position". As he points out, the administrative decision may turn not only on a technical judgment as to the size of the risk and the need to incur it, but also on a political judgment as to who should bear 
the indirect costs ( 77 Harvard I.R. at p.235) and that, when governmental actions are involved, the scale of both the technical and financial factors is likely to be much more complex and extensive than when a similar issue is presented between private persons (ibid.p.236). The U.S. Federal Tort Claims Act at the outset provides for the Federal Government's liability on the basis of a private analogue, but proceeds to limit the general provision by excluding any claim based, inter alia, on the exercise or performance, or the failure to exercise or perform, a discretionary function or duty by a federal employee. It is for the reasons referred to above, Professor Jaffe suggests, that this discretionary exemption may be justified (ibid p.237 and (1957) 70 Harvard I.R.827, 893). In the earlier article (70 Harvard L.R.827) Professor Jaffe, in discussing the justification of the exemption of the State from claims in respect of discretionary functions, made the important point that, apart from the frequently expressed justification that the possibility of actions might stultify decision making and that actions might be a means of subjecting decisions having more of a legislative flavour than a judicial one to judicial evaluation, the concept of fault in tort presupposes the possibility of an objective standard, an idea which may have no application to a resolution of an issue involving policy considerations. Even in other areas of 
governmental activity there may be difficulty in determining standards of liability.

The justifications cited for protection of discretionary acts would appear in general to justify protection on the ground of the Courts' lack of competence to examine decisions, in respect of decisions with a policy content, decisions which affect many i.e. quasi legislative decisions, and perhaps quasi-judicial decisions (c.f. Jaffe ibid p.895/6). Similar conclusions to those of Davis and Jaffe are accepted by Friedmann, Law in a Changing Society (Pelican Ed., 1964) pp.287, 288.

The United States Supreme Court, as will be seen, has concentrated its attention in some cases on the initial provision of the Federal Tort Claims Act and determined the issue by deciding whether there was intended to be liability for the results of "uniquely governmental" activity i.e. activity for which there is no private counterpart, and in other cases has concentrated on the discretionary function exemption, determining the issue by deciding the nature of the functions the discretionary exemption was intended to protect. In the factual situations which have arisen the Court has had to define the inter-relation of the two provisions which, in the form in which they appear in the statute, stand on an equal footing with each other. Professor Jaffe, in the earlier article ((1957) 70 Harvard I.R.827,893) suggested that these two concepts are related 
to each other in that "both a discretionary decision in a non-uniquely-governmental activity and a non-discretionary act in the course of a uniquely governmental activity may involve the same type of governmental considerations" (1957) 70 Harvard I.R. at p.893.

\section{Davis (op.cit. p.501) says that}

"the conventional answer [to whether and when the State should be liable] has been that a governmental unit should be liable, whenever a private party would be liable in the same circumstances. This answer may be sound as far as it goes, but it does not go far enough to reach the most difficult problems. A large portion of the functions of governmental units have no private counterpart. Private parties do not draft men, administer prisons, conduct international relations on behalf of the general public, zone other people's property, enact statutes or ordinances, adjudicate cases, issue administrative orders or regulations that may have the force of law, regulate economic life, or authoritatively determine policies that may be binding upon courts.

The task ahead that is easy to plan is to make governmental units liable in tort whenever a private party would be liable in the same circumstances. The task ahead that is especially difficult is to work out a satisfactory system of liability and immunity with respect to functions that have no private counterpart ... which are uniquely governmental."

This need has also been accepted by others (e.g. Friedmann, op.cit. p.303, Street, Governmental Iiability (1953) p.79).

A further argument against exposing the State to liability to compensate individuals detrimentally affected by state action, additional to that going to the competence of the tribunal, is the simple one based on 
economic practicability i.e. that the cost might be too great cf. e.g. Jaffe 70 Harvard I.R.895,900. The answer to this, to which is related the need to work out better rules in respect of governmental acts, is that a governmental unit is an excellent loss spreader and that by subjecting the State to liability the loss is spread from the individual over the whole community (Davis op.cit. pp.503/4, Jaffe 70 Harvard I.R.900, Street, op.cit.p.79). Even those who accept this answer, however, do not generally suggest that every individual detriment should be compensated, and accept that in some situations (perhaps in all but that where an individual suffers exceptional loss exceeding that of his fellow citizens - Street op.cit p.79) the loss must lie where it falls (Davis op.cit 505). In some areas of Government activity in New Zealand and elsewhere, loss spreading and individual compensation are effected by rules having no reference to fault or tort e.g. by Part III of the Public Works Act 1928.

It thus appears that four questions may be asked as a basis for examining the subjection of the Crown or State to liability to compensate citizens. The first, which is no longer a real issue, is whether the State is to compensate at all the individual detrimentally affected by State action. If it is to do so, the second question is what detriments the State is to compensate. The harms can perhaps be generally grouped as those in respect of 
corporeal property, of personal injury, liberty and reputation, and of an economic nature. The answer to both of these questions is in my view a political and not a legal one. One may rationalize the answer by reference to historic trends, political or legal, but in essence the decision is one of policy.

The third question follows on the answer to the first and second - what is to be the essence of the right to compensation. Is it to be compensation for detriment, as for instance under Part III of the Public Works Act 1928, or damages for wrongdoing? The fourth question is what statutory device is to be used if the action for tort solution is chosen, involving of necessity the question what tribunal is best suited to adjudicate on disputed cases. Various devices have been used and some will be examined in detail. The principal possibilities, alone or in combination, appear to be

(a) to subject the State to claims which it should "in equity and good conscience" meet, and leave it to the Courts to work out case by case a governmental claims or torts law - see Gellhorn and Schenck referred to by -Davis op.cit p.502;

(b) to subject the State to liability for the torts of its servants, with or without limitation in respect of the servant's acts in a "purely governmental" capacity, and to direct liability in respect of every 
enterprise conducted by the State so long as the claim can be brought within the framework of the ordinary causes of action in tort available between private persons (including corporations);

(c) to subject the State to liability to pay damages whenever a servant's ultra vires act causes individual loss;

(d) to subject the State to absolute liability for decisions of the type thought not to be properly subject to judicial scrutiny - Jaffe 70 Harvard I.R.900; (e) to allow government agencies themselves to determine liability and compensation - Jaffe loc.cit. p. 900 ;

(f) to provide that where the functioning of the administrative machine inflicts on an individual exceptional loss exceeding that of his fellow-citizens the State should be liable to compensate that individual even in the absence of fault, and to leave it to the ordinary courts to develop this administrative liability - Street: Governmental Iiability (1953) pp.78-80. The concept of tort liability of an official would be setained only for the determination of whether the public authority could recover a contribution from him; (g) to identify specific areas of discretion e.g. the exercise of licensing powers, the execution of any enactment, the performance of any public duty, the 
inspection of property, etc., and establish by statute a rule of liability or non-liability - California Law Revision Commission referred to by Jaffe, 77 Harvard L.R. 238 .

What I have posed as the fourth question is closely related to, and, indeed, is perhaps part of, the second, but for clarity is best treated as a separate matter. One thing which seems apparent on reflection and to be borne out by examination of various statutory provisions in this field and decisions on them, is that whatever the desired decision of policy may be in respect of the second question, the difficulties and limitations inherent in the statutory devices available for the execution of the policy may of their nature cause that answer to be modified. Thus Professors Gellhorn and Schenck (supra) may have based their statutory device on the best conclusion in respect of the second question but their suggested method of subjecting the State to liability would appear to come very close to undermining what is properly Executive function, rather than controlling or compensating for Executive acts causing damage. As soon as a statutory device is introduced to avoid this result the extent of the remedy becomes restricted.

Professor Street's formula might also be based on the best answer to the second question but his "exceptional loss" test is not helpful. Is any citizen 
who can show actual loss to be accepted as having suffered special loss because the rest of the community has not suffered at all, or is there to be some level at which actual loss becomes special loss and therefore compensatable?

The suggestions enumerated above may be open to objection because of the issues as to whether the Courts should exercise what would normally be regarded as a legislative function, viz. the determination of the nature and extent of State liability, whether the Courts should have the decision in some areas because of the issues involved, the practicability by reason of cost or otherwise of allowing an action, or the difficulty in formulating objective standards and in judging particular cases against the standards. My present purpose is to examine the present New Zealand legislation and case law against the background of other countries' experience in this field in an endeavour to test the suitability of the device we have adopted. 
CHAPTER I.

\section{NEW ZEATAND LEGISLATION}

1. Crown Suits Act 1881 and Amendments

The statutory device presently used in New Zealand (as in the United Kingdom and Victoria) is that the Crown is subjected to the liabilities of a private person vicariously in respect of torts committed by its servants or agents and directly in respect of duties owed to servant by their employer and in respect of duties attaching at common law to the ownership, occupation, possession and control of property (s.6 Crown Proceedings Act 1950). The Crown also has a direct, but limited, liability in respect of breaches of statutory duty. These provisions will be discussed in more detail in their chronological place at the end of this Chapter.

The 1950 Act was not the first such provision in New Zealand. Under s.37 of the Crown Suits Act 1881 a claim could be made against the Crown by petition, which was to be dealt with by the Courts in the same manner as an ordinary action between subject and subject (ss.26, 29 and 32 of the Act), in respect of particular causes of action, provided that a remedy would lie for such a cause of action if the person against whom it could be enforced was a subject of the Crown, and subject to Parliament appropriating money to satisfy the award (s.34: Rayner v. 
The King [1930] N.Z.I.R.44I). Leaving aside breach of contract, the causes of action were

"a wrong or damage, independent of contract, done or suffered by or under [the lawful authority of the Governor on behalf of Her Majesty, or of Her Majesty's Executive Government in the Colony, whether such authority be express or implied] in, upon, or in connection with a public work" (s.37(2)).

Public works in respect of which the Act applied were any railway, tramway, road, bridge, electric telegraph, or other work of a like nature used by the Government of the Colony or constructed by such Government out of moneys appropriated by the General Assembly, and the revenues derived from which formed part of the general revenue of the Colony.

The only commentary on the 1881 Crown Suits Bill to be found in Hansard is the discussion in the Legislative Council of amendments made in the Bill by the House of Representatives (Parliamentary Debates Vol.40 p.478 et seq.). Reference was made to fires caused by railway engines and the killing of stock which wandered onto unfenced railway lines. It was suggested that the Government as representing the general community should not inflict injuries on individuals without compensating them. The following passage reporting the speech of Hon.J. Williamson M.I.C. is of significance in view of the way the Courts subsequently approached the issue of the extent of the liability imposed on the Crown by the Act: 
"If it was not thought that these liabilities should apply to the Government of the country, then he thought the Government of the country should not be allowed to go into all these things that required to be conducted by people who would preserve the interests of the community." (ibid p.480).

The 1881 provision was repeated by $\mathrm{s} .35$ of the Crown Suits Act 1908 and, in a less restrictive form, in ss.3 and 4 of the Crown Suits Amendment Act 1910. The latter sections provided, inter alia:

"s.3. Subject to the provisions hereinafter or in the principal Act contained, a claim or demand may be made against His Majesty by a petition ... in respect of the following causes of action:-

(a) $\ldots$

(b) Any cause of action in respect of which a petition of right will lie against His Majesty at common law;

(c) Any wrong or injury which is independent of contract and for which an action for damages would lie if the defendant was a subject of His Majesty. s.4. Notwithstanding anything in the last preceding section, no claim or demand shall be made against His Majesty in respect of any of the following causes of action:-

(a) Assault, false imprisonment, malicious prosecution, or erroneous judicial process;

(b) Iibel or slander;

(c) Any cause of action in which malicious motive is an essential element."

Section 5 of the Act exempted the Crown from vicarious liability in respect of the actions of the Governor-General, judicial officers and members of the Defence forces and restricted the notion of employer/employee relationship to 
circumstances in which that relationship would exist in the case of subjects. This Act also restricted (by s.9) the amount which could be recovered for death or personal injury to £2,000.

At first sight, the 1910 provision, although wider than that of 1881 because claims were no longer confined to damage related to defined public works, was more restricted because it allowed claims only for wrongs or injuries "for which an action for damages would lie" if the defendant was a subject of His Majesty (s.3(c) of the Crown Suits Amendment Act 1910) whereas s.37(2) of the Crown Suits Act 1881 had allowed claims for a "wrong or damage" unqualified except for the reference to public works. Since, however, s.37 of the latter Act confined all claims to "causes of action ... for which cause of action a remedy would lie if the person against whom the same could be enforced were a subject of Her Majesty" the basis of liability must be taken to have been the same in each case.

It is quite clear that it was not intended by this amendment to open the way for claims in respect of every loss caused by the actions of the Executive. The Bill was to enable "reasonable protection to be given to the country, while at the same time providing proper facilities for those who [had] legitimate claims to make against the Government" (Parl.Deb. Vol.149 p.312). It was intended to 
provide for vicarious liability on the part of the Government in respect of the negligence of most of its servants (per Sir Joseph Ward, P.M. Parl. Deb. Vol.153 p.859), subject to such of the limitations in 5.4 as might be applicable and to the limitation as to the amount recoverable. The basic notion was still that trading activities of the state were the ones to which liability should attach - coalmines, sawmills, railways and fisheries - because an individual injured could sue a private person engaging in such activities (Mr Massey, Leader of the Opposition, Parl. Deb. Vol.153 p.860); but how much notice one should take of Mr Massey's views is doubtful, since he asserted in the same speech that had the Crown Suits Act not been on the statutebook the plaintiff in Barton V. The King (1909) 28 N.Z.I.R. 629 would have been able to sue the Crown without hindrance - (Parl. Deb. Vol.153 p.860). In fact it is clear that Barton could not have sued the Crown apart from the Act, and he failed under the Act because his case was not one within the Act's limited provisions. (post p. 11).

However in his second reading speech, Dr Findlay, AttorneyGeneral, (Parl. Deb. Vol.153 p.930) indicated also that the fact that State enterprises were competing with private enterprise was the substantial reason for extending the Crown's liability.

For present purposes the discussion may be confined to the effect of $\mathrm{s.3(c)}$ and $\mathrm{s} .4$ since at common law no 
petition of right would lie for damages in respect of a tort - Robertson on Proceedings against the Crown (1908) 350 and cases there cited.

The wording of $\mathrm{s} .37$ of the 1881 Act and of $\mathrm{s} .3$ of the 1910 Amendment Act suggests that the Crown was not only made vicariously liable for the torts of its servants but was made directly liable for any wrong by act or omission for which there would be liability if the Crown was a private person. The first time Williams v. The Queen (1882) I N.Z.I.R.222 (C.A.) came before the Court this view seems to have been expressed. The action concerned damage to a ship in Westport Harbour. The suppliant was the owner of the vessel which entered the harbour and under the direction of the Harbour-master was moored at a wharf erected by the Government. The harbour was under the management of the Government which appointed the Harbourmaster and received the revenues of the port. Whilst berthed beside the wharf the vessel settled onto a snag and was damaged. The Harbour-master was aware of the existence of the snag and of the risk it presented to vessels lying beside the wharf but he did nothing about it and did not warn the Master of the vessel of the danger. On a demurrer to a petition of right under the Act Richmond J. accepted on the authority of Mersey Dock Trustees v. Gibbs (1866) I.R. I.H.I.93 that if the wharf had been owned and managed by any body corporate other than the Crown or 
by a private person, a duty of care requiring the bed of the river to be kept clear of obstructions dangerous to vessels would have rested on that body or person, and that neglect of that duty would have been an actionable wrong. He held that an allegation that the Executive Government and the Harbour-master were negligent in leaving the snag was good. No distinction appears to have been made between direct responsibility of the Government and vicarious liability for the acts or omissions of the Harbour-master.

In the Court of Appeal, however, the matter was reduced to responsibility for the acts or omissions of a person acting under the authority of the Government - per Johnson J. at $\mathrm{p} .227$ and Williams J. at $\mathrm{p} \cdot 228$. The issue was not clear-cut because the Harbour-master was alleged to be personally negligent. The question was therefore left open on the demurrer whether if the appropriate Minister had known of the danger, whilst the Harbour-master had not, the plea against the Crown would still have been good.

When the matter came to trial, however, this issue was presented for decision because it was shown that the damage was caused not by the snag of which the Government knew, but by another of which it ought to have known, and that the Harbour-master had not been personally negligent in the matter of berthing the ship. On a rule nisi for a new trial[(1883) I N.Z.I.R.217 (S.C.)] after the 
water snag, the relevant issues and answers of the jury were

(i) "Was Her Majesty's said Executive Government, at the time ... of the events ... and for a long time previously, well aware of the existence of the snag which caused the damage, and of the danger and risk incurred by vessels ... in consequence thereof?

Answer: No; but after the communication from the Harbour Master, if proper steps had been taken, they would have been aware."

(ii) "Did Her Majesty's Executive Government negligently ... suffer the snag to remain ... to the danger of vessels?

Answer: Yes."

The report referred to in the second answer was of the existence of the known (and probably harmless) snag, the conclusion being that if this had been removed the second one would have been found. Although the Court would not apparently itself have answered the second or third issue as the jury did (p.227), once they had been so answered, the Court was not prepared to disturb the finding. As a matter of law the Court said (p.229):

"The finding of the jury no doubt carries the duty of the Government in respect of the removal of obstructions beyond the limit adopted in the judgments given in the Supreme Court and the Court of Appeal on the demurrer. Those judgments only affirm the liability in respect of hidden dangers to vessels occupying the berths alongside, in which they had been placed by the Harbour-

master ... Possibly the verdict carries the liability of Government beyond what is just and reasonable under the circumstances. We cannot, however, say that the finding is contrary to law."

This is clearly a decision that the Government was liable directly under the Act for wrongs done to a private person and that such liability was independent of vicarious 
liability for torts of its servants.

The matter then went on appeal in 1884 to the Privy Council from the decision of the Court of Appeal on the demurrer, but having regard to the facts as determined at the trial. In determining whether there was a duty of care on the Executive Government, the Privy Council considered whether a duty would have existed in the case of private persons maintaining the wharf and inviting ships to visit it, as the Government had done and considered that a duty of care rested on the Government (N.Z.P.C.C.Il8 at pp.125, 126). The Board was prepared to uphold liability on the basis of the failure of the Government by its servants in the exercise of their function fully to investigate and warn of the danger (ibid p.128), but also, it appears, to uphold a direct liability on the Government in respect of the issues set out in full above. At page 129 of the report this passage appears:

"... there was evidence that the Executive Government had before the accident to the "Westport" sufficient notice of the danger to make it their duty to give warning of it, which was not done till after the accident. This was a breach of the duty to take reasonable care."

The appeal was dismissed.

The case of Freeman v. Regina (1884) 3 N.Z.I.R.109 (S.C.) is not of particular interest since it was a claim based on vicarious liability for the negligence of a servant. Interest lies only in the Court's discussion of 
the motive for restricting claims to those in respect of public works from which the Crown derived revenue. Without, of course, referring to the Hansard reports of speeches in the House, the trial judge assigned as the reason that in such cases the Crown was carrying out functions carried out elsewhere by private persons or companies (vide Mersey Docks Trustees v. Gibbs (1866) I.R.I H.I.93) and ought to bear the same liability, but indicated that, in his view, in cases where there had been negligence by servants of the Crown in the exercise of functions "gratuitously performed" (p.114) there was not the same reason for imposing a public liability, and indeed, that it would be difficult to find a private analogue (p.115).

$$
\text { In The King v. Shand (1903) } 23 \text { N.Z.I.R.297 (C.A.) }
$$

a petition under the Act was successfully brought against the Minister of Railways "acting for and on behalf of the King" in respect of damage done to land by reason of a gravel pit excavated by the Department diverting a river so that adjoining land was flooded. The Court of Appeal, however, made no real distinction between a claim made directly against the Government, to which the issues referred ( $p .303$ of the report) and one in respect of vicarious liability for Crown servants (p.306), and the decision therefore does not assist in determining whether, as one would suppose from the words of the Act, a claim lay directly and not merely in respect of vicarious 
liability, for harm resulting from Government operations.

$$
\text { Hankins v. The King (1905) } 25 \text { N.Z.I.R.787 (C.A.) was }
$$

a claim against the Crown in respect of non-repair of a railway crossing. Direct liability under the Crown Suits Act was imposed on the basis that an exact analogy was to be drawn between the Crown acting as a railway authority and a railway company in England, which would owe a duty to keep the highway in repair if it built a crossing over it (per Stout C.J. at p.798, Williams J. at p.800, Edwards J. at p.807, Cooper J. at p.81I and Chapman J. at p.813).

It thus appears clear that under the provisions of the Crown Suits Act 1881 it was not necessary to establish fault on the part of a particular Crown servant vis-a-vis the claimant to found an action, if a direct tortious link between the Crown and the claimant could be established (in respect of the public works to which the application of the Act was restricted) by analogy with the functions or activities of some private person or corporation. It is perhaps a pity that there are no significant decisions of the Courts under the Act, following the amendment of 1910 which removed the restriction of claims to matters arising out of a "public work". The amendment was prompted apparently by the decision in Barton V. R. (1909) 28 N.Z.I.R.629. Barton had been run down and injured by a steam wagon which was being used to carry coal from a depot for the sale and delivery of coal from a State coal- 
mine, the driver of the wagon being alleged to have been negligent. The issue on which the decision turned was whether the damage could be said to have been suffered in, upon or in connection with a "public work" as defined for the purposes of the Crown Suits Act 1881 by s.37 of that Act. The definition did not expressly include a coal min and the court held that it could not be extended to cover one, although admittedly the mine was in ordinary terms a public work. (cf. Parl.Deb. Vol.149 pp.311-3). The decision in The King v. Dubois [1935] 3 D.I.R.209 provides an interesting parallel. Without reported decisions it cannot be said whether the courts would still have sought to draw an exact analogy between operations of the Crown and operations performed by private persons to found direct liability against the Crown, but it is a fair assumption that this would have been so, having regard to the temper of the times and to the fact that the essential wording of the 1881 provision and of the 1910 amendment was in this respect the same [i.e. in providing that an action lay against the Crown only if an action would lie "if (the defendant) was a subject of the Crown".]. The very wording of the statutory provision supports the requirement of such an analogy since the condition precedent is that "for which cause of action" ( 5.37 Crown Suits Act 1881) or "for which [wrong or injury]" an action would lie against a subject. It is quite clear that there would have been vicarious liability under the Act for 
negligence on the part of Crown servants acting in the course of their employment. Since there could apparently be, under the Act, direct liability and vicarious liability one wonders what better result in terms of liability was sought to be achieved by the passing of the Crown Proceedings Act in 1950.

2. Moves for change in the Law:

Attempts were made in 1929 and in 1933 by $\operatorname{Mr}$ R.I. Ziman and by the N.Z. Legal Conference of 1929 to obtain a widening of the Crown's liability in tort but these attempts leave unanswered the difficult questions which arise from the present extent and nature of the Government's operations in the community and the expansion of the scope of negligence as a cause of action in tort. Mr Ziman presented a paper to the Second Annual (sic) Iegal Conference entitled "The Crown in Business: considered from the Constitutional and Legal Standpoints" (1929) 5 N.Z.L.J. 62. His primary concern was the special position enjoyed by the Crown in respect of trading Departments because these Departments, operating in the name of the Crown, enjoyed the privileges of the Crown and the procedural and other limitations reserved by the Crown Suits Act to the Crown. His general argument was along the same lines as that contained in the Hansard references and in the Freeman 
decision referred to above, viz. that the trading Departments should operate subject to the same rules as to liability and procedure as did private traders, if necessary by changing the status of such bodies from that of a Department of State to that of a corporation, capable of suing and being sued. That the question of a wider tort liability in respect of Government action did not enter Mr Ziman's contemplation seems clear from his propositions as to the functions of the State in respect of which the State should have freedom of action and apparently freedom from liability.

The functions which he would include in this category were war, the administration of justice, legislation, taxation, and social services such as the provision of education and the maintenance of public health (ibid p.63/64). Admittedly in referring to the administration of justice, he referred to Salmond's Jurisprudence (1924) 7 Ed. p.139 where this function was described as "the maintenance of peaceable and orderly relations within the community itself - the maintenance of the just rights of the community and its members" but one might well take the reference to be to the operation of the Courts, and not to regulation by the Government.

Following Mr Ziman's paper a remit ((1929) 5 N.Z.I.J. 68) was passed which sought 
"that the Crown Suits Act and the law generally be altered so that actions by or against a Government Department may be instituted by or against such Department in the name of such Department and not in the name of His Majesty the King."

It is clear from the discussion which followed (ibid pp.6872) that amendment was sought in respect of trading Departments, although an endeavour was made to extend the application of the proposed change in the law to what were described as "industrial Departments", the State Forestry Department being the example referred to. This extension would have been one step towards the wide liability in tort which may well now exist against the State i.e. liability in respect of all its functions without restriction arising from the nature of the function.

The matter was referred to the Law Society for consideration, and, apparently as a result, Mr Ziman returned to the attack in 1933 with a proposed Bill. The text of the Bill is given in (1933) 9 N.Z.I.J.248. Its essential provisions were borrowed from the Commonwealth of Australia Judiciary Act 1903. Reserved from its operation were the relationship between the Dominion and the GovernorGeneral and the following functions of government: waging of war; defence; administration of justice; maintenance of law and order; legislation; and the imposition and collection of taxation. In respect of claims not covered by these reservations, the subject could sue the Dominion 
in contract or in tort "as in a suit between subject and subject". The rights of the parties were to be the same as in suits between subject and subject and provision was made for the satisfaction of judgments against the Crown. So that there should be no whittling down of rights against the Crown, the Crown Suits Act was not to apply to claims coming within the Act but should continue to apply in respect of any claim to which it would previously have applied and which was not covered by the proposed new Act. Mr Ziman had introduced his draft Bill with a summary of his previous paper. He referred in passing to the importance of the exceptions contained in 5.4 of the Crown Suits Amendment Act 1910, but again seemed most concerned with the Crown's limited liability under that Act and with procedural advantages derived by trading Departments (ibid $\mathrm{p} \cdot 230 / 1$ ). In a subsequent explanation, however, he referred to the change in substantive law wrought by the proposal, by reference to Farnell v. Bowman [1887] A.C.643 and Baume V. The Commonwealth (1906) 4 C.I.R 97 (which will be considered in more detail later). He referred to Queensland and New South Wales provisions which gave a right of action in respect of "any just claim or demand whatever" against the Government, but preferred the Commonwealth right in respect of claims "in contract or in tort". The reason for this preference was that 
"This definition seems sufficiently comprehensive to include all usual [emphasis mine] types of claim against the Government for which an amendment of the law is desirable; and the Bill makes it clear that, in any case to which the Bill does not apply, the procedure under the Crown suits Act, if previously available, can still be invoked." (ibid. p.259).

This Bill was designed to free the State from liability in respect of the governmental functions described (saving always any actions which could be brought under the Crown Suits Act), but otherwise $\mathbb{M r}$ Ziman could see no ground for distinction between the liability of trading and non-trading Departments. In saying this it seems clear that he had regard to acts performed by the employees of any type of Department (breach of contract, negligent driving of motor vehicles etc.). Unless the special functions of regulatory and other non-trading Departments were intended to be covered by the exceptions they were not adverted to (ibid p.259).

It seems clear from what was written in 1929 and in 1933 that the proposal was to place the Crown on precisely the same footing as the subject when it or its servants engaged in precisely the same activities as the subject. When regard is had to the decisions on the Australian provisions discussed in the next Chapter, however, it appears that the proposed Act would have gone further and made applicable to the field of government administration a remedy by way of damages in tort in respect of governmental 
actions with no private analogue by opening such actions to review in the light of general principles of liability which existed or might be developed in the field of tort.

Nothing further appears to have been done about this whole proposal, the next matter of significance being the enactment of the Crown Proceedings Act 1950. The issue first seems to have been actually raised again when Mr J.T. Watts M.P. asked the Attorney-General in 1947 whether "in view of the great extension of State activities" the Minister of Justice would give consideration to the introduction of legislation giving citizens the right to sue the Crown, both in contract and in tort, without the necessity of complying with the restrictive provisions of the Crown Suits Act. A note to the question indicated that the Crown Suits Act gave special privileges and concessions to the Crown in Court proceedings, placing the private citizen "at a great disadvantage." (Parl.Deb. Vol. 276 p.328). Dr A.M.Finlay M.P. in a later speech in support indicated that the disadvantages were really procedural once the 22,000 limit had been removed and he referred to limitation periods, amendments to pleadings and discovery (Parl. Deb. Vol.276 p.346/7). The Minister's answer was that the United Kingdom bill was being studied to see if similar provisions would be convenient in New Zealand (Parl.Deb. Vol.276 p.328). 
When the 1950 Bill was introduced it contained as to tort the same provisions as the United Kingdom Act of 1947. In moving the Committee stages of the Bill in the House (Parl. Deb. Vol.293, p.4133 et seq.) the AttorneyGeneral, after referring to the increasing entry by the Government into the commercial or industrial sphere (apparently in the sense of operating rather than regulating commercial or industrial undertakings since reference was made to Tasman Fruit Packing Assn. v. The King [1927] N.Z.I.R.518 relating to money lent on mortgage by the State Advances Corporation), said that the Bill was designed to bring the Crown more or less into line with the subject. This reference to the Crown moving into the ordinary commercial arena and the propriety therefore of the Crown being made subject to the same liabilities and disabilities as are subjects, appears twice in a short speech. The same emphasis appeared in the Legislative Council at the committal stage (Parl. Deb. Vol.293, pp.4192, 3).

The other strong emphasis in the speeches on the Bill was on the procedural reforms in respect of actions against the Crown and on the fact that the Crown was to be procedurally in virtually the same position as the subject. The former Attorney-General, Mr H.G.R.Mason M.P. referred in passing to the aspect which is at the root of 
my present consideration when he said (Parl. Deb. Vol.293 p.4134):

"The same problem [of drafting] in New Zealand [as compared with the United Kingdom] has not been so much a question of the remedy that one may have against the Crown or so much the matter of the Crown's liabilities. Before the introduction of this Bill, the Crown in New Zealand had a very general liability, to a greater extent than in England, because some obsolete rules and processes had been abolished here."

This points the questions, next to be considered, whether, procedural matters apart, the Crown in New Zealand is subjected to greater liabilities in tort by the 1950 Act than it was before the new Act, or less, particularly in respect of negligence. The second major issue is whether the Crown's liability in tort is restricted to its commercial and industrial or other activities identical with or analogous to those performed by private individuals or corporations or whether this remedy is available in respect of every sphere of the Crown's operations, including regulatory activities and other functions of government which have no private analogue.

3. Crown Proceedings Act 1950:

The provisions of the Crown Proceedings Act 1950 in respect of claims in tort are the equivalent of the relevant provisions of the Crown Proceedings Act 1947 (United 
Kingdom). There is a similar, but less detailed, provision in s.23(1)(b) of the Crown Proceedings Act 1958 of Victoria. In the New Zealand Act the right to sue the Crown is provided by $\mathrm{s} .3(2)(\mathrm{b})$ in respect of liability in tort, the liability being spelt out by s.6. The provisions of $\mathrm{s} .6$ which will be discussed here are:

"s.6(1) Subject to the provisions of this Act and any other Act, the Crown shall be subject to all those liabilities in tort to which, if it were a private person of full age and capacity, it would be subject -

(a) In respect of torts committed by its servants or agents;

(b) In respect of any breach of those duties which a person owes to his servants or agents at common law by reason of being their employer; and

(c) In respect of any breach of the duties attaching at common law to the ownership, occupation, possession, or control of property:

Provided that no proceedings shall lie against the Crown by virtue of paragraph (a) of this subsection in respect of any act or omission of a servant or agent of the Crown unless the act or omission would apart from the provisions of this Act have given rise to a cause of action in tort against that servant or agent or his estate.

(2) Where the Crown is bound by a statutory duty which is binding also upon persons other than the Crown and its officers, then, subject to the provisions of this Act, the Crown shall,

- in respect of a failure to comply with that duty, be subject to all those liabilities in tort (if any) to which it would be so subject if it were a private person of full age and capacity.

(3) Where any functions are conferred or imposed upon an officer of the Crown as such either by any rule of the common law or by statute, and that officer commits a tort while performing or purporting to perform those 
functions, the liabilities of the Crown in respect of the tort shall be such as they would have been if those functions had been conferred or imposed solely by virtue of instructions lawfully given by the Crown."

Section 6(4) applies to the Crown the benefit of any enactment which negatives or limits the amount of the liability of any Department or officer of the Crown in respect of any tort committed by that Department or officer and s.6(5) exempts the Crown from liability in respect of anything done or omitted by any person while discharging or purporting to discharge any responsibilities of a judicial nature or in connection with the execution of judicial process. Restrictions are placed on the general provision of $\mathrm{s.6}$ by $\mathrm{s.7}$ (relating to industrial property), s.9 as substituted by s.2 of the Crown Proceedings Amendment Act 1962 (relating to death or disablement of members of the New Zealand armed forces), and s.35 (relating to, inter alia, highways). There is also a saving in s.ll as to prerogative and statutory powers, related particularly to defence and the armed forces.

Section 6 gives rise to a distinction between direct liability of the Crown and vicarious liability for the torts of Crown servants. Thus the Crown is directly liable under $s .6(1)(b)$ and $s .6(1)(c)$ and, in respect of breach of statutory duty, under s.6(2). In respect of acts of its servants, however, the Crown is generally 
accepted to be subjected by the Act only to vicarious liability - Street: Governmental Iiability (1953) pp.36 et seq.; Bickford Smith: The Crown Proceedings Act 1947 (1948) p.28; Hall v. Whatmore [1961] V.R.225 at 225 and 228/9; Morgan v. Attorney-General [1965] N.Z.I.R.134 at 136; although the act or omission of a private person's servant may involve his employer in direct as well as vicarious liability:

"There may be a direct duty on the master towards the third person, with the servant the instrument for its performance. The failure on the part of the servant constitutes a breach of the master's duty for which he must answer as for his own wrong; but it may also raise a liability on the servant towards the third person by reason of which the master becomes liable in a new aspect. The latter would result from the rule of respondeat superior; the former does not." - R. v. Anthony [1946] 3 D.I.R.577, 585. See also Darling Island Stevedoring Co. v. Long (1956-57) 97 C.I.R. 36 at p.57.

The inclusion of "agents" ( which term by definition includes independent contractors: $s .2(1)$ of the Act) in the provision relating to torts of servants is somewhat confusing because the liability of a private person in respect of the acts or omissions of independent contractors is direct rather than vicarious: Salmond on Torts 14 Ed. (1965) pp.64l, 686. Section 35(2)(d) of the Act ensures that the liability of the Crown in this respect is not greater than that of a private person. So far as liability resulting from things done or omitted by 
Crown servants is concerned, the plaintiff appears to be in a less favourable position than he would have been under the Crown Suits Act which allowed him to sue the Crown in respect of either the direct or the vicarious liability referred to in the extract from R. V. Anthony above. The difference, as will be discussed in more detail later (post p.157), is of particular importance in respect of actions based on negligence where the issue will arise whether any duty of care for the plaintiff is imposed on the servant as opposed to a duty imposed on the Crown which employs him. As will be seen from some of the Australian cases (post $\mathrm{p} .48$ ) situations may arise in which there is a relationship between the Crown and the plaintiff which gives rise to a duty of care, whilst any duty in respect of the plaintiff's business owed by the Crown servant is owed only to the Crown as his employer. Similar considerations arise in cases where any duty is a concomitant of the undertaking of an enterprise e.g. the provision of lighthouses, the enterprise being undertaken not by the Crown servant, but by the Executive Government. Thus, there appears to be an area where the subject's rights against the Crown may be less under the 1950 Act than they were before this legislation was enacted.

In addition to this matter, it appears that there may be gaps in the pattern of Crown liability established by the Act, arising from the way the statute is drafted, 
the repair of which warrants consideration. Apart from its agents, the Crown's liability under $\mathbf{s . 6}$ is referred to in relation to its "servants" (s.6(1)(a)) or its "officers" (s.6(2),(3)). "Officer" is defined in s.2(1) thus:

"Officer" in relation to the Crown, includes any servant of His Majesty, and accordingly (but without prejudice to the generality of the foregoing provision) includes a Minister of the Crown; and a member of the New Zealand armed forces; but does not include the Governor-General, or any Judge, Magistrate, Justice of the Peace or other judicial officer."

The term "servant" was not defined until 1958 when s.2 of the Crown Proceedings Amendment Act 1958 inserted the following definition in the Act:

"Servant" in relation to the Crown, means any servant of Her Majesty, and accordingly (but without prejudice to the generality of the foregoing provision) includes a Minister of the Crown, and a member of the New Zealand armed forces; but does not include the Governor-General or any Judge, Magistrate, Justice of the Peace, or other judicial officer."

The 1958 amendment has removed doubts as to whether the provisions of s.6(I)(a) applied to torts committed by Ministers of the Crown and members of the armed forces, but it has done nothing to elucidate the question who are Crown servants. Problems may arise in this respect in relation to servants lent or hired by their general. employer - cf. Salmond on Torts 14 Ed. (1965) p.654 et seq. 
suggests that the Crown's liability is intended to be confined to that in respect of servants whose general employer is the Crown. The situation in this respect is clear in the United Kingdom where liability is restricted to the acts, neglects or defaults of officers appointed by the Crown and paid out of the Consolidated Fund or other public funds (s.2(6) Crown Proceedings Act 1947 (United Kingdom)). The only case where this issue appears to have come up for decision is Farthing v. The King [1948] 1 D.I.R.385 where, in respect of an employee loaned to the Crown by the Y.M.C.A., which did not retain control over his work, the Exchequer Court of Canada applied the tests indicated in Century Insurance Co. v. Northern Ireland Transport Board [1942] A.C.509 at 513, 515 and 516 to hold that the Y.M.C.A. employee was a servant of the Crown for whose acts or omissions the Crown would be vicariously responsible. The only statutory provision referred to was s.19(1)(c) of the Exchequer Court Act 1927 (post p.165).

Street, Governmental Iiability (1953) suggests (p.31) that another problem related to the question who is a servant of the Crown is whether the Crown is to be vicariously liable for the torts of the servants of incorporated public bodies which might be regarded as agencies of the Crown - cf. discussion in Tamlin v. Hannaford [1950] I K.B.18. He says: 
"It is not whether anybody is to be vicariously liable for the torts of the servant of the public body, but rather which body, the State or the public corporation, is to be sued. If the Corporation is a servant of the Crown, then its servants will also be servants of the Crown, and the Crown Proceedings Act will apply; the rule that one servant of the Crown is not liable for the torts of another

(Bainbridge V. Postmaster General [1906] I K.B. 178 and other cases referred to) will normally prevent an alternative action against the Corporation from being brought. If the body is not an agent of the Crown, then the action will lie against it alone."

These comments appear to be inaccurate, the basis of the error being the proposition underlined. Nothing is cited by Street to support this proposition and it is suggested that it is on principle not supportable. It is true that the Corporation which is a servant of the Crown will not be suable in respect of the torts of those who serve under it if they are servants of the Crown - see Mackenzie-

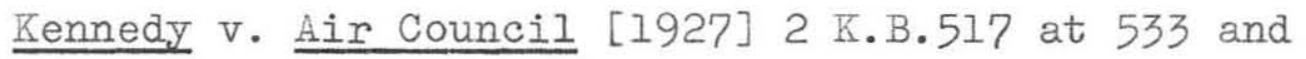
Bainbridge's case but it is going unwarrantably further to say that because a corporation is a Crown servant, its servants will be also. There is thus no real problem; 3 for the servant of the corporation is not a servant of the Crown unless some direct relationship exists between him and the Crown and he does not exercise his functions on behalf of the Crown unless perhaps there is some special statutory provision to that effect - cf. s.3(3) Town and Country Planning Act 1947 (United Kingdom). 
The relation of liability to the acts or omissions of "servants" or officers" of the Crown may also give rise to limitations in the availability of a compensatory remedy in respect of the acts or omissions of persons carrying out public functions who are not otherwise employees of the Crown, e.g. members of administrative tribunals (to the extent that they are not covered by s.6(5) of the Act). This may be of no little importance in New Zealand in view of the large number of such tribunals - see G.S.Orr: Administrative Justice in New Zealand (1964) and the report The Citizen and Power, Administrative Tribunals, Justice Department (1965). It is relevant at this point to note that the definitions of "servant" and "officer" in the Act specifically exclude any judicial officer, so that the Crown would not be liabl under s.6 for the acts or omissions of such officers. Unless therefore the protection in $\mathrm{s.6(5)}$ in respect of anything done or omitted by any person "while discharging or purporting to discharge any responsibilities of a judicial nature vested in him" is to be taken to have been inserted merely out of an abundance of caution, it may be that the Crown will have no liability in respect of acts having a judicial character as opposed to a discretionary, legislative or ministerial one - cf. discussions of these issues in various contexts by de Smith: Judicial Review of Administrative Action (1959) e.g. at 289/90. It would be 
ironical if distinctions which the Courts have drawn for the purpose of permitting judicial review of the acts of administrators should serve to provide an area of exemption of the Crown from liability in tort. It has been said that it is unnecessary on grounds of public policy that immunity from suit for defamation should be extended to every body which is bound to act judicially in the sense of deciding fairly and impartially: Royal Aquarium Society v. Parkinson [1892] 1 Q.B.431. Thus, Glanville Williams suggests that the line of authorities to be chosen in interpreting the United Kingdom provision identical with s.6(5) of the New Zealand Act would be those relating to judicial (i.e. relating to Courts and similar tribunals) immunity rather than those relating to the control of discretion: Crown Proceedings (1948) p.46. Street op. cit. p.42 suggests that there is a good argument to the contrary:

"A recognition of the true basis of this [a Judge's] immunity would surely lead to its extension to administrative tribunals, for there is an interest in the termination of such hearings and in the rendering of full justice there [because participants in adjudications are able to speak freely without fear of the consequences]."

Nevertheless he would prefer to see the State accept liability in all such cases whilst preserving the judge's personal immunity (ibid pp.43, 44). The problem in New Zealand has been exacerbated by the express exclusion of 
judicial officers in the definitions of the terms "officer" and "servant", there being no such exclusion in the United Kingdom definition section - Crown Proceedings Act 1947 (United Kingdom) s.38(2). As matters stand in New Zealand, when account is taken of the definitions referred to in s.2(1) of the Act, s.6(5) is not only open to the wider construction suggested but almost necessarily requires it if all the provisions of thestatute are taken to be intended to have some effect. The definitions of the United States Federal Tort Claims Act are more precise (post p.68).

The next matter arising on the statute is the effect of the provisions of s.6(2) and (3). Sir Thomas Barnes, Treasury Solicitor, indicated the reason for their enactment in an article in 26 Canadian Bar Review 387 thus:

"This provision [New Zealand s.6(2)] at first sight seems somewhat complicated but its purpose is to ensure firstly that the Crown shall only be liable for breaches of statutory duties which bind the Crown and secondly that the Crown shall not be liable for breaches of statutory duties which bind the Crown but do not at the same time bind private persons. The reason for this latter limitation is that there are many acts of Parliament which impose general duties upon particular Ministers, e.g. it is the duty of the Minister of Education to promote the education of the people of England and Wales. Clearly if the Minister fails to perform this duty he should be answerable in Parliament and not elsewhere. As has been previously stated many duties are imposed by statute upon officers of the Crown and the rule of law is when a duty to be performed is 
imposed by law and not by the rule of the party employing the servant the employer is not liable for the wrong done by the servant in carrying out that duty. Subsection 3 of s.2 [New Zealand s.6(3)] deprives the Crown of any defence based on this principle."

Glanville Williams (op.cit. p.48 correctly, it is submitted, summarises the purpose of s.6(2) by saying:

"The object of the Act is to put the Crown on somewhat the same footing as a private master, not to create a new department of tort by turning constitutional and administrative law into a system of duties owed to individuals."

Street (op.cit. p.40) suggests that there is no adequate foundation for this argument:

"If a statutory duty is imposed on public authorities other than the Crown and on no other persons, then there may be an action for breach of it. That rule is satisfactory: it gives to the Courts a latitude in statutory interpretation which enables them to keep a fair balance between the Administration and the citizen. Why should the Crown as an administrative unit be treated differently from other public bodies?"

It is suggested, to the contrary, that there are at least three reasons which support this provision, all of which have been adverted to more fully in the Introduction hereto, viz:

(a) the undesirability of leaving to the Courts for determination the question of policy as to the areas in which the State should be subject to tort actions. This would be the position if it was left to the Courts to determine as a matter of construction whether the statute created only a duty to the public or gave a remedy 
to private persons - see Salmond on Torts 14 Ed. (1965) p.352 et seq.;

(b) Government activities are much more likely to involve general issues of policy than those of private persons or of corporations set up to administer particular enterprises, and this raises the issue whether the Courts are the proper authority to determine such issues;

(c) the cost of exposing Government activities as a whole to private actions in the Courts may be prohibitive.

So far as the general duties imposed on Ministers referred to by Sir Thomas Barnes is concerned, however, s.6(2) is less often of importance in New Zealand than its counterpart may be in the United Kingdom, because of the difference in the formulas generally used in United Kingdom and New Zealand statutes establishing Government Departments. In the United Kingdom, the formula sometimes imposes a duty on the Minister to carry out the administration of the Act. Thus s.l of the Education Act 1944 (United Kingdom) provides that

"It shall be lawful for His Majesty to appoint a Minister ... whose duty it shall be to promote the education of the people of England

Similar provisions appear in $\mathrm{s} .2(1)$ of the Ministry of Transport Act 1919, s.I of the Ministry of Fuel and Power Act 1945, s.l of the Ministry of Town and Country Planning Act 1943, but not in the Ministry of Supply Act 1939, the Minister of Works Act 1942 or the Ministry of National Insurance Act 1944 where the references are to "powers" or 
"functions" only. In New Zealand on the other hand the usual practice is to charge the Minister with "the administration of this Act" - s.3 Civil Aviation Act 1964, s.4 Education Act 1964, s.9 Social Security Act 1938; to impose "functions" which seem to have the character of powers rather than duties, on the Department - s.4 Civil Aviation Act 1964, s.14 Forests Act 1949; or simply to confer powers on the Minister - Government Railways Act 1949. One exception is the Hospitals Act 1957, s.3 of which lays down the Minister's functions in terms of duty.

Section $6(3)$ has the contrary effect to s.6(2) in that it removes a defence instead of continuing one. The subsection was plainly intended to overcome the effects of such decisions as Stanbury v. Exeter Corporation [1905] 2 K.B.838; Enever v. The King (1906) 3 C.I.R.969 and Baume V. The Commonwealth (1906) 4 C.I.R.97 (referred to post p.41). The only problem which might arise in relation to s.6(3) is whether it will have any application when the wrong complained of is a breach of the statute which itself imposes a duty on the Crown officer. It is at least arguable that the reference in s.6(2) to statutory duties binding persons "other than the Crown and its officers" indicates the intention of the Iegislature that an action should lie when the duty binds the Crown, Crown servants and private persons, but that there should be no 
action for breach of any statutory duty imposed only on a Crown officer (by definition, including a Crown servant), the limitation not being confined to the general public duties referred to by Sir Thomas Barnes. The wording is as apt to the one result as to the other. Furthermore, in respect of a complete failure to perform a statutory duty e.g. the duty imposed on a Receiver of Wreck by s.343 of the Shipping and Seamen Act 1952, the wording of s.6(3) does not appear to be apt to the case and it is of doubtful application in respect of a failure properly to perform such a duty. It is also not irrelevant to consider that Fullager J. in Darling Island Stevedoring Co. v. Iong (1956-57) 97 C.I.R.35 at p.56 regarded the application of the term "tort" to a breach of statutory duty as a misuse of the term. Moreover, it is toleraby clear that the operation of $\mathrm{s.6(3)}$ is not intended to depend on the nature of the tortious act but rather to relate to the circumstances which led the servant to perform it i.e. whether he is functioning as a servant of the Crown or because the function has been imposed on him as an individual and without reference to his status as a Crown servant. If the decision in Darling Island Stevedoring Co. v. Iong (1956-57) 97 C.I.R. 35 is correct, the answer to the problem posed does not very much matter because a private person would not be 
vicariously liable for failure of his servant to perform a statutory duty imposed on him personally, (but see criticism by Fleming 20 M.I.R.655 and I.C.I. v. Shatwell [1964] 2 All E.R.999, (H.I.) at 1013-4 where the matter is said to be still open in the United Kingdom). If Long's case should prevail the effect of the decisions in Stanbury's case, Enever's case and Baume's case and the reasoning on which these were based has, at least in respect of statutory duties, re-entered the field of Crown liability by the back door, having apparently been ushered out by way of the front door in 1950. If the decision in Long's case does not prevail, the intention behind s.6(2) and s.6(3), so far as they affect the same matters, needs to be more clearly spelt out.

Turning to the question whether the Crown.'s liability in tort under the 1950 Act is restricted to its commercial and industrial or other activities identical with or analagous to those performed by private individuals or corporations, which is apparently what the legislators sought (see discussion above, pp. 13-20) it must be said that it seems unlikely that such a restriction can be read into the provisions of the Act. The argument that a private analogue is necessary to found liability is supported by the provisions of $\mathrm{s.6(2)}$ relating to breach of statutory duty, but support for the 
contrary argument can be derived from s.6(3), which removes a defence in respect of what would normally be functions of a governmental or official nature - cf. Stanbury's case, Enever's case and Baume's case (supra). The provisions of s.6(l) of the Act do not give much indication of Legislative intention one way or the other. The key words of the subsection for this discussion are "the Crown shall be subject to all those liabilities in tort to which, if it were a private person of full age and capacity, it would be subject...". On one argument, those words would restrict the Crown's liability to cases in which there was to be found an exact private analogue. On the other, the intention behind them was no more than that the rules are abrogated that the Crown as the nominal head of the Executive Government cannot commit a tort and is not vicariously liable for the torts of its servants. It is not proposed to discuss these arguments in detail here because the decisions of the United States Supreme Court on the effect of similar words in the United States Federal Tort Claims Act, which are discussed later (Chapter III post) illustrate the effect of both views, and it is likely that a New Zealand Court would take a view similar to that which the United States Supreme Court reached after several shifts of opinion. 
In addition, however, to arguments based on indications of legislative intention to be derived from the likely results of the adoption of either view, for two reasons the second conclusion, i.e. that the only intention was to abrogate the two rules referred to, seems to be preferable. One reason is based on the wording of the New Zealand statute, the other on the law which applied prior to the passing of the 1950 Act:

(a) the words in s.6(1) underlined above really qualify not the word "tort" in the section, but the word "liabilities". If the phrase "liabilities in tort" was reduced simply to "liabilities", the meaning of the sub-section would not be changed. The torts in respect of which liability arises are the torts of the servant, and in respect of the torts themselves there is no qualification by reference to functions performed by private persons. Furthermore, s.6(I)(a) refers to torts "committed by its [specifically the Crown's] servants or agents". By definition "servants" includes Ninisters as such and members of the armed

- forces, and in respect of neither is there a private analogue. Had the wording of the sub-section been "the Crown shall be subject to all the liabilities in tort of a private person of full age and capacity (a) in respect of torts committed by a servant or an agent" etc., and had the word "servant" not been 
defined as it has for the purposes of the Act, the argument that the Crown was intended to be liable only where a private analogue could be found would have been strong. Such an argument could be advanced in respect of the provisions of the Crown Suits Acts, but seems untenable in respect of the present provision.

(b) it could be argued for the contention that the Act was only intended to make the Crown liable when there was an analagous private liability, that if this view was not adopted, the liability of the Crown in tort would not be the same as the ordinary citizen's (which is what appears generally to have been thought to have been needed - cf. discussion in part II of this Chapter and Adams v. Naylor [1946] A.C.543 and Royster v. Cavey [1947] K.B.204 (C.A.)) but greater, since servants of the Crown can incur personal liability in tort in respect of the conduct of their official functions which may have no private analogue. The short answer to this is that such a result is more likely than not to have been intended by the original draftsman since the view

was long ago expressed that the Crown should, by indemnifying the Crown servant, pay for detriments so caused: Rogers v. Rajendro Dutt (1860) 13 Moo. P.C.C. 209, 236; 15 E.R.78. By providing a direct right of recourse against the Crown in such cases, the 
Legislature would provide a defendant worth suing and, in effect, remove what could be a heavy and sometimes an intolerably unfair burden (cf. Barry v. Arnaud, post p.120) from public servants.

From the matters discussed in this Chapter, it appears that the principal desire of the New Zealand Parliament in enacting the Crown Proceedings Act 1950 was to bring the Crown's liability in respect of circumstances which had a private tort analogue into line with that of the private citizen, and to remove the procedural advantages which the Crown had as a litigant under the existing law. By adopting the United Kingdom legislation and shifting the qualification of analogy with private persons from the cause of action to liability for the servant's tort, it appears that the Legislature has provided for claims arising in a much wider field than the Hansard reports would indicate was intended, and has, to some extent at least, moved administrative law further into the field of tort. The matters in the administrativt law field which could be used to provide a basis of liability on the part of the Crown are discussed later (Chapter IV). 
CHAPTER II. AUSTRALIAN LEGISLATION.

1. The Statutory provisions:

The provisions which will be principally considered in this Chapter are those of New South Wales and the Commonwealth. They present devices for subjecting the State to liability which are similar to, and at least as wide in their scope as, those of the New Zealand Crown Suits Act 1881 and Crown Suits Amendment Act 1910. The decisions on them are of value in indicating the judicial approach to the application of such provisions in circumstances involving government activities which do not always have a private analogue. The New South Wales Claims against the Government Act (Act of 39 Vict. No.38) authorised "any person having or deeming himself to have any just claim or demand whatsoever" against the Government of the Colony to bring his claim before the Court by way of petition. On any such petition the rights of the parties were to be "as nearly as possible the same ... as in an ordinary case between subject and subject". The current New South Wales provision is to the same effect: Claims Against the Government and Crown Suits Act 1912, ss. 3 and 4 .

The Commonwealth provision, contained in ss.56 and 64 of the Judiciary Act 1903, is similar, if more precisely worded: 
"S.56. Any person making any claim against the Commonwealth, whether in contract or in tort, may in respect of the claim bring a suit against the Commonwealth ...

s.64. In any suit to which the Commonwealth … is a party the rights of parties shall as nearly as possible be the same ... as in a suit between subject and subject".

2. Direct and vicarious liability:

Under these provisions, one area of difficulty, already adverted to in consideration of the New Zealand Act, has been eliminated. That is the issue whether the Government is subjected by the statute to direct liability or only to vicarious liability for torts of its servants. The Australian Courts have held that the Crown can be both directly liable and vicariously liable for wrongful acts or omissions of its servants.

The one exception to this general rule is that situation in which a servant is designated by statute to perform a particular duty and in so doing to form an independent judgment. Here there can be no direct lriability because the servant and not the State is charged with responsibility; there is no vicarious responsibility because the servant's right to form an independent judgment excludes the operation of the maxim respondeat superior. In such cases the servant is doing his job in 
his own way: Enever v. The King (1906) 3 C.I.R.969

(arrest by a police constable); Baume v. The Commonwealth (1906) 4 C.I.R.97 (collector of customs passing entries) cf. Stanbury v. Exeter Corporation [1905] 2 K.B.838. It has been suggested above that s.6(3) of the New Zealand Crown Proceedings Act 1950 was primarily designed to overcome the effect of these decisions.

As to the general rule, in Farnell v. Bowman (1887) 12 App. Cas. 643 the Privy Council held that the New South Wales provision extended the right to make claims against the Government to claims in tort, including claims for damages for a tort committed "by the Government by its servants" (at p.648).

In Baume's case there were counts in trespass, detinue and breach of statutory duty not based on matters placed by the statute on the shoulders of the officer, but attributable to or imposed on the Commonwealth or the Department generally, viz. in respect of the detention of books and documents and in respect of a provision that copies of impounded books or documents should be supplied by the Department. In respect of such matters it was held that an action would lie against the Commonwealth see e.g. (1906) 4 C.I.R. at p.116. The Court found no occasion to distinguish clearly between direct and vicarious liability, the act or omission involved always being that of a servant since of necessity a Government 
acts through its servants, (e.g. per O'Connor J. at 119, 123) but held that liability arose wherever the duty lay e.g. per O'Connor J. at 120:

"In all these cases [breach of contract, wrongful interference with property, neglect of statutory duty] the plaintiff must show, against the Commonwealth just as against an individual, that some wrong has been committed by the Commonwealth through its servants, for which the Commonwealth is responsible, or that some duty has been imposed on the Commonwealth, either directly or through its servants, for a breach of which the Commonwealth is liable."

o'Connor $J$. was prepared to assimilate the Commonwealth and its servants to relate the duty and breach sufficiently to give a cause of action, thus:

"Where Parliament has regulated the administration of a Department, and has imposed duties upon the Commonwealth ... the Commonwealth is liable for the breach of that duty by its servants." (p.123).

This principle was spelt out again by Iatham C.J. in Field V. Nott (1939) 62 C.I.R.660, 670 where he said:

"It is not necessary to enquire whether there was carelessness on the part of the officer in question - that question does not arise unless either the officer owed a duty to the plaintiff and the Government was responsible to the plaintiff for the performance of that duty, or the Government itself owed a duty to the plaintiff which the officer was selected to perform."

The most direct expression of the principle that the State could be directly liable in tort at the suit of the subject appears to be that in Zachariassen v. The 
Commonwealth (1917) 24 C.I.R.166 where it was held on a demurrer that the Commonwealth could be liable in a suit for damages for an arbitrary refusal to issue a clearance under the Customs Act although the officer of the Department concerned was not himself liable. The wrong concerned appears to have been breach of statutory duty.

In an apparent deviation from the dual approach, Windeyer J., after referring to the proposition in Field $\mathrm{v}$. Nott (supra) and to Shaw Savill \& Albion Co. v. The Commonwealth (1940) 66 C.I.R.344 and Asiatic Steam Navigation Co. v. The Commonwealth (1955-56) 96 C.I.R.397 said in Parker v. The Commonwealth (1965) 112 C.I.R. 295 (an action based on negligence arising out of the sinking of H.M.A.S. "Voyager" in 1964) that

" the Commonwealth is only liable for the acts or omissions of a servant if that servant would himself be liable: cf. Hall v. Whatmore [1961] V.R.225 at p.229."

Unless this comment is confined (as, from its context, it may be intended to be) to vicarious liability for the torts of servants this view seems quite inconsistent with the view taken by the High Court in the previous cases, at least so far as the tort of negligence is concerned (see e.g. the cases referred to and Zachariassen $v$. The Commonwealth (supra)), and to be unjustified in relation to the Commonwealth provision. Reliance on Hall v. Whatmore is misleading unless the proposition is confined as 


$$
44 .
$$

indicated, since the statutory provision there, markedly different from the Commonwealth one, approximates that of s.6(1)(a) of the New Zealand Crown Proceedings Act 1950.

3. Application of private tort law:

On their face, statutory provisions such as the Australian ones referred to appear to give the Courts considerable room for creative activity in determining and fashioning the Government's liability in tort. In the New South Wales and Commonwealth provisions the only qualification which might require the finding of a private analogue before an action can succed against the Crown is the phrase "as nearly as possible ... as in a suit between subject and subject". A Court in this situation would appear to have a choice open to it of three courses of action, viz:

(a) to apply a strict requirement of a private analogue before accepting that a claim lies against the State;

(b) to require only that the plaintiff be able to set up as a basis of his claim one of the recognised causes of action in tort, whether or not the circumstances giving rise to the claim can be duplicated between private persons. This course leaves the Court a good deal of flexibility particularly in actions based on negligence;

(c) to attempt to create a governmental tort liability, perhaps on a basis of recompense for harm done. 
The High Court of Australia has adopted the middle course, and has established as its approach the testing of the Government's liability by reference to the recognised causes of action as they apply between private party and private party, so that to succeed against the Crown, the litigant must present his case on the basis of such a cause of action. This is not a requirement that a complete private analogue must be demonstrated before an action will lie against the State. Were that the case, as is illustrated by Feres V. U.S. (1950) 340 U.S.135 (discussed in Chapter III p.69 post), there would be no action in respect of wrongful customs! seizures or unauthorised acts done in the course of administration of regulatory legislation, and the High Court has admitted such actions.

The private law cause of action approach was affirmed by Dixon $J$. in James v. The Commonwealth (193839) 62 C.I.R.339 when exploring the effect of invalidity of legislation on claims in tort against the Government. This decision was one of many in protracted litigation by in James in respect of the control of the dried fruit industry in South Australia. In this case he sued the Commonwealth for damages for the loss which he suffered in his trade in dried fruits in consequence of the administration and enforcement of Acts of the Commonwealth 
46.

Parliament and regulations thereunder which had been held to be invalid. In general the damage resulted from the existence of the Act and regulations but also from the acts of the Crown's officers causing carriers not to carry his fruit inter-state on the grounds that to do so would be illegal. The claim was based on two distinct causes of action: trover in respect of the seizure of specific parcels of dried fruit, and unlawful interference with trade in respect of the steps taken in the administration and enforcement of the statute and regulations. The latter claim, which was very widely expressed, was discussed in the judgment in terms of the actions at common law for conspiracy, intimidation, and inducing a breach of contract.

It was held that it was no answer on the part of the Commonwealth to a claim in tort that the acts complained of were done by officers relying upon void legislation for their authority, the Crown being liable for the tortious acts of its servants acting under its de facto authority. However, the question whether a government action was and owb bry thr thenalluw wrongful was to be determined by the general law, the invalidity of the statutory provision going only to the nullifying of a justification (at p.362). The plaintiff succeeded in four of his claims in trover on the basis that the seizures were made under invalid regulations and were 
therefore not authorised by law. The main claim, that in respect of interference with trade, failed on a consideration of the ordinary law which would apply between private persons, as it would apply to the instant circumstances. Thus the argument based on the tort of unlawfully inducing a breach of contract failed because the persuasion or inducement offered to the carriers, an intimation by the Government's officers, in good faith, that the law required the carriers not to carry the plaintiff's produce and that the Government, being charged with the execution of the law, would take proceedings to enforce it, was not a wrongful inducement within the ordinary law.

That the existence of a right of action for damages must be based on a tortious (in private law) act by the Crown or its officers, and not merely on an unauthorised act again appears from the judgment of Iatham C.J. in McClintock v. The Commonwealth (1947) 75 C.I.R. 1,19:

"The Commonwealth does not incur any liability because Parliament or some subordinate Federal legislative authority makes an invalid statute or regulation. Neither does the

- giving of directions in the course of administration of such a statute or regulation create any right of action against the Commonwealth unless there is some infringement of a right of the plaintiff; see Riverina Transport Pty. v. Victoria (1937) 57 C.I.R.327, 34l72. If as in James's easen there had been a seizure of the plaintiff's fruit against his will, so that there was 
prima facie an actionable trespass, and if the only defence was that the seizure complained of was authorised by a statute or regulation which was held to be invalid, there would have been a liability in tort. But in the present case nothing was done to which the plaintiff did not consent." [under a mistake of law].

So also in Asiatic Steam Navigation Co. V. The Commonwealth (1956) 96 C.I.R.397 (an action in respect of improper navigation of a Commonwealth ship, not a warship), Dixon C.J., MeTiernan and Williams JJ. said at $\mathrm{p} .416 / 7$ that the Judiciary Act imposed "upon the Commonwealth a substantive liability in tort ascertained as nearly as may be by the same rules of law as would apply between subject and subject ... [Y] ou look to the substantive law as between subject and subject as the basis of the delictual liability of the Commonwealth."

The private cause of action approach will not provide a remedy in every case of detriment caused by the Crown's operations, even with the removal of the effect of the distinction between direct and vicarious liability. Lacunae have been demonstrated in Australia in respect of actions for both breach of statutory duty and negligence. Thus in Zachariassen's case (supra) the distinction was made in relation to the effect of statutory provisions, between provisions which regulated matters as between the Commonwealth and its officers i.e. indicated which officers were to perform specified functions, and those which 
regulated functions as between the Crown and the subject. The individual could not base an action against the servant on provisions of the former class, but could base one directly against the Commonwealth on provisions of the latter class. It is clear from this decision that the problems which it has been suggested above ( $\mathrm{p} .30$ et seq might exist in New Zealand in respect of actions for breach of statutory duty have not troubled the Australian Courts. A similar distinction between responsibility of an officer to the Government which employs him for the manner in which he performs his duties and responsibility to every person who might be affected by the manner in which he performed his duties was made by Latham C.J. in Field v. Nott (1939) 62 C.I.R.660, 669, and in Carpenter's Investment Trading Co. Itd. V. Commonwealth (1952) 69 W.N. (N.S.W.) 175 noted in (1952) 26 A.I.J.320, in which one cause of action in negligence failed on the basis that the servants of the Commissioner of Taxation owed no duty to the plaintiff, but only to the Commissioner, and therefore could not be negligent to the plaintiff. The same distinction was applied in Revesz V. The Commonwealth (1951) 51 S.R. (N.S.W.) 63 where judgment was given for the defendant in an action to recover damages in respect of financial loss caused by negligence on the part of the Minister of Customs or his departmental officers whereby the issuing of licences to 
import goods was unduly delayed, or by the failure of any such officer to hand the licence document to the applicant promptly.

\section{Limitation in respect of purely governmental activities.}

Although the Australian Courts have as a general rule adopted as the basis of the tort liability of the State the substantive law relating to causes of action available between subject and subject, a few of the decisions suggest that a remedy will not be held to be available in respect of all the State's activities. The result of this qualification of the general rule is that although the facts of the instant case can be fitted within the framework of a cause of action available between private persons, the right to bring suit in tort against the State may be denied for reasons of social policy in respect of some peculiarly governmental activities. Thus A.H.Simpson J. in Davidson v. Walker (1901) I S.R. (N.S.W.) 196 (a decision to which more detailed reference will be made below), in deciding that an action against the Crown was not intended to lie under the New South Wales Claims Against the Government Act in respect of nuisance from a prison, based his decision in part on a distinction between activities of the State 
which are analagous to those of profit earning private corporations and those in respect of which no such analogy can be drawn. Having held that a private person would be liable in the circumstances he said:

"But the Government seems to me to stand in a different position from a body of private persons. The latter are generally authorised to carry out certain works, not bound to do them; they in general derive some benefit from the works authorised, either revenue, as in railways, docks etc., or in gratifying their philanthropic instincts, or in other indirect ways, as in the case of hospitals etc. But the Government is bound, in the administration of justice and for the peace and quietness of the realm, to maintain courthouses, prisons and lockups ... The maintenance of prisons and lockups is not a source of revenue, but the discharge of an onerous and unpleasant duty incumbent on the Governments of all civilised countries ... The position of the Government in this case is, therefore, far stronger than that of a railway company, who are simply authorised to carry out work which will, no doubt, benefit the public, but will also produce a large revenue to the stockholders." (p.210).

If Simpson J. was suggesting that to found liability against the State an exact and complete private analogy would always be required, the suggestion has not achieved viability in the judicial approach to the issue, as indeed is obvious from the later cases already referred to where liability has been held to exist, see e.g. Zachariassen's case (refusal by Customs to issue a clearance); James' case (administration and enforcement of the Dried Fruits Act - a regulatory provision); McClintock's case (an action for conversion, which related to the administration 
of legislation controlling the sale of pineapples) and the Shaw Savill \& Albion Co. case (negligence in the operation of a warship in respect of lookout, speed and course followed).

The general proposition laid down in Davidson's case that there is some area of governmental activity to which the action in tort should not extend, has not however entirely dropped out of sight. This case was an action in nuisance based on the construction and maintenance of a police lock-up in which were confined drunken and disorderly persons, on land adjacent to the plaintiff's dwelling. A second basis of the claim was that the actual construction of the lock-up was negligent inasmuch as if it had been differently constructed, the nuisance to the plaintiff would have been minimised or entirely removed. In non-suiting the plaintiff, the trial judge (Owen J.) said that it was accepted that the Government had uncontrolled discretion to erect the lock-up, which was of its nature likely to be a source of nuisance, but, again of its nature, a necessary work in the community (p.198). He concluded, by analogy with cases relating to a statutory discretion as to the use of land, that the Government's exercise of its discretion in respect of all public buildings which might be a source of nuisance was not open to review by the Courts, although he modified this view by 
accepting on the basis of the same cases that the Court could act in cases of discretionary decisions which resulted in "an outrageous use" of the land (p.201). The ratio of the decision was clearly that notwithstanding the wide wording of the statutory provision giving the right to sue the Crown, there was an over-riding element of public policy which limited the ambit of this right:

" What plaintiff complains of is that the Government ought not to have constructed these buildings and walls as they did, because he is annoyed by the sounds. It appears to me that it would be entirely contrary to public policy if, every time the Government had to erect a building of this kind, they were to be subjected to an action by persons living in the neighbourhood, because these persons thought they ought to have been put up in some different way ... [T] $\quad[\mathrm{T}$ Government would be harassed by endless actions of this kind ... I am of opinion that it is a matter entirely within the discretion of the Government, and I am now asked to substitute for that discretion the discretion of the court. It is a discretion which must be left to the Government and the Government alone, and if the Court entertained the action, then possibly on the conflicting evidence of experts it would be left to the absolute discretion of a Judge and jury to determine how the Government in these cases ought to have erected these buildings. The Government appoint their own architect and

- their own expert artificers who know exactly the kind of building required for these offices, and they are built accordingly, and it appears to me that that is a matter which must be left entirely to their discretion." (pp.199-200 of the report). 
Act 1897 gave the subject the same rights against the Government as a subject would have against a fellow subject. Although it was agreed by Owen $J$. that the Act enlarged the remedies which the subject would have against the Crown, he would not accept that the rights between subject and Crown were in every respect the same as between subject and subject. As to the effect of the statute, he said:

"That is really providing only that the proceedings are to be exactly the same as between subject and subject, and the rights of the parties in this proceeding are to be dealt with just as if the case was between subject and subject. It appears to me, therefore that the Act does not in any way assist plaintiff ..." (ibid p.202).

Insofar as this is a denial of the creation of a new right of action against the Crown it seems to be wrong, because apart from statute there is no such right in tort, and Farnell's case is authority for the proposition that a right in tort does arise from the statute.

The over-riding limitation on the right to sue the Crown, which Owen J. had based on general public policy was, however, endorsed on appeal. It was accepted by Stephen J. that the Government must act in the public interest, even although this might cause some detriment to private interests and that it must accordingly have "a large degree of immunity from action in the exercise of those functions" which were of a "higher character" than those 
of a private railway corporation ( $\mathrm{p} .207$ of the judgment). Again, referring to the cases relating to statutory discretions in respect of the use of land, Stephen J. held that it would be "impolitic and not competent for Courts and juries to ... control the Government in such matters and to dictate to them how, in the light of future eventualities ... their gaols and lockups must be erected" (ibid pp.207,208). These comnents were perhaps obiter, but more likely one of two rationes either of which supports the decision. A.H.Simpson J. delivered a concurring judgment based on the public policy issue, the third judge concurring with Stephen J.

A.H. Simpson J. held that a private person would be liable in the circumstances for nuisance, but distinguished the Government's position from that of a private person because of a difference in the nature of the Government's functions in issue. Referring to Hawley v. Steele (1877) 6 Ch.D.52l,/a decision on statutory discretion as to use of land) he held this to be a distinct decision that acts which would be wrongful and actionable if done by private individuals are not necessarily actionable when done by a department of the Government for the benefit of the whole community. Simpson J. faced up rather more squarely and accurately to the effect of the wide statutory provision in the Claims Against the Government Act on this public policy approach 
than had Owen J. at first instance. He agreed, on the basis of Farnell's case, that the Act extended the rights of the subject by making the Government liable to be sued in tort, but distinctly subjected the operation of the Act to the rule based on public policy which he had expounded. Whilst there was now liability for tort the door was not wide open; the Government could legitimately claim protection for its "governmental" functions:

"I do not think it [the Claims Against the Government Act] was intended to put the Government in the same position as private persons. If it were, this would amount to submitting to the control of a jury the exercise of various important functions of Government, such as the administration of military matters, of justice, the control and management of prisons, lunatic asylums, public schools etc. Practically this would render the Government departments in these important matters helpless. The Court, it seems to me, must determine on the general law and on the construction of any Acts of Parliament affecting the question, how far the Government is liable for the tort complained of. If it is so liable, then the plaintiff has a right to sue under the Claims Against the Government Act; if it is not so liable, then, in my opinion, the last-mentioned Act does not make it liable." (ibid pp.212-213).

References to this decision have appeared from time to time throughout the Australian reports and it was referred to in respect of purposes or functions peculiar to Government, as recently as 1956 without apparent disapproval - Asiatic Steam Navigation Co. Ltd. v. The Commonwealth (1955-56) 96 C.I.R. 397 at 417 (joint judgment 
of Dixon C.J., McTiernan and Williams JJ.).

An example of the Court's application of its "outrageous use" modification followed shortly after Davidson's case in Evans v. Finn (1904) 4 S.R. (N.S.W.) 297 where a divided Court held the Government liable in respect of bullets flying from a rifle range to the physical danger of nearby residents. The trial Judge, Stephen A.C.J. apparently departed from Davidson on the public policy issue since he directed the jury that if the range could not be used without it being a nuisance, although every reasonable precaution had been taken, the Commonwealth would not be entitled to use it, and would be liable for such nuisance (p.311). This departure is probably not significant, since he apparently forgot the basis on which Davidson's case had proceeded - per Pring J. at p.314 of Evans' case. The Court on a motion for new trial was obviously impressed by the fact that the range could be made perfectly secure by the expenditure of money (p.308 of the report). The judges who made up this Court had taken no part in, and two of them did not refer to, Davidson's case. Pring J. who dissented in Evans' case, accepted and would have applied Davidson's case.

Some endorsement of the limitation on the universal application of statutes subjecting the Crown to liability in tort indicated in Davidson's case is to be found in 
Enever v. The King (1906) 3 C.I.R.969 particularly in the judgment of Barton. J. at pp.987-9. Before referring without disapproval to Davidson's case, Barton J. referred to the justification in Farnell v. Bowman (1887) 12 App. Cas. 643 of the subjection of the Crown to liability in tort because colonial governments embarked on undertakings such as the construction of canals, railways and other works, which elsewhere were left to private enterprise, and said:

"The hardship involved in that maxim [that the King can do no wrong] has resulted in the passing of statutes in several of the States of the Commonwealth dispensing with its operation in relation to matters beyond the ordinary scope of Government, as it was up to recent times understood. But it still remains open to grave doubt how far, if at all, it was intended by those Acts to grant the subject rights of action which in the result would interfere seriously with the ordinary administrative work of the Government as apart from undertakings of the character referred to by the Judicial Committee in the case last cited." (p.988).

There is a further recognition of the limitation by Dixon J. in Field v. Nott (1939) 62 C.I.R.660, an action based on professional negligence by a Crown servant who was officer in charge of a Legal Aid Office:

"The Crown, in right of the State of New South Wales, is liable in tort as well as in contract. But it is one thing to say that the Crown may be sued in tort and it is another to take the principles by which delictual liability between subject and subject is governed and to apply them to the manifold operations of a government acting within an ever-widening conception of the province of the State." (p.673). 
His reservation about the existence of liability seemed, however, in the context of his judgment, to depend more on the factual issue of whether the State had embarked on the activities usually performed by a trader or professional person, than on the application of the same principles to the State, when such functions were found to have been assumed, as applied to private persons - see his judgment at p.676. Evatt $J$. on the other hand was quite prepared to hold the functions to have been assumed and the same principles to apply - see at pp.682, 683.

This suggested limitation on actions against the Crown, based on public policy, was extended in one instance to acts or omissions of those who actually controlled the prison and the operations of prisoners therein - Gibson V. Young (1900) 21 N.S.W.R.7. This was an action brought against the Government under the New South Wales Claims Against the Government Act, in respect of injury to a prisoner caused through the negligence of the gaol officials. It was held that it was against the public interest to allow such an action because the fear of actions would inhibit the discharge of their duty by public officers (p.13 per Darley C.J., and per Cohen J. at pp.17-19). Special weight was put by the Judges on the need to maintain discipline in prisons, it being considered that this would be undermined if prison officers or the Government could be sued for what happened to 
prisoners. It is of interest to note that in U.S. V. Muniz (1963) 374 U.S.150 the Judges were not prepared to make such an assumption. A very strong dissent from the view expressed in Gibson's case has been expressed in Quinn v. Hill [1957] V.R.439, particularly per Smith J. at pp. 447-452 and endorsed by Hudson J. in Hall v. Whatmore [1961] V.R.225, 234 and it seems unlikely that such a line of thought would be followed in any modern decision relating to acts or omissions by a Crown servant resulting in physical harm to the plaintiff. Such cases can be dealt with adequately (as in Quinn's case and Hall's case) by the use of the duty concept and the issue of reasonable care arising from the general principle of Donoghue v. Stevenson.

In a relatively modern instance the view that there may be limits to the right of action against the Crown, other than those arising from the need to base the action squarely on one of the accepted causes of action, necessarily underlay the decision of the High Court. This was Shaw, Savill \& Albion Company v. The Commonwealth (1940) 66 C.I.R.344. In the course of his judgment Dixon J. appears to have expressed the view that the provisions of the Commonwealth Judiciary Act authorise the Court to set the proper bounds of the State's liability in tort. He said that the Act's provisions assumed: 
"that, from the mere statement that the King may be sued in tort, enough appears to enable the Courts to ascertain in the light of the general substantive law what kind of acts or omissions on the part of the servants of the Crown would amount to a civil wrong for which the Treasury would be responsible." (p.358).

In this case the High Court held that an action for negligence brought against the Crown for omissions in the course of planning and executing active naval operations against the enemy must fail because the forces of the Crown were under no duty of care to private individuals. The judgments discuss the inconvenience of trying to apply the ordinary law of negligence in theatres of war, but the ratio of the decision is that, for over-riding reasons of public policy, no action will be allowed against the Crown in such circumstances. Starke J. said at p.356:

"... there is no doubt that the Executive Government and its officers must conduct operations of war... without the control or interference of the courts of law. Acts done in the course of such operations are not justiciable and the courts of law cannot take cognizance of them."

and Dixon J., in a judgment concurred in by two of the other three judges said (at p.362):

"... the law has always recognised that rights of property and of person must give way to the necessities of the defence of the realm ... The uniform tendency of the law has been to concede to the armed forces complete legal freedom of action in the field, that is to say in the course of active operations against the enemy, so that the application of private law by the ordinary courts may end where the active use of arms begins. Consistently with this tendency the civil law of negligence cannot 
attach to active naval operations against the
enemy." Too much weight cannot perhaps be put on this decision in this discussion, since it relates to the very special circumstance that the injury was caused in the course of operations of active war, but there is little real difference in principle between the Court's attitude in this case and that of the Court in Davidson's case. The only issue is what circumstances the Court will feel compel it to adopt this attitude.

By way of contrast with the Shaw, Savill \& Aibion case, no suggestion that there should be relief from liability in respect of governmental functions because of the nature of those functions appears in the most recent decision in which it might have been appropriate (although too much weight cannot be put on this since the tort issue was not raised at trial and appears to have been introduced by the Judges themselves). The general tenor of the judgments, however, suggests that the High Court felt that the approach based on the substantive law as applying between private persons was not inappropriate. The case is that of Administration of Papua and New Guinea v. Leahy (1960-61) 105 C.I.R. where the claim was brought against the Administration in contract, but the judgment contains comments relating to the issues arising in tort. The Claims By And Against The Administration Ordinance 1951 was 
in terms similar to the Commonwealth provisions. The plaintiff had entered into an arrangement with the Administration whereby the latter, in pursuance of its general policy of aiding cattle owners in tick control, would carry out a campaign to eradicate ticks from the plaintiff's cattle. It was held that there was no contract but that the Administration was doing what was properly incidental to carrying out their governmental or departmental function in the conditions prevailing, i.e. pursuing the policy adopted for the eradication of tick. Dixon C.J. indicated that he had given thought to whether the respondent would have had an action in tort for neglect of officers of the Administration which could be vicariously imputed to the Administration, in the course of performing a voluntary service for the plaintiff, the negligent performance of which was likely to occasion damage to the plaintiff. The existence of such an action was negatived, but principally because of lack of evidence of causation. The existence of liability in tort in respect of the neglects alleged was certainly not negatived absolutely. McTiernan $J$. was prepared to accept the possibility of such liability following propositions of Lord GreeneM.R. in Gold v. Essex C.C. [1942] 2 K.B.293 at p.301, but denied it in the instant case on the principle of East Suffolk Rivers Catchment Board v. Kent [1941] A.C.74, the damage being held due to the ticks rather than the inefficient treatment. 
The decision is also of interest because the principle in the East Suffolk case was held by McTiernan and Kitto JJ. to apply to government action although it was not supported by any statutory provision, but rather was done as a matter of policy.

It is apparent that there is a very considerable difficulty facing any Court which is asked to impose a bar based on some undefined public policy on actions in tort against the Crown. The comment of Parke B. in Egerton $v$. Lord Brownlow (1853) 4 H.I.C.I, 123; 10 E.R.359 (a peerage case) states the difficulties:

"Public policy is a vague and unsatisfactory term and calculated to lead to uncertainty and error, when applied to the decision of legal rights; it is capable of being understood in different senses; it may, and does, in its ordinary sense, mean 'political expedience', or that which is best for the common good of the community; and in that sense there may be every variety of opinion, according to education, habits, talents, and dispositions of each person, who is to decide whether an act is against public policy or not. To allow this to be a ground of judicial decision, would lead to the greatest uncertainty and confusion. It is the province of the statesman, and not the lawyer, to discuss, and of the Legislature to determine, what is best for the public good, and to provide for it by proper enactments. It is the province of

- the judge to expound the law only; the written from the statutes: the unwritten or common law from the decisions of our predecessors and of our existing Courts, from text writers of acknowledged authority, and upon the principles to be clearly deduced from them by sound reason and just inference; not to speculate upon what is the best, in his opinion, for the advantage of the community." 
A somewhat similar comment appears in the speech of Iord Haldane I.C. in Vacher v. Iondon Society of Compositors [1913] A.C.107 at 113.

A limitation expressed in general terms, for example in respect of "governmental functions", whether by statute or as a principle developed by the Courts would leave the Courts without any point of reference by recourse to which they could draw the line, and a limitation in general terms might require to be made subject to the "outrageous use" modification of Davidson v. Walker (1901) I S.R. (N.S.W.) 196 or some similar modification if the legislation is to accord with the community's view of what is the proper extent of the Crown's liability. The United States decisions discussed in the next Chapter illustrate the difficulties which such legislative provisions can present. 
CHAPTER III.

Claims against the Federal Government in the United States.

The United States Federal Tort Claims Act (28 U.S. Code s.1346 etc.) presents an example of an endeavour by a Legislature, when allowing tort claims, to define the boundaries of the area within which claims may be brought and to preserve from the jurisdiction of the Courts matters which are thought not properly to be justiciable because of the nature of the governmental action involved. The relevant provisions of the Statute are in the following terms (U.S.Code, 1964 Ed, Vol.7):

s.1346(b) "Subject to the provisions of this Title, the district courts ... shall have exclusive jurisdiction of civil actions on claims against the U.S., for money damages ... for injury ... or loss of property or personal injury or death caused by the negligent or wrongful act or omission of any employee of the Government while acting within the scope of his office or employment, under circumstances where the U.S., if a private person, would be liable to the claimant in accordance with the law of the place where the act or omission occurred.

s.2674. The U.S. shall be liable, respecting the provisions of this Title relating to tort claims in the same manner, and to the same extent as a private individual under like circumstances, but shall not be liable to

- interest prior to judgment or for punitive damages."

To this general provision, thirteen classes of exceptions have been made. The first exception is in the following terms :

s.2680 "The provisions of this chapter ands.1346(b) 
of this Title shall not apply to:

(a) Any claim based upon an act or omission of an employee of the Government, exercising due care, in the execution of a statute or regulation whether or not such statute or regulation be valid, or based upon the exercise or performance or the failure to exercise or perform a discretionary function or duty on the part of a federal agency or an employee of the Government whether or not the discretion involved be abused."

In addition, claims are excepted in respect of loss or negligent miscarriage of mail, the assessment or collection of tax or customs duty or the detention of goods by the customs, admiralty claims, the administration of the Trading with the Enemy Act, the imposition of a quarantine, the fiscal operations of the Treasury or the regulation of the monetary system, combatant military activities in time of war, claims arising in a foreign country, claims arising from the activities of the Tennessee Valley Authority, the Panama Canal Company, a Federal land bank, Federal intermediate credit bank or a bank for co-operatives and claims arising out of assault, false arrest or imprisonment, malicious prosecution or abuse of process, defamation, misrepresentation, deceit or interference with contractual rights.

Actions agrinst the United States are tried by judge alone ( $\mathrm{s} .2402)$ and judgment in an action under s.1346(b) constitutes a complete bar to any action by the same claimant against the government employee whose act or omission gave 
rise to the claim (s.2676).

The relevant definitions are contained in s.2671 which is in the following terms:

"... [I]n s.1346(b) ... of this Title, the term 'Federal agency' includes the executive departments and independent establishment of the United States, and corporations primarily acting as, instrumentalities or agencies of the United States but does not include any contractor with the United States.

'Employee of the Government' includes officers or employees of any federal agency, members of the military or naval forces of the United states, and persons acting on behalf of a federal agency in an official capacity, temporarily or permanently in the service of the United States, whether with or without compensation."

Not unexpectedly, when regard is had to the United States Supreme Court's powers and practice in determining the cases it will hear, there are few decisions of the ultimate tribunal in respect of these provisions and, again not unexpectedly, the decisions relate to the area of special difficulty, namely actions for negligence. An important decision in determining the area of the courts' jurisdiction under thestatute (although later apparently resiled from) was that the statute was a waiver of the Executive's immunity from suit, rather than the creation of new causes of action against the Government. This determination, made in Feres V. U.S. (1950) 340 U.S.135, must surely have restricted the basis on which claims could be made, since it followed from it that the claimant to succeed must show 
a situation in which he could recover damages if his adversary were a private person.

Feres v. U.S. was a decision in respect of three actions against the U.S. for recovery in respect of death or injury resulting from negligence whilst the men injured were on active military duty in the service of the United States. One action related to a faulty heating plant which caused a barracks to catch fire and two related to unskilful medical treatment by Army surgeons.

Jackson J. giving judgment for the Court laid down the proposition that the statute was a waiver of immunity (340 U.S. at 140) and held that it remained for the Courts in the exercise of their jurisdiction to determine whether any claim was recognisable in law (at p.141). Referring to the words in the statute "the U.S. shall be liable ... in the same manner and to the same extent as a private individual under the like circumstances" the Court held that this provision did not create new causes of action but indicated the acceptance of liability in circumstances that would bring private liability into existence (p.141). The view was expressed that this was the same idea as that embodied in the English Crown Proceedings Act 1947 (p.141), but it appears doubtful that this view is entirely accurate - cf. Chapter I and discussions in Chapter IV. 
strictly by requiring an exact private parallel as a basis for State liability. At pp.141/142 of the judgment it was said that

"One obvious shortcoming of these claims is that plaintiffs can point to no liability of a 'private individual' even remotely analagous to that which they are asserting against the U.S. We know of no American law which has ever permitted a soldier to recover for negligence, against either his superior officers or the Government he is serving. Nor is there any liability 'under like circumstances', for no private individual has power to conscript or mobilize a private army with such authorities over persons as the Government vests in echelons of command."

A comparison was drawn with State militias, but to the detriment of plaintiffs' cases. The judgment continued:

"It is true that if we consider relevant only a part of the circumstances and ignore the status of both the wronged and the wrongdoer in these cases we find analagous private liability. In the usual civilian doctor and patient relationship, there is of course a liability for malpractice. And a landlord would undoubtedly be held liable if an injury occurred to a tenant as the result of a negligently maintained heating plant. But the liability assumed by the Government here is that created by 'all the circumstances', not that which a few of the circumstances might create. We find no parallel liability before, and we think no new one has been created by, this Act. Its effect is to waive immunity from recognised causes of action and was not to visit the Government with "novel and unprecedented liabilities."

The actions accordingly failed. It is not clear what is meant to be convyed by writing the phrase "all the circumstances" in quotation marks in the judgment since it is not, as the earlier extract makes clear, the phrase 
used in the statute. There is no note to indicate that it is a quotation from any other source.

This distinction made in Feres appeared in one part of the Court's decision in Dalehite v. U.S. (1953) 346 U.S. 15, an action relating to claims for damages against the United States following the disastrous explosion of ammonium nitrate fertilizer in Texas City in 1947. The fertilizer was produced at the instance, according to the specifications and under the control of the Federal Government for export to increase the food supplies in areas under military occupation following world War II. It had been found that the explosion resulted from the negligence on the part of the Government in adopting the fertilizer export programme as a whole, in its control of various phases of manufacturing, packaging, labelling and shipping the product, in failing to give notice of its dangerous nature to persons handling it and in failing to police its loading on shipboard. No individual acts of negligence were shown and liability was based generally on the actions of the Government agencies in the respects stated.

The majority opinion made passing reference to the provision that liability was to exist "in the same manner and to the same extent as a private individual under the like circumstances" but thereafter turned its attention 
to the discretionary exemption in s.2680(a) of the Title, quoted above. The petitioners had argued that the private analogue provision should prevail, because it was unrealistic

"to say that a program and undertaking and operation, however like it may be to some private corporation or operation such as the manufacture of an explosive, is nevertheless throughout discretionary, if the concept thereof is born in discretion ... Petitioners assert that in the manufacturing ... of FGAN, ... the Government was not charged with any discretionary function or opportunity of discretion, but was charged with the duty of due and reasonable care" (pp.34-35).

The Government's argument in essence was that the provisions of the statute were of equal force and if the instant claim came within one of the exceptions it must fail. This approach to the application of the exception provisions was endorsed by the majority of the Court:

"... these modifications are entitled to a construction that will accomplish their aim, that is, one that will carry out the legislative purpose of allowing suits against the Government for negligence with due regard for the statutory exceptions to that policy. In interpreting the exceptions to the generality of the grant, courts include only those circumstances which are within the words and reason of the exception. They cannot do less since petitioners obtain their 'right to sue from Congress [and they] necessarily must take it subject to such restrictions as have been imposed'. Federal Housing Administration v. Burr 309 U. S.242, 251."

The majority held that on a reading of $\mathrm{s} .2680$ in its entirety the statute was intended to protect the Government from claims in respect of injury, however negligently caused, arising from governmental functions 
(p.32), the division between the majority and the minority on this issue being really as to what was within this protection. The plaintiffs as a culmination of their argument that to protect all discretionary decisions regardless of the nature of the undertaking to which they related was too narrow, had sought to restrict the statutory exemption (at least in cases directly analagous to those involving private manufacturers) to discretions at high executive and legislative levels (pp.34, 35). The majority did not accept this approach and applied the discretionary exemption, regardless of the nature of the function:

"It is unnecessary to define, apart from this case, precisely where discretion ends. It is enough to hold, as we do, that the "discretionary function or duty" that cannot form a basis for suit under the Tort Claims Act includes more than the initiation of programs and activities. It also includes determinations made by executives or administrators in establishing plans, specifications or schedules of operations. Where there is room for policy judgment and decision there is discretion. It necessarily follows that acts of subordinates in carrying out the operations of government in accordance with official discretions cannot be actionable. If it were not so, the protection of $\mathrm{s} .2680$ (a) would fail at the time it would be needed, that is when a subordinate performs or fails to perform a causal step, each action or non-action being directed by the superior, exercising, perhaps abusing, discretion." (pp.35,36).

The majority held that specific matters such as the fixing of bagging temperatures, the type of bagging, the 
labelling and the determination of details of manufacture were periormed under direction of a plan developed at high level under a direct delegation of plan making authority (p.40). They were responsibly decided at a planning rather than operational level and involved considerations more or less important to the practicability of the Government's fertilizer program (p.42). As such they were "judgments of the best course [in] the discretion of the executive or administrator" (p.34) and as such not actionable $(p .42)$. So also was the alleged failure to prevent fire by regulating storage or loading in a different fashion (p.43). The Feres approach was adopted in respect of allegations relating to alleged failures in fighting the fire because failure or carelessness of public firemen did not in the general United States law create private actionable rights (p.43).

It appears to be implicit in the majority's opinion that, apart from the "governmental functions" issue referred to briefly at p.32 of the judgment, if a departure by an individual state servant from the norms laid down by the planning authority could have been shown liability might have been established. This would have been failure in an "operational" and not in a "discretionary" matter.

The dissenting Justices took a different approach, and it is interesting, in light of the discussion on the 
Australian and New Zealand materials, to see how the factor of the State engaging in commercial-type activities was used as a liberalising factor, instead of a restricting one, in construing a statute which contained specific restrictions. The minority opinion first considered whether a private person would be liable in the circumstances and held that such liability would exist having regard particularly to the dangerous nature of the substance concerned (p.57). Such liability would be held directly without regard to vicarious liability for the torts of servants. Turning to the discretionary issue the minority did not suggest that liability could be based only on decisions at Cabinet or similar level, but did suggest that there was a limit to the levels at which the decisions were discretionary planning ones. Thus protection would be allowed for the decision to institute programmes but not for planning in detail, even though this might involve the balancing of care against cost, of safety against production or of warning against silence (p.58).

Both opinions referred to the legislative history of the statute and particularly to an explanation of the discretionary exclusion in the following terms:

"The first subsection of section 402 exempts from the bill claims based upon the performance or non-performance of discretionary functions or duties on the part of a Federal agency or Government employee, whether or not the discretion involved be abused, and claims based upon the act or omission of a Government 
employee exercising due care in the execution of a statute or regulation, whether or not valid. This is a highly important exception, intended to preclude any possibility that the bill might be construed to authorise suit for damages against the Government growing out of an authorized activity, such as a flood-control or irrigation project, where no negligence on the part of any Government agent is shown, and the only ground for suit is the contention that the same conduct by a private individual would be tortious, or that the statute or regulation authorizing the project was invalid. It is also designed to preclude application of the bill to a claim against a regulatory agency, such as the Federal Trade Commission or the Securities and Exchange Commission, based upon an alleged abuse of discretionary authority by an officer or employee, whether or not negligence is alleged to have been involved. To take another example, claims based upon an allegedly negligent exercise by the Treasury Department of the black-listing or freezing powers are also intended to be excepted. The bill is not intended to authorize a suit for damages to test the validity of or provide a remedy on account of such discretionary acts even though negligently performed and involving an abuse of discretion. Nor is it desirable or intended that the constitutionality of legislation, or the legality of a rule or regulation should be tested through the medium of a damage suit for tort. However, the common-law torts of employees of regulatory agencies would be included within the scope of the bill to the same extent as torts of nonregulatory agencies. Thus, section 402(5) and (10), exempting claims arising from the administration of the Trading With the Enemy Act or the fiscal operations of the Treasury, are not intended to exclude such common-law torts as an automobile collision caused by the negligence of an employee of the Treasury Department or other Federal agency administering those functions." (p.29,n.).

The majority had taken the repetition of these sentiments in a number of Congressional Committee reports 
on the proposed tort claims legislation to indicate that Congress desired to waive the Government's immunity from actions for injuries to person and property occasioned by the tortious conduct of its agents acting within the scope of business, but that it was not contemplated that the Government should be subject to liability arising from acts of a governmental nature or function ( $\mathrm{pp} .27,28$ ), or from the exercise of discretion. The minority however took the view that the intention was that prime importance should attach to the nature of the operation from which the claim arose. Thus:

"We think that the statutory language... point[s] to a useful and proper distinction preserved by the statute other than that urged by the Government. When an official exerts governmental authority in a manner which legally binds one or many, he is acting in a way in which no private person could. Such activities do and are designed to affect, often deleteriously, the affairs of individuals, but courts have long recognised the public policy that such official shall be controlled solely by the statutory or administrative mandate and not by the added threat of private damage suits." (p.59).

Thus the minority as an alternative basis for holding the Government liable would have restricted the discretionary exclusion wholly to that type of discretion which government agencies exclusively exercise in regulating private individuals (p.58 n.l2), although such an interpretation would appear to make the provision excepting discretionary acts redundant. 
Taking this view, the minority would have applied their commercial functions distinction to exclude such functions entirely from the discretionary exemption and to include them within the waiver of liability of the general provision. Thus following the passage from p.59 cited above the minority said (at pp.59-60):

"The official's act might inflict just as great an injury and might be just as wrong as that of the private person, but the official is not answerable. The exception clause of the Tort Claims Act protects the public treasury where the common law would protect the purse of the acting public official.

But many acts of government officials deal only with the housekeeping side of federal activities. The Government, as landowner, as manufacturer, as shipper, as warehouseman, as shipowner and operator, is carrying on activities indistinguishable from those performed by private persons. In this area, there is no good reason to stretch the legislative text to immunize the Government or its officers from responsibility for their acts, if done without appropriate care for the safety of others. Many official decisions even in this area may involve a nice balancing of various considerations, but this is the same kind of balancing which citizens do at their peril and we think it is not within the exception of the statute.

The Government's negligence here was not in policy decisions of a regulatory or governmental nature, but involved actions akin to those of a private manufacturer, contractor or shipper. Reading the discretionary exception as we do, in a way both workable and faithful to legislative intent, we would hold that the Government was liable under these circumstances."

In the next case argued, Indian Towing Co. Inc. V. 
sought the best of both worlds - to accept the discretionary/operational distinction implicit in the opinions in Dalehite, but to marry with it and apply to "operational" functions the protection of "governmental" functions accepted even by the minority in Dalehite and the protection of governmental activities applied by the Court in Feres, where liability was denied because no exact parallel could be found in private law for the liability sought to be placed on the Government. It is apparent from consideration of Dalehite and Feres that the protection of governmental activities proceeded on a different basis in each case and was related in each case to different provisions of the Act. In Dalehite the inherent nature of the activity attracted protection whereas in Feres it was based on the special relationship between the plaintiff and the Government. The action in Indian Towing Co. was based on allegations of negligence on the part of the Coast Guard officers in allowing a navigation light to be extinguished as a result of which a vessel was stranded with consequent damage to cargo. The judsment of the majority proceeded on the basis that the "operational level" of activity was involved (by implication, once the Government had elected to undertake the lighthouse service $(\mathrm{p} .69))$ in the action so that the protection of discretionary activity in $\mathbf{S} .2680(a)$ would not apply. 
general waiver provision "in the same manner and to the same extent as a private individual under like circumstances" excluded liability in the performance of activities which private persons do not perform (which were equated with "uniquely govermental functions"). The majority adopted the second approach of the minority in Dalehite by considering the nature of the activity as a whole, and allowed liability not only when an exact parallel could be drawn between Government and private activity, but also where a parallel could be drawn if private persons were permitted to undertake the same activity $(p p \cdot 66,67)$. This approach was based on the fact that the words in the statute were "under like circumstances", and not "under the same circumstances" (p.64).

The Government to some extent fell between two stools because it did not seek immunity in respect of all actions furthering "uniquely governmental" activity but endeavoured to do so for the failure to perform the end objective of such activity $(p .66)$. The argument - also ran up against the difficulty epitomised by Latham C.J. in South Australia v. The Commonwealth (1942) 65 C.I.R.373, 423 in defining what was "governmental activity". The majority in Indian Towing Co., like the minority in Dalehite, did not accept that an 
performed by the Government. Thus the majority would allow liability for negligence in the conduct of governmental activities at operational level, if a private person would be liable if he could perform the same activity $(\mathrm{pp} .68,69)$.

Four dissenting Justices applied the ruling in Feres as accepted in respect of fire fighting in Dalehite and would have excluded liability because there was in the United States no parallel liability between a non-governmental agency and a private person (p.75). This approach was based on the provision that the Government was liable in instances where it would be suable "if a private person" $(p .75)$.

That the majority should feel able to depart from the principle accepted in Feres without over-ruling that decision is not difficult to comprehend since Feres related to the limitation on the right to sue arising from the particular status of servicemen, but the shift from requiring an exact parallel between private parties to the application of general principles as drawn from analagous (though not presently existing) situations between private parties appeared to throw open to the decision of the Courts the bounds of the area of government liability. This situation was deprecated by the minority which held to the effect of waiver indicated in Feres saying: 


\begin{abstract}
"In Feres the Court was of the view that the Act does not create new causes of action theretofore beyond the applicable law of torts. So in determining whether an action for negligence in maintaining public lights is permissible, we must consider whether similar actions were allowed ... prior to the Tort Claims Act, against public bodies otherwise subject to suit." $(\mathrm{p} .73)$.
\end{abstract}

and

"If Congress intended to create liability for all incidents not theretofore actionable against suable public agencies, that intention should be made plain. The courts are not the legislative branch of the Government." (p.75).

In the next decision on the ict, Rayonier Inc. $v$. U.S. (1957) 352 U.S.315, the Court appears in a short judgment to have completed the reversal of its decision as to the effect of the statute as a waiver of immuity expressed in Feres, and to have opened the way completely, in respect of operational activities, to judicial legislation as to liability, by declining to accept as a boundary the distinction between proprietary and "uniquely governmental" acts or to draw parallels from cases involving other suable public agencies.(p.319). The claim was for damages in respect of negligence of employees of the United States in allowing a forest fire to be started on Government land and in failing to act with due care to put the fire out. The fire started when sparks from a railway locomotive fell into highly inflamable dry grass and bush which had been allowed to accumulate on Government-owned land, and had been allowed to smoulder on when 
it could have been completely extinguished. The Supreme Court decision turned on this failure to extinguish the fire. In the part of the decision which reflected on Feres the Court said:

"It may be that it is 'novel and unprecedented. to hold the United States accountable for the negligence of its firefighters, but the very purpose of the Tort. Claims Act was to waive the Government's traditional all-encompassing imnunity from tort actions and to establish novel and unprecedented governmental liability." $(\mathrm{p} .319)$.

The Court justified this wide approach, and indeed every wide approach to governmental liability and review of governmental action by Courts, by accepting a lossdistribution theory. The Government's argument had been supported by the potentially enormous liability if the door was opened wide to claims based on the originating and spread of fire:

"The Government warns that if it is held responsible for the negligence of Forest Service firemen a heavy burden may be imposed on the public treasury ... But ... Congress, believing it to be in the best interest of the nation saw fit to impose such liability on the United States in the Tort Claims Act. Congress was aware that when losses caused by such negligence are charged against the public treasury they are in effect spread among all those who contribute financially to the support of the Govermment and the resulting burden on each taxpayer is relatively slight. But when the entire burden falls on the injured party it may leave him destitute or grievously harmed. Congress could, and apparently did, decide that this would be unfair when the public as a whole benefits from the services performed by Government employees." (pp.319-320). 
In the final decision to be considered, U.S. v. Muniz (1963)374 U.S.150\%, the Supreme Court further considered the decision in Feres $v$. U.S. and the wider approach developed in Indian Towing Co. V. U.S. and Rayonier Inc. V. U.S. The issue for determination was whether an action could be brought under the ict to recover damages from the United States Government for personal injuries sustained by reason of the negligence of a government employee during the plaintiff's confinement in a federal prison. The argument arose in respect of two actions. In the first a prisoner who suffered from a benign brain tumour alleged that he was not given proper medical treatment and became blind as a result of this neglect, and in the second the prisoner was attacked and injured by other inmates, allegedly as a result of prison officials' negligence in failing to provide enough guaras to prevent the assault and in letting prisoners, some of whom were mentally abnormal, mingle without adequate supervision.

The Government contended, inter alia, (374 U.S. at 159) that the decision in Feres V. U.S. determined the matter, on the ground that there was no analagous private liability. In considering this issue the Court was faced with the situation that in some states such claims were permitted, whereas in others they were not. The Court held the effect of Feres V. U.S. to be confined to the special situation of military personnel (374 U.S. at 162) 
and resolved the private analogue problem presented by the differences in State law, really by applying the decision in Rayonier $v$. U.S. that the Act applied to novel and unprecedented forms of liability as well as to analagous private forms of liability. The Court's decision in Muniz was supported by the fact that analagous liability existed in some States, but the judgment said of the State provisions denying the right of action

"Such cases should not be persuasive ... We think it improper to limit suits by federal prisoners because of restrictive state rules of immunity .... The Federal Tort Claims Act provides much needed relief to those suffering injury from the negligence of government employees. We should not, at the same time that State courts are striving to mitigate the hardships caused by sovereign imunity, narrow the remedies provided by Congress." (374 U.N. at 165).

In addition the Court discussed and dismissed the problems of disparity of standards and non-uniform rights of recovery arising from differing state laws, and dismissed from consideration as unproven, suggestions that prison discipline might be impaired if the Act was construed so as to allow claims by federal prisoners.

- The right in the circumstances to bring an action under the Act was upheld, subject to determination under the relevant State law of the issue whether there had been negligence (374 U.N. at 150 and 162).

The effect of these decisions and the shifts in the 
88.

Court's approach can perhaps best be seen by a tabulated presentation of the lecisions:

1. In Feres (where particular emphasis was put on the private analogue provisions of $\mathrm{s} .1346(\mathrm{~b}))$ :

(a) the statute was a waiver of immunity in. situations where liability would exist between private persons, and not a creation of new rights of action;

(b) although liability would exist in the given situation between private persons, it would not exist where the relationship of the plaintiff to the United States had no counterpart as between private persons.

2. In Dalehite (where emphasis was on the effect of the exclusion provisions of $\mathrm{s} .2680$ ) (majority): the statute was designed to protect the Government (a) from all claims in respect of governmental functions; and

(b) in respect of matters of whatever character where a discretionary function or duty was exercised, but not in respect of matters where there was mistake or fault in carrying out what had been decided; and

(c) from all liability if in an action against a public authority other than the Government there would be no liability. 
(minority):

the statute was designed to protect the Government only

(a) against claims in respect of governmental

functions of a regulatory or legislative character and not where the government was performing functions which private persons also performed or functions analagous thereto; and

(b) in respect of discretionary functions at the level where Government programes were originated, but not in respect of subsequent decisions, and not where the undertaking was analagous to that of a private person.

3. In Indian Towing Co. (majority):

the statute permitted claims in respect of "operational" activities whenever an exact parallel could be drawn with the activities of private persons, or where private persons wolld be held liable if they could conduct such activities, elected to do so and did so negligently; by implication, that activities in such cases were "operational" and not discretionary once the decision to undertake the activity was made. (minority);

the statute was intended to allow actions in the operational field only where a parallel liability 
existed in respect of private parties.

4. In Rayonier Inc. (majority):

that the purpose of the statute was to establis: causes of action against the Government which previously did not exist and that the test of liability in the statute was not whether other public authorities would be liable in the same circumstances but whether a private person would be. (minority):

the test was the liability of other governmenta authorities.

5. In Nuniz:

that any differences between the laws of States as to whether private analagous actions would be allowed were to be resolved in favour of the plaintiff, particularly if no strong reason for providing protection to the Government was shown. From this it appears that the final view of the Supreme Court is largely that of the minority in Dalehite, namely that the Government is protected from claims in respect of functions which are regulatory or otherwise legislative in character, legally binding one or many, and whether or not involving loss to individuals; also in respect of the decision to undertake programmes or not to 
do so, and perhaps in respect of true policy decisions as to the conduct of activities; but that the government will be liable for all tortious acts or omissions of any other character and at any other level if private individuals. able, and electing, to do the same thing would be liable, and this notwithstanding that private individuals are not in fact able in the usual course to do such things.

Cases which have been decided in United States Courts below the Supreme Court indicate the wide area within which problems may arise when the tort remedy is used to obtain recompense for governmental action causing detriment to the individual. The variety of situations which may arise may be imagined from a consideration of the ramifications of government activity, but the sumary of cases to be found in the American Annotated Law Reports (99 AIR 2d 1011 et seq.) presents a good survey. Thus claims may arise in respect of the nature of the undertaking or its operation in the construction and maintenance of public property, the launching of prosecutions or the release of information about crime investigation, the seizure or detention of property, the operation of prisons and the committal of persons thereto, the operation of hospitals and other health services, including the care and detention of the insane, the maintenance and operation of lighthouses and aviation navigational aids, the charting, 
marking and removal of maritime hazards, air traffic control, the supply of meteorological information, the preservation and control of wildlife and related operations. housing development, the issue or refusal of permits, licences, clearances and the like, agricultural experiments. the result of government searches or researches, e.g. geological surveys, audit matters, the releasing of information supplied to government agencies by individuals or of information detrimental to individuals or acted upon by individuals to their detriment. So also, should the state be exposed to suit in respect of zoning powers which may reduce the value of property, the prohibition of sale of harmful drugs, interest or rate fixing decisions, the enforcement of anti-trust laws or the failure to do so, issuing passports, or for omissions in respect of a responsibility which the State has to some uncertain extent assumed? (Davis, Aảministrative Law Treatise (1958) Vol.3 sections 25.11 and 25.14).

Even more difficult than the problems presented by detriments resulting irom Government action in such spheres as those described may be the problems resulting from Government inaction or limited action by the Government. The allowing of a tort remedy when the Government has acted may present difficulties in respect of the Court's competence to review the matter and the total cost of 
providing a remedy to those affected, but both these difficulties are multiplied if the issue is opened to review whether the Government should have acted in a particular sphere or whether it should have gone further in respect of a responsibility which has to some extent been assumed (cf. Davis, op.cit., Vol.3 s.25.14).

The decisions of the supreme Court discussed in this Chapter illustrate the difficulties with which the Courts are faced when the test of all Government tort liability is expressed in terms of a private analogue although the activity to be judged may have no private counterpart, and demonstrate that such a test leaves room for creative interpretation by the Courts. Should the complete private analogue approach of Eeres v. U.S. be adopted, the difficulties in the application of the statute largely disappear, but in such case the final comment of the minority in Dalehite v. U.S. (1953) 346 U.S. at p.60 would appear completely justified:

"Surely a statute so long debated was meant to embrace more than traffic accidents. If not, the ancient and discredited doctrine that 'The King can do no wrong' has not been uprooted; - it has merely been amended to read, 'The King can do only little wrongs'."

That the legislature has attempted more precisely to delineate the areas within which claims may be made, by defining areas within which they may not be made, does not appear to alleviate these difficulties where the two 
provisions may be applied to the same circumstances.

By way of caution, it must be suggested that conclusions as to the meaning and effect of the statute as a whole which the United States Supreme Court eventually appears to have reached might not be those which a New Zealand Court would reach if the United States' provisions were translated in their present form to our statute. Regard must be paid to the American Court's approach to the interpretation of the statute, which is subtly different from that of our own Courts. The United States practice provides a wider and richer range of material upon which to draw as a basis for interpretation (see e.g. the decision and footnotes in Dalehite v. U.S. (1953) 346 U.S. 15) and as a result the court construes the statute at least in part on the basis of its legislative history. In our own Courts construction would be based on a detailed analytical examination of the wording and structure of the statute, the application of rules of construction, and ultimately on the Courts' view of what interpretation best accorded with the public benefit - cf. Maxwell on Inter retation of Statutes, $11 \mathrm{Ed}$. (1962) p.2. 
CHAPTER IV:

Fersonal liabilities in tort of Crown servants and public officers.

1. Introductory:

Since one of the devices presently used in the United Kingdom and New Zealand and the only device used in Victoria for subjecting the Crown to liability in tort is to make the Crown vicariously liable for the torts of its servants, it is important, in order to perceive the full extent of the Crown's liability, to consider in what circumstances the servant will be held to have been guilty of a tort in respect of his official acts. It is not proposed to discuss activities which have an exact counterpart in the everyday life of every citizen e.g. driving a Government motor vehicle, because these situations present no difficulty either in the determination of what conduct is tortious or in the decision whether a tort action should be allowed against the state in respect of them. The

- difficult area is that of the official or apparenty official act.

Whether an official decision is open to review either by way of appeal to some superior tribunal or authority or by the Courts using the prerogative writs or the remedy of declaration is a matter outside the scope of this thesis and it may well be that some of the cases considered in relation to the availability of a tort remedy could be 
open to such review - cf. Professor de Smith's comments on Partridge v. General Medical Council in Judicial Review of Administrative Action (1959) p.202(n). The availability of other remedies is of importance, however, in any consideration of what remedy in tort ought to be available and is referred to in that context in Chapter VI. The right to sue personally Crown servants or the servants of public authorities in tort is one of long standing, and at least in the case of Crown servants has been expressed to be the factor which made the immunity of the Crown from suit other than insupportable; Rogers $v$. Rajendro Dutt (1860) 13 Moo.P.C.C.209, 236; 15 E.R.78. The Courts have however been to some degree selective as to the classes of servants against whom actions would be allowed and as to the circumstances in which liability would arise. The decisions appear to have gone some way towards working out the basis of a governmental law of tort referred to in the Introduction. In this respect we are in a different situation from the Americans and it is worth looking briefly at the reasoning behind, and possible drawbacks to, their approach as a background to the decisions which are authoritative in our own courts. 
2. The United States law:

A.s has been indicated in the last Chapter, the exclusion provision in the Federal Tort Claims Act seems to have removed any possibility of the Government being sued in respect of discretionary decisions made in the course of regulatory functions and the trend in the Courts' decisions has been to give officials personal immunity from suit in respect of official acts, other than the failure to perform ministerial duties: cf. Davis, Administrative Law Treatise (1958) Vol.3, p.507; Schwartz: Introduction to American Administrative Law, $2 \mathrm{Ed}$. (1962) p.220; Gellhorn and Byse: Administrative Law, 4 Ed. (1960) p.360 et seq.; Jaffe: Judicial Control of Administrative Action (1965) pp.240-247. (chicuetion)

Judges are exempt from liability to civil suits for judicial acts within their jurisdiction, even if there is irregularity or error in the exercise of the jurisdiction, and whatever the motives with which the act is done. The immunity is intended to serve the public good by leaving the judicial officer free to act upon his own convictions, without apprehension of personal consequences to himself in discharging his functions, and to prevent vexatious litigation (Gellhorn and Byse, op.cit., pp.362-3). This immunity has been extended to officers of Government departments whose duties are related to the judicial 
process (e.g. prosecutors), to Cabinet Ministers: Spalding

v. Vilas (1896) 161 U.\$.483, and to those involved in the processes of arrest and detention under enemy alien

legislation: Gregoire v. Biddle (1949) 177 F. 2d. 579

(United States Court of Appeals), and to "political" and

"administrative" officers generally: Jaffe, op.cit. p.242.

The reasoning behind the extension of immunity was

expressed thus in Gregoire v. Biddle by Chief Judge Iearned

Hand:

"It does indeed go without saying that an official, who is in fact guilty of using his powers to vent his spleen upon others, or for any other personal motive not connected with the public good, should not escape liability for the injuries he may so cause; and, if it were possible in practice to confine such complaints tc the guilty, it would be monstrous to deny recovery. The justification for doing so is that it is impossible to know whether the claim is well founded until the case has been tried, and that to submit all officials, the innocent as well as the guilty, to the burden of a trial and to the inevitable danger of its outcome, would dampen the ardour of all but the most resolute, or the most irresponsible, in the unflinching discharge of their duties. Again and again the public interest calls for action which may turn out to be founded on a mistake, in the face of which an official may later find himself hard put to it to satisfy a jury of his good faith. There must indeed be a means of punishing public officers who have been truant to their duties; but that is quite another matter from exposin such as have been honestly mistaken to suit by anyone who has suffered from their errors. As is so often the case, the answer must be found in a balance between the evils inevitable in either alternative. In this instance it has been thought in the end better to leave unredressed the wrongs done by dishonest officers than to subject those who try to do their duty to the 
constant dread of retaliation ..."

The issue of officials' immunity from suit came before the Supreme Court in Barr v. Matteo (1959) 360 U.S.564, an action for defamation against a federal officer. Immunity from suit was upheld by a divided Court holding that the officer's statement was absolutely privileged. The action was brought against the Director of a Government agency following his dismissal of the plaintiffs, who were subordinate officials of the agency, and the issue by him of a press release blaming the plaintiffs for a course of action which had been strongly criticised by Congress. The press release had been held at trial to be defamatory and the defendant to have issued it maliciously or without reasonable belief of its truth, findings which would have defeated any qualified privilege. Six members of the Supreme Court were agreed that there was an absolute privilege, the reasons for its recognition being substantially those set out in the extract from Gregoire v. Biddle above, although one, Mr Justice Stewart, dissented on the issue of whether the defendant was acting "in the line of duty" and therefore within the shield so established. The immunity, previously established in respect of Cabinet Ministers by Spalding v. Vilas (supra), was extended to those exercising discretions as "policy-making executive" officials. 
The other dissenting Justices, Chief Justice Warren, Nir Justice Douglas and Mr Justice Brennan were dissatisfied with the "complete annihilation" of the plaintiffs' interest by the majority's view. In a joint judgment, the Chief Justice and Mr Justice Douglas indicated that absolute privilege was proper for internal communications and for communications by Ministers, on the basis of the considerations which led to the decision in Chatterton $v$. Secretary of State for India [1895] 2 Q.B.189, or, in respect of Ministers, because they partook of Presidential immunity. In respect of other officers, however, they regarded qualified privilege as sufficient, both because it placed on an equal footing the activities of the citizen criticising the Government and of government officers replying, and because it enabled other interests to be balanced - the right to criticise Government and officials with the right of Goverment and officials to reply. Absolute immunity, it was suggested, would give the Government and its officials such an advantage in replying to criticism that criticism itself would be stifled.

Mr Justice Brennan, in a separate dissent, also regarded qualified privilege as sufficient to achieve what was necessary to preserve the efficient functioning of Government. This would protect tle official against the consequences of honest mistakes, which was all he could properly claim. In his view, the majority's opinion 
proceeded on the basis "simply that there are certain societal interests in relieving federal officials from judicial inquiry into their motives that outweigh all interest in affording relief", and as to this approach, Mr Justice Brennan said:

"In the first place, Proiessors Harper and James have, I think, squarely met and refuted that argument on its own terms: 'Where the charge is one of honest mistake we exempt the officer because we deem that an actual holding of liability would have worse consequences than the possibility of an actual mistake (which under the circumstances we are willing to condone). But it is stretching the argument pretty far to say that the mere inquiry into malice would have worse consequences than the possibility of actual malice (which we would not, for a minute, condone). Since the danger that official power will be abused is greatest where motives are improper, the balance here may well swing: the other way'. Harper \& James, Torts (1956), p.1645. And in the second place, the courts should be wary of any argument based on the fear that subjecting government officers to the nuisance of litigation and the uncertainties of its outcome may put an undue burden on the conduct of the public business. Such a burden is hardly one peculiar to public officers; citizens generally go through life subject to the risk that they may, though in the right, be subject to litigation and the possibility of a miscarriage of justice. It is one of the goals of a well-operating legal system to keep the burden of litigation and the risks of such miscarriages to a minimum

Mr Justice Brennan, after considering some of the means available to prevent vexatious litigation or the imposition of too great a liability on State officers, continued with the comment which provides a general warning 
in respect of any approach to Government tort liability:

"... the way to minimizing the burdens of litigation does not generally lie through the abolition of a right of redress for an admitted wrong. The method has too much of the flavour of throwing out the baby with the bath - today's sweeping solution insures that Government officials of high and low rank will not be involved in litigation over their allegedly defamatory statements, but it achieves this at the cost of letting the citizen who is defamed even with the worst motives go without remedy."

As to the considerations to which the majority accorded decisive weight in reaching their answer on the balancing of societal interests, Mr Justice Brennan had doubts about the extent to which the fear of litigation in fact inhibited officials in the execution of their duties and as to whether it was necessarily a bad thing that it should do so; whether supervision by an administrator's superiors would be effective in assuring that there would be little abuse of a freedom from suit and whether absolute immunity would not in fact be severely abused. Coupled with these doubts were the persuasive considerations that the beneficial result sought to be achieved by the majority's decision might be as satisfactorily obtained, without barring the injured citizen's remedy, by providing government representation for the officer named as defendant in such suits, by the State indemnifying officers in respect of judgments rendered against them or simply by a statutory enactment eliminating the officer as a party to 


\section{3.}

such suits and making the Government suable instead.

3. Personal liability of Crown servants (General):

That the English law does not offer the official any immunity because of his status has been clearly laid down. The report of Nostyn v. Fabrigas (1774) I Cowp.161; 98 E.R. 1021 is concerned largely with the question whether the Court in England had jurisdiction in respect of a tort committed in Ninorca, but Lord Nansfield emphatically stated the right to sue a servant or officer of the Crown in respect of tortious acts committed by him in the course of his official duties. The action was against the Governor of Minorca for assault and false imprisonment. To the argument that the Governor could not be sued, Iord Nansfield said that

"it has been insisted by way of a distinction, that supposin an action will lie for an injury of this kind committed by one individual against another, in a country beyond the seas, but within the dominion of the Crown of England, yet it shall not emphatically lie against the Governor. In answer to which I say, that for many reasons, if it did not

- lie against any other man, it shall most emphatically lie against the Governor." (p.172).

In the course of this judgment reference was made also to cases in which damages had been awarded against naval officers for the destruction of buildings for reasons of policy, although it appears that the defendants were 
indemnified by the Crown in respect of the awards. Similarly it was indicated in Tobin V. R. (1864) 16 C.B. (N.S.) 310; 143 E.R.1148, that any such action lay against the wrongdoing Crown servant ( $\mathrm{pp} .347,360)$. In that action, where it was sought to make the Crown liable for the wrongful acts of the Naval officer concerned, a distinction was drawn between actions done by command of the Crown and actions in performance of an Act of Parliament, the Crown being held free from liability in the latter circumstances because the officer was not acting as agent of the Crown; a proposition which has only now retained viability in such cases as Enever v. The King (1906) 3 C.I.R.969; cf. A.G. for N.S.W. V. Perpetual Trustee Co.Ita. (1951-52) 85 C.I.R.237, 251, and which has been finally disposed of in New Zealand by s.6(3) of the Crown Proceedings Act 1950. A further proposition in this decision, which will be considered later, was that even if the officer had authority from the Crown to seize ships engaged in the slave trade, so that seizure if lawful would have been made as agent for the Crown, if the ship seized was not in fact engaged in the slave trade the officer would not act within the scope of his authority and would not make his principal liable for the wrong.

This general proposition that a government servant would be personally liable for tortious acts done in respect 
of his official business is clearly laid down in Rogers $v$.

Rajandro Dutt (1860) 13 Moo.P.C.C.209; 15 E.R.78 a claim

in respect of interference with trade. There Dr

Iushington said:

"it does not appear to their Iordships material to consider whether the demand made on the part of the plaintiffs was exorbitant or not, nor whether the opinion expressed by the defendant, and on which he subsequently acted, was founded in good policy, or otherwise. Neither does it seem to them to conclude the question in the action, that the act complained of is to be considered as the act of the Government, and that in the part which the defendant took in it he acted only as the officer of the Government, intending to discharge his duty as a public servant with perfect good faith, and with an entire absence of any malice, particular or general, against the plaintiffs. For if the act which he did was in itself wrongful, as against the plaintiffs, and produced damage to them, they must have the same remedy by action against the doer, whether the act was his own, spontaneous and unauthorised, or whether it were done by the order of the superior power ... [I]t is hard on [the] agent when this obligation [of the Government to indemnify him] is not satisfied; but the right to compensation in the party injured is paramount to this consideration. Neither in the case of damage occasioned by a wrongful act, that is, an act which the law esteems an injury, is malice a necessary ingredient to the maintenance of the action; an imprisonment of the person, a battery, a trespass on land, are instances, and. only instances, in which the act may be quite innocent, even laudable, as to the intention of the doer, and yet, if any damage, even in legal contemplation, be the consequence, an action will

- Iie." (p.236).

The term "malice" appears in a number of the decisions to be referred to, and it is perhaps useful to interpolate here a brief indication of the senses in which 
the Courts use the term. Salmond on Torts 14 Ed. (1965) contains the following statement at pp.24-25:

"The term malice, as used in law is ambiguous, and possesses two distinct meanings which require to be carefully distinguished. It signifies either (1) the intentional doing of a wrongful act, without just cause or excuse; or (2) action determined by an improper motive. To act maliciously means sometimes to do the act intentionally, while at other times it means to do the act from some wrong and improper motive, some motive of which the law disapproves. This motive need not be that of spite or ill-will that is to say, it need not amount to malice in the narrow and popular sense of the term. Any motive is malicious in the second sense which is not recognised by law as a sufficient and proper one for the act in question."

The learned editor of this edition of Salmond on Torts suggests that the use of the term in its first, technical, sense is mere verbiage which befogs the issue: the matter of importance is the legal characteristics of the act in issue (ibid p.25). In the second sense he suggests malice is relevant in a few torts, viz. malicious prosecution, nuisance, conspiracy, injurious falsehood and defamation and in the assessment of damages in other cases (ibid p.26) but

"[S]ave in such exceptional cases malice in the sense of improper motive is entirely irrelevant in the law of torts. The law in general asks merely what the defendant has done, not why he did it. A good motive is no justification for an act otherwise illegal, and a bad motive does not make wrongful an act otherwise legal. The rule is based partly on the danger of allowing such a tribunal as a jury to determine the liability of a defendant by reference to their own opinions and prejudices as to the propriety of his motives, and partly on the difficulty of 
ascertaining what those motives really were: Allen V. Flood [1898] A.C.1, 118-119, 153". (ibid p.26).

To return to the general issue, not only was the proposition of the servant's liability repeated in Feather V.R. (1865) 6 B. \& S.257; 122 E.R.1191 by Cockburn C.J., Crompton, Blackburn and Mellor JJ. but again the proposition was clearly expressed that the officer could claim no protection because he was engaged in Crown business. In the judgment of the Court, Cockburn C.J. said, at p.296:

"Let it not be supposed that a subject sustaining a legal wrong at the hands of a Minister of the Crown is without a remedy. As the Sovereign cannot authorise wrong to be done, the authority of the Crown would afford no defence to an action brought for an illegal act comitted by an officer of the Crown. The learned counsel for the suppliant rested part of his argument on the ground that there could be no remedy by action against an officer of state for an injury done by the authority of the Crown, but he altogether failed to make good that position ... $[A] n$ action will lie for a tortious act notwithstanding it may have had the sanction of the highest authority in the state ... In our opinion no authority is needed to establish that a servant of the Crown is responsible in law for a tortious act done to a fellow subject, though done by the authority of the Crown - a position which appears to us to rest on principles which are too well settled to admit of question, and which are alike essential to uphold the dignity of the Crown on the one hand, and the rights and liberties of the subject on the other."

See also Johnstone v. Pedlar [1921] A.C.262 per Viscount Finlay at 271. The general principles contained in these 
decisions were shortly epitomised by Romer J. in Raleigh

v. Goschen [1898] I Ch.73 at 77 thus:

"... if any person commits a trespass ( $I$ use that word advisedly as meaning a wrongful act or one not justifiable), he cannot escape liability for the offence, he cannot prevent himself being sued, merely because he acted in obedience to the order of the Executive Government, or of any officer of State; and it further appears ... that if the trespass had been committed by some subordinate officer of a Government Department or of the Crown, by the order of a superior official, that superior official - even if he were the head of the Government Department in which the subordinate official was employed, or whatever his official position - could be sued; but in such a case the superior official could be sued, not because of, but despite of, the fact that he was an officer of State ... [T] [Te head of a Government Department is not liable for the neglect or torts of officials in the Department, unless it can be shewn that the act complained of was substantially the act of the head himself: in which case he would be liable as an individual, just as a stranger committing the same act would be."

There is no substantial problem in establishing liability in case of torts such as trespass and conversion, but when issues of negligence arise there is a real problem, which is quite apparent from contemplation of what is involved in actions based on negligence, but which has in any event been firmly underlined by high authority. That is that before an individual Crown servant can be made liable a duty must be found which rests upon the servant personally. This appears in Adams v. Naylor [1946] A.C.543 where the nominated defendant device was used to bring the substantive issues before the Court. Boys 
playing on sand dunes entered a minefield to recover a ball and caused a mine to explode, injuring one boy and killing another. In an action based on negligence in respect of fencing the minefield and warning of danger, it was alleged that the nominated defendant was at all material times in control and responsible for the maintenance and safeguarding of the minefield. The substantive issue was whether the injuries were "war injuries" within the meaning of a statute barring claims in respect of such injuries. Referring to the nominated defendant device Viscount Simon said. (at 550):

"The courts before whom such a case as this come have to decide it as between the parties before them and have nothing to do with the fact that the Crown stands behind the defendant. For the plaintiffs to succeed, apart from the statute, they must prove that the defendant himself owed a duty of care to the plaintiffs and has failed in discharging that duty $\ldots$ it may be useful to put on record, in passing, that the success of the plaintiffs would depend on establishing the personal liability of the defendant to them, as the Crown is not in any sense a party to the action."

This view was endorsed by all the Law Lords, clearly in an endeavour to, urge the enactment of legislation subjecting the Crown to liability in tort. The monition contained in the last two sentences of the extract from Viscount Simon's speech quoted above was perhaps not fully appreciated by those responsible for the subsequent legislation. As will be shown (post p.156) the duty of care issue referred to in Adams $v$. Naylor may well prove 
to be an inhibiting factor when it is considered in relation to the statutory device adopted to make the Crown suable in tort and to the modern decisions of high authority on the nature of vicarious liability. What was obiter in Adams $v$. Naylor on this issue was clearly the ratio of the decision in Royster v. Cavey [1947] I K.B. 204 (C.A.) on essentially similar facts.

\section{Infringement of Personal Rights or Rights of}

Personal liability of the servants of the Crown was clearly established in respect of acts done in the counse of their duties which infringed personal or property rights of the subject. It would appear that Crown servants found themselves in the same situation as other servants committing torts in the course of their employment i.e. that they were personally liable for them, and were without a defence such as statutory authority to fall back on - cf. Niclintock v. The Commonwealth (1947) 75 C.I.R.I at 19 per Iatham C.J. referred to above (p.47). In addition to the situations referred to above, in respect of the general proposition it was agreed in Tinkler v. Poole (1770) 5 Burr 2657; 98 E.R.396 that an action in trover lay against a Custom-House officer for 
seizing goods not liable to duty and the report indicates that there were earlier decisions in the same vein; an award was made against a naval officer in Madrazo v. Willes (1820) 3 B. \& Ald.353; 106 E.R.629 for unlawfully detaining a Spanish slave ship and disposing of the slave cargo. Madrazo's case is remarkable for the fact that damages were awarded not only in respect of the detention of the ship but also for the value of the cargo, notwithstanding that the slave trade was by British law unlawful, the ground being that it was a lawful trade for a Spanish subject. When action for trespass in respect of a person imprisoned was translated to the local scene, it would have succeeded, (but for an Act of Indemnity) not only against a gaoler who removed a man from that part of a prison in which he was properly confined to another part, but also against the Secretary of State under whose general instructions the act was done if those instructions had been ultra vires: Cobbett v. Sir George Grey and Hudson (1849) 4 Ex 729; 154 E.R.1409. The basis of the gaoler's liability was that it would be a trespass wrongly to make a man go from one part of the prison to ahother when there existed provision specifying in what part he should be confined. The liability of the Secretary of State appears to have been considered also to be direct rather than vicarious. Pollock C.B. had reservations at least in respect of the gaoler, on the 
basis that violation by the gaoler of rules given to him by the Secretary of State with respect to the classification of prisoners would not expose him to suit at the instance of the prisoner, because he had a duty to confine the prisoner. He might be responsible to the authorities for his violation of the rules but not to the prisoner unless the latter was fettered or offered violence. A somewhat similar viewpoint as to the effect of prison regulations was accepted by the High Court of Australia in Flynn V. R. (1949) 79 C.I.R.I. and in the Australian cases in which the distinction was made between provisions regulating the duties of officers as between themselves and the State which employed them and those regulating the relationship between the state or public officer and individual citizens - cf. Zachariassen v. The Commonwealth and other decisions referred to at p.48 above. Where the claim is based upon statutory provisions this issue is one of interpretation, but a similar situation, it is suggested, may arise where the claim is based on negligence at common law - cf. discussion pp.155-166 below.

- The notion of personal liability on the part of the Crown sevant involved in a case of unlawful detention appears recently to have been accepted wjthout question see Kuchenmeister v. Home Office and Another [1958] I Q.B. 496 where damages for false imprisonment were awarded 
against the Crown and the Crown servant concerned.

\section{Military Cases:}

In military matters involving disputes between soldiers the Courts were much more loth to intervene. For instance in Dawkins v. Iord Rokeby (1866) $4 \mathrm{~F}$. \& F. 806; 176 I.R.800 it was held that no action would lie at the suit of an officer against his commanding officer for false imprisonment, malicious prosecution and conspiracy to remove the plaintiff from the Army. An arcument based on convenience commended itself to the Court:

" Now it would be a platitude for me to lay down the necessity, and the absolute necessity, of the maintenance of the constitutional liberties of the subjects of this country. Those constitutional liberties will, however, be found to be best maintained by each departinent of the Government keeping within its own proper limits, as assigned by law. It is clear that, with respect to those matters placed within the jurisdiction of the military forces, so far as soldiers are concerned, military men must determine them." (p.831).

Willes J. indicated that ordinary citizens not subject to military law might have resort to the courts for injuries to person or property done by the military and the military would have to answer there (p.831) but as between soldiers, military disputes must be settled by military procedures if discipline and good order in the Army was not to be undermined $(\mathrm{p} .841)$. A similar approach was 
taken by Mellor and Iush JJ. in Dawkins v. Iord Faulet (1869) I.R.5 Q.B.94 where the plaintiff sued his superior military officer for libel in respect of reports to a higher superior as a result of which the plaintiff was forced to leave his regiment. One of the defences put forward was that no action would lie in respect of such duties imposed on an officer of the Army, on the basis that such officers must not be in the position of having their views subjected to the scrutiny and judgment of the Courts. Nellor J. said:

"How can a commander fully communicate his real opinion to the adjutant-general as to the conduct, qualifications, or fitness for particular duties of any officer under his command, if his opinion be prejudicial to such officer, under the dread of an action for libel, or other action, which, if he were not protected, might be brought against him by any dissatisfied subordinate officer who might consider himself aggrieved? To this it may be answered, that no action would lie, as his communication would be privileged, if made bona fide and without malice. On the other hand, it must be observed that, although his communication might be privileged under such circumstances, still cases might frequently occur in which the judge on a. trial at law would have to submit to a jury the most difficult question of military discipline, such as whether orders disobeyed were proper orders for a commander to give,

- or given maliciously and not bona fide, or whether the opinion expressed as to the competence of a subordinate officer for particular duties was justifiable or not. The promotion of an incompetent man liay cause the greatest disaster, and yet, if the person who has to make his report as to the fitness or unfitness of such officer is to do it under the idea that the opinion he 
expresses may be overruled by a jury ignorant of such matters, how can he be expected to do it freely?" (p.115).

(Such an argument, as has been noted in Chapter III above, was persuasive in Barr v. Matteo (1959) 360 U.S.564). After referring to the principle that "the law will rather suffer a private mischief than a public inconvenience" and to the need for freedom from action of members of Parliament and the Courts Mellor J. continued:

"... in like manner, Ministers of the Crown cannot, from reasons of the highest policy and convenience, be called to account in an action for any advice which they think right to tender to the Sovereign however prejudicial such advice may be to individuals. Do not these reasons of public policy and convenience strongly apply to the present case? Can the administrative duties discharged by officers of the army in the position of the defendant be liable to be reviewed by a jury in an action at law without producing the greatest mischief and public inconvenience? ... [The Army] is now, and has been for many years, regulated by acts of parliament, and by articles of war framed under them which provide appropriate courts and suitable machinery, and there is now a secretary of state for war, expressly appointed by the Crown, with a series of officers charged with particular duties and functions, all tending to the regulation and government of Her Majesty's forces and I cannot but think that the analogies referred to do in principle apply to such a state of things. Upon these considerations ... I came to the conclusion that the present action will not lie."

Both Mellor and Iush JJ. were clearly moved to this view by the fact that the Army Act and Articles of 
War provided an avenue for redress of wrongs other than the ordinary Courts but the judgment of Iush J. does not dissent from the views of Mellor J. as to the necessity for the rule. Cockburn C.J. dissented from the extension of freedom from suit to all military matters and would have limited the freedom to the exercise of powers not maliciously i.e. with honesty of purpose, opening to the jurisdiction of the Courts intentional abuse of powers for the purposes of injury or wrong (p.102). This accorded with the view of the Court of Exchequer in Sutton v. Johnstone (1786) I T.R.493; 99 E.R.1215 (reversed on the facts I T.R.510; 99 E.R.1225, the reversal being affirmed by the House of Lords: I T.R.784; 99 E.R.1377):

"... the [universal] principle [is]'that where it can be shown that one man has causelessly and maliciously accused another of a crime, or has otherwise vexed him by causelessly and maliciously exercising upon him, to his damage, powers incident to his situation of superior, the injured party is entitled to redress by this species of action.' The commander in chief of a squadron of ships of war is in the condition of every other subject of this country, who being put in authority, has responsibility annexed to his situation." ( 1 T.R. at 503).

- Cockburn C.J. in Dawkins V. Iord Paulet (supra) again following Sutton's case indicated that it was always the function of the courts to punish abuse of powers. He very vigorously dissented from the view as to the necessity, from public convenience or the competence of 
the Court, for freeing all disputes between military officers from the Court's jurisdiction (pp.107-9).

Cockburn C.J's view that the freedom from suit described in respect of military matters does not extend to protect a soldier who oversteps military requirements entirely has some more recent support in Iindsay v. Iovell [1917] V.I.R. 734, a somewhat extraordinary case of assault by military policemen on a soldier.

6. Official Communications of State:

An argument from convenience, similar to that advanced in the military cases, appears in the rule relating to absolute privilege in libel actions sought to be based on official communications of state and has perhaps percolated into the law relating to privilege from production of State documents - see Corbett v. Social Security Commission [1962] N.Z.L.R.878 (C.A.). This is clearly to be found in Chatterton $v$. Secretary of State for India [1895] 2 Q.B.189 (C.A.). The action was to be based on, a statement made by the Secretary of State for India to the Parliamentary Under-Secretary for Indis in order to enable him to answer a question in the House of Commons with regard to the treatment of the plaintiff, an officer in the Indian Staff Corps, by the Indian military 
authorities and Government. Iord Esher M.R., supported by Kay and A.I.Smith I.JJ. said (p.191):

"... it is not competent to a civil court to entertain a suit in respect of the action of an official of state in making such a communication to another official in the course of his official duty, or to enquire whether or not he acted maliciously in making it ... The reason for the law ... is that it would be injurious to the public interest that such an enquiry should be allowed, because it would tend to take from an officer of state his freedom of action in a matter concerning the public weal. If an officer of state were liable to an action of libel in respect of such a communication as this, actual malice could be alleged to rebut a plea of privilege, and it would be necessary that he should be called as a witness to deny that he acted maliciously. That he should be placed in such a position, and that his conduct should be so questioned before a jury, would clearly be against the public interest, and prejudicial to the independence necessary for the performance of his functions as an official of state. Therefore the law confers upon him an absolute privilege in such a case."

This protection has been extended to communications from a High Commissioner to his Prime Minister (Isaacs \& Sons Ltd. v. Cook [1925] 2 K.B.391, and from a Minister to his subordinate even in respect of commercial matters, so long as the commication is in respect of official business: Peerless Bakery v. Watts [1955] N.Z.I.R.339. A wider privilege in the same field of tort has been extended in the United States: Barr v. Matteo (1959) 360 Us564 noted in detail in Chapter III, but the dissents in that case present a strong argument against 
too great an extension of absolute immunity. It may be however that the views of the minority in Barr v. Natteo are more apt to actions against officers below Cabinet rank than to actions against Ninisters, since there would appear to be a substantial social interest in not requiring Winisters to answer for their acts to a Court.

\section{Failure to perform Statutory duty:}

So much for direct infringenent of personal or property rights which fit easily into the framework of nominate torts. In addition to these cases, clear principles have been developed imposing liability on public servants who fail to carry out duties imposed on them by statute, to the detriment of individual citizens.

These cases are concerned with what have been described as "purely ministerial" duties in respect of which there will be liability on proof of default and injury, and a special interest vested in the plaintiff. Thus in Schinotti v. Bumsted (1796) 6 T.R.646; 101 E.R. 750 it was determined that commissioners of a lottery to raise $\$ 500,000$ for the Crown, acting pursuant to the statute 33 Geo.3 c.62, were merely ministerial officers and could be sued for failure to carry out their duties. The Commissioners were directed by Act of Parliament to 
do certain acts "all of them ministerial not judicial acts ... [I]f the defendants be only ministerial officers, they are liable to an action." (p.649/50). In this case no question of malice or want of care was in issue; the action proceeded purely on failure to perform a duty, as a result of which the plaintiff had been deprived of a prize. At trial he was awarded against the Commissioners the value of his lost prize.

An action in respect of breach of ministerial duties was allowed without any allegation of malice in Barry v. Arnaud (1839) 10 Ad. \& E.646; 113 E.R.245, where indeed the failure to perform the duty was brought about by an error of law. The action was for loss on a cargo of tobacco in respect of which a collector of customs had refused to sign a bill of entry on tender of the amount of duty. There was a dispute over the proper amount of duty which turned on the proper classification of the goods and the Court had to determine this as well as whether the collector was liable in an action. On the issue whether if the proper amount of duty had been tendered an action could be maintained against the Collector for refusing to sign the entry the Court's opinion was clear. Iord Denman C.J. for a Court of four Judges said:

"[The first point was] whether, assuming that the plaintiff had tendered the proper amount of duty, any action could be maintained against the defendant for refusing to accept 
it and sign a bill of entry, whereby the plaintiff was prevented from obtaining the delivery of the tobacco in question and selling it to advantage. And we are of opinion that such action is maintainable, although no malice or ill-motive is imputed to the defendant. ... The nature of [his] duties is next to be considered; and, as regards the present question, they are plainly and merely ministerial. He is, according to the statement, to collect the proper amount of duty, and sign the bill of entry. This is not the less a ministerial duty because, in some instances, as in the present, it may not be clear upon the face of the statute what the proper amount of duty may be. Difficulties both of law and fact arise repeatedly to ministerial functionaries, such as the sheriff, in the discharge of his duties; but these do not alter their nature. The defendant then is a public ministerial officer, and, being so, he is responsible for neglect of his duty to any individual who sustains damage by such neglect." (pp:669-671).

The Court held that the Collector's view as to the proper classification was wrong and that an action lay. It appears an unhappy situation that the collector should have to form a view on the law properly applicable on penalty of an action should he be wrong, but such results can, and should, be eliminated by proper statutory drafting - cf. comments of the judges of Kings Bench in Warne V. Varle.y (1795) 6 T.R.443; 101 E.R.639. By way of defence a finding was sought that the collector was merely carrying out, as a servant, a duty imposed on the Commissioners, but the view which formed the basis of the Australian decisions of Enever and Baume destroyed this 
Customs, was in this instance not merely the agent or servant of the Commissioners of Customs, but was himself a substantive and immediate officer of the Crown, charged with the execution of a certain limited duty and personally responsible for it:

"It is true that, in the performance of that duty, he is subject to the control of the commissioners; but it is still his own duty, not theirs, that he is to perform; the acts which he does are his own acts, not theirs; their control is not an arbitrary one, but limited by the provisions of the statute wherever. they apply, and does not absolve him from responsibility to persons affected by the due performance. or neglect of his duties." (p.670).

If further authority be needed in respect of ministerial duties, one need go no further than Ferguson v. Kinnoull (1842) 9 Cl. \& Fin.251; 8 E.R.412, an action against a Scottish Presbytery for refusing to take a minister on trial when they were bound by the statute 10 Anne c.12 to do so and notwithstanding a judgment of the House of Iords that they were bound to do so (Auchterarder v. Kinnoull (1839) 6 Cl. \& Fin.646; 7 E.R.841). The House was agreed that an action lay. The Lord Chancellor laid down the principle very shortly:

"here was a public duty, which the parties were bound to perform; they knew that the $y$ were bound to perform it. They neglected that duty. Individuals have sustained injury in consequence of their neglect of that duty. It was not a judicial act; it was an act that was imperative upon them, and with respect to which they could exercise no discretion. These are the parties that did the act, and they are the parties, therefore, against whom 
the action is maintainable". (p.283).

Iord Brougham agreed with this proposition as did Iord Campbell, referring to the duty of the Presbytery to take the Ninister on trial as a "purely ministerial" act $(\mathrm{pp} \cdot \dot{3} 12,3)$. Lord Brougham adverted shortly to the issue of malice:

"In the present case that is alleged and proved which is tantamount to malice; illegal conduct in violation of duty, and injurious to the party; and the conduct is alleged to be continued refusal to do an act declared by a judgment to be imperative .... In Drew v. Coulton and indeed in Ashby v. White such averment seems to have been held sufficient allegation of malice. If the acts alleged to be illegal and in violation of duty, had been alleged in terms to have been wilfully done, there can be no doubt that this would have come up to an averment of malice. But the word 'wilful' need not be used any more than the word 'malice'. The continued illegal refusal is clearly equivalent to wilfully doing an illegal act." (pp.303-4).

A clear and important distinction was drawn in this case between the failure to perform a ministerial duty to make a decision and matters arising out of the decision itself. The latter are to be separately judged if they later come in issue, with perhaps a different result. Thus, per Iord Campbell at p.312:

"When the members of the Presbytery were required to take $\mathbb{N} r$ Young on trial, in my opinion they were required to do a mere ministerial act. Touching that act they had no discretion; they had no judgment to exercise. How then could it be judicial? There is no difficulty whatsoever in separating the act of appointing him to 
appear before them to be examined, and the act of forming a judgment on his qualifications when he has appeared before them and been examined. It is for refusal to do the first act that this action is brought, and the first act is purely ministerial."

8. Action based on the exercise of statutory powers:

In contrast to the firm and unqualified liability imposed in respect of nonfeasance and misfeasance in relation to ministerial duties, the Counts have adopted a different approach to the exercise of powers involving the making of a determination or the exercise of an administrative discretion.

In cases where a determination has to be made by the person exercising the power, there is a line of cases extending at least from 1703 when in Ashby v. White 6 Nod. 46; 87 I.R.810 the Court of King's Bench by a majority of three to one denied a right of recovery, in an action against an officer conducting a poll, for maliciously refusing to record a vote. The majority denied a right of action because the decision was that of the polling officer who had a quasi-judicial function; the remedy for error lay in Parliament; so far as the plaintiff was concerned it was a case of damnum sine injuria in that he suffered no loss; and because if one action lay, many would, which would be a matter of great inconvenience, the principle 
here being one which might be compared to some degree with that which operates in respect of public nuisance or in the field of administrative law where the locus standi of the plaintiff. may give rise to difficulty - cf. S.A. de Smith, Judicial Review of Administrative Action (1959) p.305; Collins v. Iower Hutt City Corporation [1961] N.Z.I.M.250. The majority in Ashby v. White were not united in their reasons, one at least (Powell J.) being of the view that an action might lie after Parliament had determined on an election petition that the plaintiff had been denied his richt. Holt C.J., dissenting, denied that there was any judicial element in the polling officer's decision. His duty was merely to carry out the poll and as such was ministerial. Furthermore the Chief Justice recognised the existence of a right without any determination by Parliament and accepted that it was a right sufficient to maintain an action for abuse of it. He was not perturbed by the lack of evidence of financial harm - for the infringement of the right damages could be recovered. The argument from the inconvenience of a multiplicity of actions was distinguished - for one wrong affecting many there might not be an action but for many individual wrongs there could be, and indeed should be:

"the encouraging of remedies for injuries is the most effectual way to make these officers honest and observant of the constitutions of their cities and boroughs; and they would 
decline such practices as we daily see them guilty of." (p.55).

As for the jurisdiction of Parliament to determine election matters, Holt C.J. thought this of little use to the plaintiff since his preferred candidates had been elected - he had nothing to object to Parliament about.

On a writ of error to the House of Lords, the judgment in Kings Bench was reversed and judgment was given for the plaintiff: (1703) I Bro.P.C.62; I E.R.417. According to some reports the decision is authority for the proposition that an action lay not for erroneously excluding a vote, but only for fraudulently and maliciously doing so - see Smith's Leading Cases 13 Ed. (1929) Vol.1 p.283, Drewe v. Coulton (1787) I East 563; 102 E.R.217 and Tozer v. Child (1857) $7 \mathrm{El}$. \& B1.377; 119 I.R.1286. It is apparent from the report of Tozer's case that the issue whether the returning officer's duty was wholly ministerial or partly judicial in character was not then considered to be concluded (ibid p.382) although in Smith's Leading Cases (ibid pp.283/4) authority is given for the proposition that it was purely ministerial.

In Brasyer v. McIean (1875) I.R.6 P.C.398 it was held that a public officer was liable in tort for misfeasance without proof of malice or want of probable cause. Although the action was against a sheriff, it seems likely 
that it had a statutory basis, since that office in a colony existed by force of a statutory enactment - Sir John Holker a.C., Solicitor-General (arguendo), I.R.6 P.C. at $\mathrm{p} .402$. Nuclean was the sheriff of New South Wales who had an absconding defendant arrested under a writ of capias ad respondendum, the arrested man being thereafter rescued from custody. In his return on the writ McLean indicated that Brasyer was one of the rescuers. An order of attachment for contempt was made against Brasyer and he was imprisoned; the sheriff's return that he had been one of the rescuers being conclusive in the comptempt proceedings. In the action for damages for a false return of rescue on a writ of arrest it was contended that the sheriff had not acted maliciously and was therefore not liable, being protected because he was executing a process of law. The Privy Council held otherwise:

"This is a case of misfeasance by a public ministerial officer in the discharge of his duties. The sheriff was intrusted with the power of making a return to the Court which would be considered conclusive by the court as to the truth of the facts stated in the return. He was enabled, therefore, by virtue of his office, to make a return to the Court in this particular instance, which was conclusive in that stage of the proceedings, that the plaintiff did rescue Wylie from his custody, and he therefore had the power, and he exercised the power of doin that which rendered the plaintiff liable to an attachment for a contempt of - Court ... .

It appears, therefore, ... that the 
sheriff in this case was guilty of a misfeasance in the exercise of the powers which were intrusted to him by law and in the discharge of his duty as a public ministerial officer, and that in respect of that misfeasance he is liable to an action for the damage which resulted from that act, notwithstanding that it was not proved against him that he was actuated by malicious motives. The mere fact of the misfeasance and the damage resulting from it by reason of the attachment issuing upon the return as conclusive evidence against the plaintiff was sufficient damage to enable the plaintiff to maintain an action against the sheriff for that misfeasance ...". (pp.405-6).

There is no suggestion in the Privy Council decision that the action was one for false imprisonment and since the plaintiff was imprisoned on a judicial order such an action would not lie - cf. Salmond on Torts 14 Ed. p.181. The defendant had sought to avoid liability on the basis that the injury to the plaintiff was caused by the order of the court and that he was not liable in respect of his information which led to the making of that order without proof of malice and want of probsble cause; cf. the requirements in malicious prosecution and malicious arrest - salmond,op.cit. pp.586/7. The Privy Council distinguished that class of case on the ground that the sheriff's return was conclusive as to its truth and the Court which imprisoned the plaintiff reached its decision (in accortance with established practice) without allowing him to show cause against the truth of the return. The decision of the Privy Council refers to the 
defendant's act in terms of the exercise of a "power" but from the context it appears that the case may have been one of a statutory power which carried with it as a corollary an implied duty to exercise it correctly. If this is the proper view the case is similar to that of Barry v. Arnaud (supra p.120).

The exercise of a power which formed the basis of the decision in Fartridge v. General Medical Council (1890) 25 q.B.D.90 was spoken of as "discretionary" but it is clear that what was in issue was the making of a determination on an issue - a matter having a quasijudicial flavour (cf. S.A.de Smith, Judicial Review of Administrative Action (1959) p.202n, where it is susgested that the decision was open to attack on one of the bases used to attack quasi-judicial decisions). Partridge sued the Council for unlawfully and maliciously causing his name to be removed from the register of dentists. It was found at trial that the defendants had acted without malice and in an endeavour to do their dut: under the Dentists Act 1878. Two sections of the Act were in issue: Soll which related to the keeping of the register and required the resistrar to act on the directions of the Council and s.13 which empowered the Council to have names removed from the register for infamous conduct etc. The Council, without hearing the plaintiff, required his name 
to be removed when his qualification was withdrawn by another body. In the court of hppeal it was held that the Counci. was performing the duties imposed by the Act. Had the functions been those under s.13 they would have been julicial and the Council not liable in an action if they acted without malice, even if erroneously (per Iord Esher M.R. at 95). If the functions were those under s.ll they were discretionary and not merely ministerial, and the members of the Council were similarly not liable. Iord Esher equated the discretionary decision with the judicial:

"I think [the direction to remove] is clearly discretionary. Now it appears to me that it is a true proposition to say that, when a public duty is imposed by ict of Parliament upon a body of persons, which duty consists in the exercise of a discretion, it cannot be said that the exercise of that discretion is a merely ministerial act. If what the defendants did cannot be cpnsidered to have been merely ministerial, then I think for the purposes of the question, whether they are protected from an action, it must be considered as judicial. It appears to me that a body such as the defendants can only be made subject to an action for things which they have done erroneously without malice in carrying out their duties under the ict, if it can be shown that they were - acting merely ministerially".

Fry and Iopes I.JJ. concurred in this view. In respect of the making of executive or administrative decisions not having any judicial or quasijudicial flavour, old authorities similarly provided very 
limited relief against the public officer. In Bassett v. Godschall (1770) 3 Wilks. K.B.121; 95 E.R.967 relating to the exercise of a discretion (the point of the decision perhaps being a little blurred by reason of the fact that it related to justices of the peace, although it apparently refers to administrative functions of justices) an endeavour was made to sue justices for wrongly and maliciously refusing an inn-keeper's licence to a qualified person. The judements indicate that in this respect justices exercised a discretionary power (as indeed it appears from the statute 26 Geo.2 c.31 they might in respect of the number of licences issued, in addition to power of determination in respect of the suitability of applicants) and would be answerable on indictment for wilful and knowing abuse of power, or for misbehaviour in the execution of their office (including by wrongfully granting a licence) - see R. V. Holland (1787) I Term R.693; 99 E.R.1324; but that they would not be liable to an action by a dissatisfied applicant, for until a licence was granted the applicant had no right in respect of it.

Two decisions subsequent to Bassett's case relating to discretionary powers referred to the motive of the public officer in exercising his power, with 
conflicting results. The first was Dickson V. Combermere, Peel and Others (1863) 3 F. \& F.527 (N.P.); 176 E.R.236. The action against General Peel, who was secretary of State for War, was for wrongfully causing the removal of the plaintiff, a military officer, from the Army on false charges. Cockburn C.J. indicated that as to whether the Secretary of State had exercised his discretion wisely or mistakenly, it was a matter for which he was answerable to the Crown and not in a suit by the injured party. He could only be sued if he dishonestly and corruptly abused his powers $(p p \cdot 583 / 4)$.

In the second decision it was held that even if the body exercising a statutory discretion is actuated by improper motives in reaching its decision no action will lie agrainst the members of the body: Davis v. Bromley Corporation [1907] I K.B.170 (C.A.). There it was allesed that a local borough council acting as a sanitary authority had rejected plans for a house because of previous litigation between the builder who submitted the plans and the council. The Court's judgment said:

- "Even assuming the facts to be such as to sujgest that the defendants were actuated by such motives, there remains the fact that the Legislature has vested in this body the duty of deciding whether or not its sanction shall be given to the plans sent in. In my opinion, where a statute vests in a local authority such a duty and such a power, no action will lie against that authority in respect of its decision, even if there is some evidence to show 
that the individual members of the authority were actuated by bitterness or some other indirect motive. The intention of the Iegislature was that there should not be an opportunity of setting aside or getting rid of the decision of a local authority by bringing an action against that authority: and it is obvious that a jury would not be a convenient tribunal for the trial of such an action" (pp.172/3).

Both Bassett's case and Davis's case must now be considered in the light of Everett v. Griffiths [1921] 1 A.C. 631 and David v. Cader [1963] I A.I.R.834 (P.C.). Everett's case related to a decision involving personal liberty. Griffiths was the Chairman of a Board of Guardians of whom it was alleged that he, acting without good faith and reasonable care, caused the plaintiff to be confined as insane. The charge of bad faith was not persisted in. The Chairman made the detention order pursuant to a provision in the Iunacy Act which authorised a justice to make such an order if, after certain prescribed preliminaries, he was "satisfied" that the lunatic should be detained. The powers of a justice had been extended to the Chairman by statute. The Iaw Iords all considered whether the Chaiman had a judicial iffunity from suit or whether he had an immunity based on other considerations. All, except Iord Atkinsor, who proceeded on the basis of a judicial immunity, based their judgments on a broad proposition as to the liabilities of those exercising stetutory powers. Viscount Haldane at 
first posed the issue broadly, viz. whether the Chairman was entitled to the same immunity as a judge of a court of record or whether, if he was acting only in an administrative capacity, he was liable for failure to exercise reasonable care $(p .659)$, and regarded it as one of considerable difficulty:

"The tendency of modern legislation has recently been to entrust to many who are prima facie only administrative officers, functions which - have some judicigl attributes at all events, although they remain primarily administrators. What protection do they enjoy? The point of law today is not as simple as it was, comparatively speaking, some years ago. The recent decisions of this House in Board of Education v. Rice [1911] A.C.179 and in Local Government Board V. Arlidge [1915] A.C.120 indicate that in the case of administrative awards there are at least some enforceable obligations which those making them must observe [to act in good faith, hear both sides etc.]. [The question] what these are and to what extent they go ... may prove in particular cases a delicate and obscure one. Some rimitation of the application in such instances of the broad principle of complete judicial immunity may well prove to be involved in its resolution."

The resolution of this difficulty was not attempted and Iord Haldane was content to rest his judgment on a general proposition relating to those exercising statutory power:

"Provided that the person entrusted by Parliament with the statutory duty of satisfying himself in the fashion prescribed by the Act ... and then to act, in fulfilment of the statutory duty ... keeps within his jurisdiction, observing the prescribed conditions, and acting bona fide and honestly, I think that he'is only doing what Parliament has called on him to do, and has thereby made lawful .... . If he does his best to act fairly within the limits laid down for him, he has acted up to the standard prescribed and I do 
not think he can be made liable to an action at common law for want of care beyond this. For assuming that he has actually satisfied himself, acting honestly and bona fide in arriving at his conclusion and proceeding on it, he has done the very thing which the statute told him to do, and no further question arises." (p.660).

Viscount Finlay similarly put the matter on this general basis in respect of those discharging public duties in preference to the basis of complete judicial immunity. Ater referring to Partridge v. General Medical Council (supra) Viscount Finlay said:

"The section ... of course, imports that he must be honestly satisfied, but if the justice of the peace or chaiman is so honestly satisfied he cannot be made liable on the ground that he hos been negligent in arriving at his conclusion. So to hold would in fact be to make him liable to be harassed in the honest execution of his statutory duties by actions in which a jury would be invited to say that he was ne ligent in arriving at his conclusion. (p.665) ... Negligence, even if established, would not create any liability so long as he acted honestly." (p.667).

Viscount Cave similarly disregarded the judicial immunity issue (p.679), and proceeded on the same general basis, extending the immunity not only to the conclusion drawn by the chairman, but also to the judgment as to what preliminary enquiries should be made as a basis for that conclusion (p.678). Iord Nioulton also eschewed the "judicial" issue and proceeded on the "universal rule applicable in all cases" (p.696) that:

"if a man is required in the discharge of a 
public duty to make a decision which affects, by its legal consequences, the liberty or property of others, and he performs that duty and makes that decision honestly and in good faith, it is, in my opinion, a fundamental principle of our law that he is protected. It is not consonant with the principles of our law to require a man to make such a decision in the discharge of his duty to the public and then to leave him in peril by reason of the consequences to others of that decision, provided that he has acted honestly in making that decision ... The law may of course affix conditions as to the exercise of any such public duty ... [and] it is clear that the ... public officer exercising the jurisdiction must comply with the conditions if he is to bring himself within the protection ... [If he does so] he is entitled to protection in respect of that decision and its legal consequences, whether that decision was right or wrong in fact, because it was honestly arrived at in the discharge of his duty."

Lord Atkinson proceeded on the basis that the act of the chairman was a judicial act and as such imported immunity if performed honestly (p.687).

$$
\text { David V. Cader [1963] I W.I.R.834 (F.C.) refers }
$$

to the question whether an applicant for a licence has any basis for a cause of action before he has been granted the licence, but also dealswith the general issue of the basis of the official's liability. It was alleged that a licence to operate a cinema had been maliciously refused in spite of compliance with all the statutory requirements. The Supreme Court of Ceylon on appeal affirmed the trial judge's dismissal of the action on the ground that until the licence was granted the applicant had no legal right. 
and unless an antecedent legal right had been infringed

there was no right to damages. The Privy Council said:

"The question to be determined is not what rights he had without a licence, but rather what rights were created between these two parties by the relationship under which one wished to operate a cinema and had applied for a licence to do so and the ot er had the statutory responsibility for deciding how to deal with that application. Whatever the limits of the range of the latter's discretion in carrying out that responsibility, a separate question which would need careful consideration if the action came to be tried, the appellant has at any rate pleaded that he had doneeverything required to qualify him for the grant of a licence and that he was . entitled to have one issued. Given that relationship and the assumption of that state of facts, it seems to their Lordships impossible to say that the respondent did not owe some duty to the appellant with regard to the execution of his statutory power; and if, as pleaded, he had been malicious in refusing or neglecting to grant the licence, it is equally impossible to say without investigation of the facts that there cannot have been a breach of duty giving rise to a claim for darnages." (p.839).

In respect of Davis's case the Board said:

"Davis's case was decided in the year 1907. Since then the English counts have had to give much consideration to the general question of the rights of the individual dependent on the exercise of statutory powers by a public authority, and the decision of that case would now have to be seen in the context of a very great number of later decisions that have dealt with the question at more length and with more elaboration. In their Iordships' opinion it would not be correct today to treat it as establishing any wide general principle in this field: certainly it would not be correct to treat it as sufficient to found the proposition, as asserted here, that an applicant for a statutory licence can in no circumstances have a right to damages if there 
has been a malicious misuse of the statutory power to grant the licence. Much must turn in such cases on what may prove to be the facts of the alleged misuse and in what the malice is found to consist. The presence of spite or ill-will may be insufficient in itself to render actionable a decision which has been based on unexceptionable grounds of consideration and has not been vitiated by the badness of the motive. But a "malicious" misuse of authority ... may cover a set of circumstences which go beyond the mere presence of ill-will, and in their Iordships' view it is only after the facts of malice relied on by the plaintiff have been properly ascertained that it is possible to say in a case of this sort whether or not there has been any actionable breach of duty". (pp.839/,
40).

This proposition does not necessarily carry the matter much further, for, as the writer of a comment on David's case has pointed out (1964 Camb I.J. p.4), the Board's comments are consistent with the view that improper exercise of a discretion may be in fact refusal to exercise a discretion at all and therefore breach of a statutory requirement to do so - cf. Ferguson v. Kinnoull; or the statute may in fact convert the "discretion" into a statutory duty once all the requirements of the statute are fulfilled - e.g. Barry v. Arnaud and cf. Yukich v. Sinclair [1961] N.Z.I.R.752. The latter would be distinguishable from the situation where there remains an element of policy in the decision - as perhaps in Bassett v. Godschall and cf. Broome v. Hutt Valley Consumers Coopp. Itd. [1964] N.Z.I.R.207. 
9. Acting in excess of jurisdiction:

It is convenient in conjunction with the consideration of the position of officers exercising statutory powers to refer briefly to the situation of the officer who exceeds his statutory jurisdiction or assumes powers which he does not have. It seems likely that he will be liable for all consequential damage. This appears from Acland v. Buller (1848) I Exch.837; 154 E.R.357, an action against Tithe Commissioners for wrongly issuing a certificate under the Tithe Commutation Act 6 \& 7 W.4 c.71, as a result of which the plaintiff's goods were distrained for the benefit of the owner of the land who was entitled to tithes. The statutory pre-requisite before the Commissioners had jurisdiction was a dispute in respect of the tithes and it was alleged that to the knowledge of the Commissioners no such dispute had arisen. There was dispute during the argument whether the Commissioners' function was judicial but the Court's decision on the demurrer does not resolve this. It was held that an action would lie.

In most such cases of excess of jurisdiction the action will be founded on one of the specific and recognised actions in tort - see per Evershed M.R. -and Denning I.J. in Abbott v. Sullivan [1952] I K.B.189 at 192 and 201-2, the statute arising by way of defence. It is 
not clear from the reports but it would appear to be on this basis that the action against the rural district council Clerk was allowed to proceed in Smith v. East Elloe Rural District Council and Others [1956] A.C.736 i.e. on the basis of fraud see e.g. per Viscount Simonds at p.752, although this may be doubtful - see per R. Winn arguendo p.748. The action did not proceed to trial A. .J. Bradley in [1964] Camb.I.J.4 at p.7. In these cases an analogy may be drawn with the position of the judges of inferior courts, who are liable in trespass for acts done to the plaintiff or his property as a result of their wrongful assumption of jurisdiction under a mistake of law - Polly v. Fordham [1904] 2 K.B.345; O'Connor v. Isaacs [1956] 2 Q.B.288. The cause of action against the judges of inferior courts does not rest on the making of the invalid order and malice is not relevant. If the plaintiff himself acts to his detriment in respect of an invalid order made or direction given in good faith, apparently no action will lie - cf. McClintock v. The Commonwealth (1947) 75 C.I.R.I at 19 per Latham C.J. and o'Connor v. Isaacs (supra), but cf. Farrington v. Thomson [1959] V.R.286 at 296/297 where this proposition was doubted except perhaps in respect of judicial orders. So far as the comments in Farrington's case relate to' orders made bona fide, they are obiter since there was a finding that the order given in that case was given in the 
knowledge that there was no power to give it.

Where a decision in excess of jurisdiction is made in bad faith there will clearly be liability for consequential acts of others affecting the person or property of the plaintiff. Where such a decision leads to the plaintiff acting to his own detriment there may be no remedy unless the plaintiff can base his action in fraud or unless there is a separate action for abuse of office, which is dealt with in the next section.

10. Abuse of office:

In some of the cases there has been talk of an action against a public officer for "abuse of office" or "misfeasance in public office". Thus in Henly v. Nayor of Iyme (1828) 5 Bing 91; 130 E.R.995, Best C.J. very briskly laid down that a public officer was liable/:

"I take it to be perfectly clear, that if a public officer abuses his office, either by an act of omission or commission, and the consequences of that is an injury to an individual, an action may be maintained against such public officer. The instances of this are so numerous, that it would

- be a waste of time to refer to them. Then, what constitutes a public officer? In my opinion, everyone who is appointed to discharge a public duty, and receives a compensation in whatever shape, whether from the Crown or otherwise, is constituted a public officer." (p.107).

It is not quite so clear however what the basis of liability is. After the proposition cited above, the 
Chief Justice referred to a series of cases where liability would exist: the Bishop who in consequence of the grant of estates, has a duty to hold ecclesiastical courts, will be liable at the suit of a man who suffered financial loss because he was unable to obtain probate of a will in consequence of the Bishop's failure to set up the court; the clergyman who refuses to administer the sacrament to a man who is thereby prejudiced in his civil rights, will be liable at that man's suit; the clergyman who neglects to register a person brought to be baptised, in consequence of which the latter loses an estate, will be liable in a suit; the Bank of England will be liable for refusal to transfer stock; the lord of a manor will be liable for failing to hold a court which he is bound to do, if someone thereby suffers loss. Best C.J. went on:

"It seems to me that all these cases establish the principle, that if a man takes a reward, whatever be the nature of that reward, whether it be in money from the Crown, whether it be in land from the Crown, whether it be in lands or money from any individual, - for the discharge of a public duty, that instant he becomes a public officer; and if by any act of negligence or any act of abuse in his office, any individual sustains an injury, that - individual is entitled to redress in a civil action ... . But it has been argued, that this only applies to acts, and not to mere omission. That argument cannot be sustained: because in the case which has been referred to from Cowper [Nayor of Iynn v. Turner (1774)

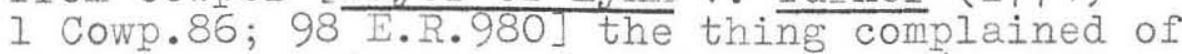
was a mere omission or negligence." (pp.107109). 
The first proposition taken alone has been accepted to be authority for the proposition that there is a right of action for "abuse of office" or "misfeasance in public office" - see e.g. Farrington v. Thomson and Bridgeland [1959] V.R.286 at 293 in which case a successful claim for damages was brought against a police officer by a hotel licensee who closed his hotel for the supply of liquor in conformity with an order given by the defendant, which order, it was found, the defendant knew he had no authority to give. It was clearly considered unnecessary to establish malice in the sense of an intent to injure, but that it was necessary to establish that the public officer's act was to his knowledge an abuse of his office i.e.done without just caues and excuse. This decision seems to be an extension of the principle laid down in the class of cases Best C.J. referred to which were really actions for failure to perform ministerial duties. Henly's case was an action by an individual who suffered loss in consequence of the decay of seawalls, which the Corporation was directed to repair under the terms of a grant from the Crown conveying a borough to the Corporation. Turner's case was of a similar nature but the duty there was based on immemorial usage. It is true that the term "negligence" was used by Best c.J. in Henly's case but 
in its context it appears to mean no more than nonfeasance (an acceptable (S.O.D.(1933) Vol.2) but now not very common meaning of the word). It may well be that most of the "abuse of office" cases fall within one of the two previous catecories.

Another instance which might be classified as abuse of office falling into neither of these categories is that of Roncarelli v. Duplessis (1959) 16 D.I.R. (2d) 689 in which damages were awarded at the suit of a restaurant proprietor against the Premier and Attorney-General of quebec who directed or instigated the cancellation of the plaintiff's liquor licence by the Quebec Iiquor Commission to punish him for bis activities in acting as bondsman for persons charged with seditious activities. The defendant was held liable for unwarrantably intruding on the functions of a statutory body in respect of which he had no statutory or official powers.

There appear to be none but these cases to illustrate this area, which shoula accordingly be - regarded as one developed so far only in hazy outline.

11. Difficulties arising in actions based on'the exercise of Statutory vowers:

(i) Statutory interpretation: In every action 
relating to activities in respect of which there is a relevant statutory provision there may be problems of interpretation - whether the statute imposes a duty or merely confers a power, whether a statute imposin; a duty is in terms absolute or leaves available defences based on good faith or reasonableness, and whether a statute which in terms imposes a duty is mandatory or directory only. These matters are dealt with in the standard texts on statutory interpretetion and it is not proposed to deal further with them here - cf. Craies on Statute Law 6 Ed. (1963) Ch.12 pp.258 et seq. and Maxwell on the Interpretation of Statutes 11 Ed. (1962) pp.231-241, 349-372.

(ii) What right of the plaintiff is detrimentally

In cases relating to the exercise of statutory powers the difficulty arises of distinguishing what right of the plaintiff has been affected, the invasion of which gives a remedy in tort. This debate has continued at least from Ashby v. White (1703) 6 Mod. 45; 87 E.R.810, continues through Bassett's case and Davis's case and appears little nearer to solution in terms of a general proposition in David v. Cader [1963] I W.I.R.834 (P.C.). A general basis of liability was formulated thus in Rogers $v$. Rajendro Dutt (1860) 13 Noo.P.C.C.209 at pp.216-8, 15 E.R.78: 
"Gerhard v. Bates (2 Ell. and Bla., 476), is a clear authority for the position that if the wrong and the consequential loss are, to use Iord Campbell's phrase (ib.490), 'clearly concatenated as cause and effect', the action is maintainable, although it does not arise from any public wrong, or the neglect of any public duty, and the parties are entire strangers to each other, no privity subsisting between them. Have we, then, here alleged a tort, occasioning a loss to the plaintiffs? The loss is clearly stated, but it may be damnum sine injuria; or, if the tort be established, the loss may not be sufficiently 'concatenated with it as cause and effect'; or, in other words, may be too remote to be the subject of an action. Now, if we turn to the definition of a tort in Broom's Comms. so often cited at the bar, we find that, if not founded on the violation of some special duty, public or private, it may be founded simply on the invasion of a legal right; and the fallacy in some of the arguments used for the Defendant consisted in the erroneous statement, or in the absence of a clear perception, of the right which the plaintiffs say the Defendant has invaded ... . The invasion, to be actionable, must, of course, be wrongful ... [I]n every complicated society, the exercise, however legitimate, by each member of his particular rights; or the discharge, however legitimate, by each member, of his particular duties; can hardly fail occasionally to cause conflicts of interest which will be detrimental to some".

This does not, however, assist in resolving the problem when what is detrimentally affected is not the plaintiff's person, reputation, property or existing economic interest, but a "right" which is a concomitant of personal status such as the "right" to vote, or a potential economic benefit such as may be derived from the obtaining 
of a licence. Iittle help is gained from distinctions such as Salmond's distinction between proprietary and personal rights (Jurisprudence 7 Ed. (1924) pp.264 et seq.; 11 Ed. (1957) p.289 et seq.) because some of the "rights" which he classified as personal are protected by the law of tort e.g. personal liberty, reputation and freedom from bodily harm: ibid. p.265. This problem is not confined to issues arising from the activities of public authorities", for it is reflected in discussions of actions for invasion of privacy or infringement of a status - Salmond on Torts $14 \mathrm{Ed}$. (1965) pp.21 and 24 and in actions against private licensing authorities - Nagle v. Feilden [1966] 2 W.I.R. 1027 (C.A.) and cases therein referred to, and has been attractively related to negligence - E.A.Nachin:

"ivegligence and Interest" (1954) 17 M.I.R.405. The judgment of liaxwell J. in Revesz $\mathrm{V}$. The Commonwealth (1950) 51 S.R. (N.S.W.) 63 provides an example of the determination of whether a cause of action existed by reference to the "right" of the plaintiff which was harmed. The action was against a licensing authority for negligence, and in Maxwell J.'s judgment the claim was said to have failed because no property or right of property was affected such as would support the claim.

No assistance in establishing criteria seems to be obtained from distinctions which are found useful in the field of administrative law e.g. by basing the conditions 
of tort liability on whether a function is "judicial" or "quasi-judicial" on the one hand or "executive" or "administrative" on the other. It might, for example, be desirable in appropriate cases to rovide a remedy in tort for the activities of a licensing officer exercising the powers discussed in Vodern Theatres Itd. v. Peryman [1960] N.Z.I.R.191, but most undesirable and impracticable to provide such a remedy in respect of the type of powers considered in Buller Hospital Board v. Attomey-General [1959] N.Z.I. R.1259. Since the powers in both cases were considered to be administrative with no judicial overtones no help is to be derived from this distinction.

In Salmond on Torts 14 ad. pp.23-24 it is suggested that this field is open for development:

"There are cases which indicate that damage caused by the excessive or malicious or negligent exercise of statutory powers by a public authority is actionable. This is an area of the law which may see some developments. In the present age it is of great importance that statutory powers of licensing and control should be exercised honestly and fairly. The public law remedies of the prerogative orders for quashing erroneous decisions may need to be reinforced by an action for damages."

The line of development might be to adopt a principle of construction that the bestowal of powers by statute carries a correlative duty to exercise the powers reasonably and honestly cf. Everett v. Griffiths (supra), or to develop the liability for "abuse of office" which 
is referred to in Farrington's case (supra) and Roncarelli's case, requiring for liability some of the factors to be found in the action for malicious prosecution: e. . unreasonableness in the sense of lack of due judgment, care and discretion, and malice in the sense of acting from some improper motive. In either case the "right" which would provide the basis of the claim would be something of the nature of a "right to be treated fairly". Such a development might however have very undesirable effects on administrative processes and may well require the balancing of societal interests in the determination of whether claims so based should be allowed in tort. Development along the lines indicated would centainly still involve the determination of the basis on which damages are to be assessed, and, if they are to be compensatory rather than punitive, of what should be the proper measure of damages. This is an area of difficulty, but not one of insuperable difficulty. The Courts are well fitted by their experience to assess damages for losses flowing from harms done to individuals. Indeed, it is probable that, after criminal proceedings, the largest number of cases determined by the ordinary Courts require the assessment of damages for tangible losses and intangible detriments, be they past, present or future, whether they are precisely assessable by mathematical calculation or not, and whether or not 
provision should be made for contingencies wich might have eventuated had the defendant's act or omission not intervened in the counse of events.

(iii) Whether the court can properly determine all Where an action against a public authority is based on one of the recognised nominate torts and the statute is raised by way of defence, the principles to be applied appear from the decisions of the Courts in private actions based on those torts. It seems clear, however, that the problems in respect of tort claims based purely on the exercise of discretionary powers are by no means fully worked out, and that to base such claims on the "right" referred to above would not resolve them. Error, even negligent error (which would perhaps extend to cover defects which, in its administrative law jurisdiction, the Court would remedy - cf. Associated Picture Houses Itd. v. Wednesbury Corporation [1948] I K.B.223), does not provide a basis for an action (Everett's case, Partridse's case and Dickson's case), nor does wrongful motive alone (David's case and cf. Allen v. Flood [1898] A.C.I.). The Privy Council in David's case referred to the possibility of a decision made on unexceptionable grounds being "vitiated by the badness of the motive" but as has been suggested this is much the same as a breach of a statutory duty to decide. Even if the right of action is confined to situations where 
an erroneous decision has been made and the official has been actuated by an improper motive the problem remains (which plainly led the Court in Davis's case to its decision) whether the court can in many cases properly make a determination that the original decision was erroneous. It is, it is suggested, one thing for the Court to say that a discretionary decision was reached by improper procedures or on improper considerations, or is wholly or in part ultra vires, but quite another to say what the decision would or should be if proper procedures were followed or only proper considerations were taken into account. Professor de smith in Judicial Review of Administrative Action (1959) p.405 has suguested that the law as to the remedy of declaration, where a similar problem arises, is by no means yet clear and he recognises (ibid pp.411/2) that it may be inappropriate for the court to make a "correct" determination in place of that impugned. The problem is more acute in the area of tort than it is in the supervisory jurisdiction of the Courts in the field of administrative law. In that field the Courts can fulfil their function by striking down the impugned decision and leaving the matter to the tribunal to decide again in accordance with law - cf. for example, Ski Enterprises Itd. V. Tongariro National Park Board '[1964] N.Z.I.R.884. No such easy way out is available when the Court's determination as to the correctness of the 
decision is the first step in an action for damages, because, it is suggested, the correct decision must also be determined before the Court can conclude that there has been a detriment to the plaintiff giving rise to a right to be paid damages. Even if the consideration of damages be confined to exemplary damages (cf. Hayne \& McGregor on Damages 12 Ed. (1961) pp.196 et seq. and Rookes v. Barnard [1964] A.C.1129, $1221-1233$ per Iord Devlin), the plaintiff must show that he has in fact been detrimentaly affected by the conduct which gives rise to the award e.g. per Ior Devlin in Rookes v. Barnard (supra) at p.1227. He cannot do this if a proper decision might still have been adverse to him.

For the present, the prime difficulties inherent in actions directly based on the exercise of statutory powers are merely described. Their bearing on what right of action should be available against the Crown and its servants is discussed in Chapter VI. 
CHAPTER V.

Vicarious Iiability in Crown Proceedings.

To give full consideration to how effectively rights of action against public officers personally create a governmental law of tort, it is necessary to refer briefly to the connecting link between such rights of action and the public purse. In the New Zealand, United" Kingdom and Victorian Crown Proceedings Acts the

- connecting link is vicarious liability for the acts or omissions of Crown servants or officers. Two of the problems arising in respect of what might be called. "administrative torts" have been referred to in Chapter I, i.e. liability for the torts of servants of public corporations $(\mathrm{p} .26)$ and liability in respect of the acts or omissions of persons carrying out public functions who are not otherwise employees of the Crown e. members of administrative tribunals (p.28). There is no real difficulty in respect of the torts of servants of public corporations, for the corporations can from their own funds or by insurance meet any award of dam ges and carry out any socially desirable loss-spreading.

There does however appear to be real difficulty in respect of persons specially engaged to perform administrative functions. There is no doubt that the performance of such functions is part of the general 
governmental administrative structure of the country and may therefore be said to be carried out on behalf of the Government, but the very reason for the appointment to perform such functions of persons not employed by the Crown would appear to negative the factor on wich vicarious liability of an employer or principal is based i.e. control and direction of the employee. Salmond on. Torts $14 \mathrm{Ed}$. (1965) p.648 defines a servant for the purpose of vicarious liability as

"any person employed by another to do work for him on the terms that he, the servant, is to be subject to the control and directions of his employer in respect of the manner in which his work is to be done."

The whole oint of introducing persons not ordinarily employed by the Crown into the administrative structure is to have decisions which may affect the property rights or economic activities of private persons made by persons who are independent of the Crown and subject to no control by the Crown apart from the ultimate control of revocation of appointment. The closest private analogue may be that of liability of a hospital authority for the negligence of consulting physicians and surgeons - cf. Hillyer v. St. Bartholomew's Hospital [1909] 2 K.B.820 (C.A.).

The draftsmen of the lesislation in the countries referred to above short-circuited one of the problem areas in relation to vicarious liability by referring to 
liability for the "torts" of servants"or agents, reinforcing the implications of this wording by providing (in New Zealand by the proviso tos.6(1)) that the Crown should not be liable unless the servant would be. It has been sugge ted that this proviso was inserted to preserve the Crown from liability when the servant could plead by way of defence to an action against him, "act of state" - see Street "The Crown Proceedings Act" (1948 11 M.I.R.129). This suggestion has been trenchantly criticised, on the basis that if this defence is open, there is no tort at a.11 - Street: Governmental Iiability (1953) p.38; Glanville Williams: Crown Eroceedings (1948) p.44. It has also been suggested that the intention wes to prevent the Grown from being liable in situations where the servant would be imune from suit: Glanville williams op. cit. pp.43-45. The case taken as an example of this situation is Bnith v. MOSS [1940] I K.B.424 when applied to the employer/employee situation, as happened in Broom v. Morgan [1953] I G.B.957. In Smith v. Loss it was held that an injured wife could recover damcies from the owner of a motor vehicle in which she was a passenger in respect of the negligence of the driver who was driving as agent for the owner, although she could not recover from the negligent driver, he being her husband. In Broom v. Morgan it was held by the Court of Appeal that the plaintiff wife could recover in this fact situation when 
the relationship between the husband-driver and the owner of the vehicle was that of master and servant rather than that of principal and agent. The actual tortfeasor's immunity in the husband/wife situation largely ceased to exist in New Zealand with the enactment of $\mathrm{s} .4$ of the Matrimonial Property Act 1963, but Glanville Williams (op. cit., p.45) suggests that there is no reason in point of policy why the Crown should be im une in any such situation when a private employer would not be, and this sugsestion seems sound.

The proviso, however, added emphasis to what was effected by the use of the word "torts" in s.6(1)(a) and foreshadowed developments in the general law relating to vicarious liability. There has been difference of opinion both in decisions of authority and in articles by leamed writers, on the issue whether a master is liable for the acts or omissions of his servants causing harm, irrespective of whether the servant himself has committed an actionable tort. The dispute turns on whether the master is liable because his servant's failure amounts to breach of duty on the part of the master or whether he is made liable for a breach of duty on the part of the servant. In Darling Island Stevedoring Co. Ltd. V. Iong (1956-57) 97 C.I.R.36 most of the judges preferred to base vicarious liability on a separate liability of the master unrelated to whether the servant would be liable, a view 
which commended itself to commentators before and after the decision - see e.g. Glanville Williams: "Vicarious Iiability" 72 I.Q.R.522 and J.G. Fleming in a case-note on Iong's case in 20 M.I.R.655. The view does not appear however to have commended itself to the House of Iords; Stavely Iron \& Chemical Co. Ita. v. Jones [1956] A.C.627, 639, 643 and I.C.I. V. Shatwell [1965] A.C.656, 676, 681, $685 / 6,691,693 / 4$ where the view clearly appears that unless a tort was committed by the servant for which the servant would be liable, the employer would not be vicariously liable.

The particular importance of this issue in relation to tort liability of the Crown lies in respect of actions for negligence. As a tort, it is a commonplace that negligence embraces "the complex concept of duty, breach, and damage thereby suffered by the person to whom the duty was owing" - per Iord Wright in Iochgelly Iron and Coal Co. V. MMullan [1934] A.C.I, 25, and that "the ideas of duty and negligence are strictlycorrelative and there is no such thing as negligence in the abstract; negligence is simply nejlect of some care which we are bound by law to exercise towards somebody" - per Bowen I.J. in Thomas V. Quartermaine (1887) 18 Q.B.D.685, 694; Salmond on Torts 14 Ea. (1965) p.268, Fleming: Law of Torts $3 \mathrm{Ed}$. (1965) p.110. In Crown proceedings the 
critical issue is not that which so often appeans in this field, whether a duty was owed to the plaintiff but whether in a given case a duty was owed to the plaintiff by any Crown servant, as distinct from the Crown as an entity.

The point is made very clearly in the judgments of the Supreme Court of Victoria in Hall V. Whatmore [1961] V.R.225. The claim was one made against the Inspector-General of Penal Establishments in respect of injuries suffered by a prison inmate, under s.23(I)(b) of the Crown Proceedings Act 1958 (Vict.). This, which is the sole provision of that ict in respect of actions in tort, provides:

"(I) Subject to this part...

(b) the Crown shall be liable for the torts of any servant or agent of the Crown ... as nearly as possible in the same manner as a subject is liable for the torts of his servant or agent ...".

As to this Herring C.J. and Dean J. said at p.225:

"We think it is clear from s.23.... that before the Crown can be held liable under the section it must appear that some servant or servants of the Crown is or are liable in tort. Where, as here, the relevant tort is negligence, t is means that there has been a breach by a servant or servants of the Crown of a duty owed by that servant or by those servants to the plaintiff."

and Hudson J. at pp.228/9:

"The Solicitor-General on behalf of the defendants contended that this provision has not the effect of imposing on the Crown the 
same duties as those which would be imposed on a subject in like circumstances and liability for breach thereof. What it does, he contended, is to impose on the Crown a liability that is truly vicarious and arises upon the breach by a servant ... in the course of his employment, of a duty imposed upon that servant ... so that the servant is himself liable in tort... . In my opinion the Solicitor-General's contention is clearly correct and the liability that is imposed on the Crown under $\mathbf{s} .23$ cannot originate in a duty resting upon the Crown.

In order to succeed in his claim against the State of Victoria therefore the plaintiff must establish a breach in the course of his employment by one of the servants of the Crown of a duty owed by that servant to the plaintiff. It will not avail the plaintiff to establish some act or omission on the part of the Crown which in the case of a subject would constitute a breach by the latter of some duty resting upon him arising out of the ownership or occupation of premises or chattels alleged to be dangerous."

The last sentence of the citation from Hudson J. does not apply to the New Zealand situation because of the provisions of $\mathrm{s} .6(1)(\mathrm{c})$ of the Crown Froceedings Act 1950 (N.Z.), but the reasoning applies to any situation in respect of which direct liability against the Crown is not provided for by the New Zealind Act.

No great problem would appear to arise where, as in the case of the nominate torts, the servant's act alleged to be negligent directly affects the plaintiff, even if through the acts or omissions of a third party brought about by the servant's negligence. Such cases would include the negligence of auditors (New Plymouth 
Borough v. The King [1951] N.Z.I. R.49); perhaps of inspectors certifying as to safety (cf. Goodman v. New Plymouth Fire Board [1958] N.Z.I.R.767 and W.I.Morison: "Liability in Negligence for False Statements" (1951) 67 I. R.212 at 225); of persons giving advice as to a state of fact (cf. Hedley Byrne \& Co. Ita. v. Heller \& Eartners Itd. [1964] A.C.465 and Bames v. Comnonvealth (1937) 37 S.R. (N.S:K.) 511), or as to a course of action to be taken (cf. Woods v. Martin's Bank Ltd. [1959] I Q.B. 55 and article by $\mathbf{W}$.I. Morison referred to above: 67 I. .R.at 226); and of persons giving instructions (cf. Clayton v. Woodman and Son Itd. [1962] 2 Q.B.533), particularly if the instructions are required by law to be obeyed.

The problem area is where there has been a defect in or total failure of an enterprise, brought about by an employee's careless performance of his duty to the Crown, the damage to the third party being brought about by that defect in or failure of the enterprise. The question whether (apart from statutorý duty) there can be an action for loss caused by delay (e.g. in issuing a licence) is one example of this type of issue. The distinction between duty to the employer not giving rise to a cause of action, and duty to third parties which will do so has already been presaged (supra p.48). The 
difficulty in this situation arises from the basic proposition that there is ordinarily no liability unless a duty is cast on the defendant in favour of the plaintiff: and it seems that the area of difficulty is that of omissions to act. The general principle is expressed by Salmond on Torts $14 \mathrm{Ed}$. (1965) pp.291/2 thus:

"In the absence of some existing duty the general principle is that there is no liability for a mere omission to act. The fundamental notion appears to be that the imposition of an obligation to take positive steps for the benefit of another requires that that other should furnish something by way of consideration. So there is no legal obligation to warn one who is about to walk into a trap or rescue him from his perilous situation when he has done so. Thus one servant owes to another no duty to warn that other against a danger which no action of his has caused or contributed to: a mere nonfeasance without more, even though it may be a breach of duty to the master, is not a wrong to the fellow servant .... . It is clear that one who has already entered into some relationship with another may be liable to that other for omissions as well as for acts."

The decisions which impose liability on those who undertake public services such as the provision of marine warning lights or have such services entrusted to them by statute, in either case whether for private profit or not, accord with this proposition. By embarking on the enterprise they undertake the liabilities arising from it. Thus in Mersey Docks Trustees V. Gibbs (1866) I.R.I H.I.93 there is discussion of the "neglect" or "negligence" of the Trustees' servants, but it is clear 
that, what was in issue was the Trustees' liability for the failure to perform their own duty, which of necessity had to be performed through their servants:

"So lon: as the dock was kept open for the public, the duty to take reasonable care that the dock and its entrance were in such a state that those who navigate it may do so without danger, was equily cast on the persons having the receipt of the tolls and the possession and manazement of the dock, whether the tolls were received for a beneficial or a fiduciary purpose.

If this proposition is correct, the airection ... was richt, for a body corporate can never take care or neglect to take care, except through its servants; and (assuming that it was the duty of these trustees to take reasonable care that the dock was in a fit state), it seems cleax that if they, by their servants, had the means of knowing thet the dock was in $n$ unfit state, and were negligently ignorant of its state, they did neelect tris duty, and did not take care that it was fit ... [ [W]e are of the opinion that the judgment was correct". per BIackburn J. at p.104, delivering the joint opinion of five judges which was approved by the House of Lords - (1866) I.R.I H.I. at 123 and 126.

A similar obligation to nemove or mark wrecks was held in Dormont $v$. Fumess R1.. Co. (1883) 11 j.B.D.496 to be laid on a harbour authority because of the receipt by them of dues which were to be applię in maintaining, buoying and lighting the channel; on the Trinity House Cor oration for failure propecly to remove a wrecked beacon, the management and control of lighthouses and beacons being vested in the corporation: Gilbert $v$. Corporation of Mrinity House (1896) 17. B.D.795; and on

a Corporation which constructed and operated an airport, 
but failed to remove a danger from the landing approach:

Hesketh v. Iiverpool Corporation [1940] 4 g11 I.R.429. Day J. in Gilbert's case shortly stated the law at pp.799/ 800:

"The law is plain that whosoever undertakes the performance of, or is bound to perform, duties - whether they are duties imposed by reason of the possession of property, or by the assumption of an office, or however they may arise - is liable for injuries caused by his ne ligent discharge of those duties. It matters not whether he makes money or a profit by means of discher ing the duties, or whether it be a corporation or an inaividual who has undertaken to discharge them. It is also immaterial whether the person is guilty of negligence by himself or by his scrvants. If he elects to perform the duties by his servants, if in the nature of things he is obliged to perform duties by employing servants, he is responsible for their acts in the same way that he is responsible for his own."

Very clearly, however, what he is responsible for is failure to perform his own duty.

Is there, however, any corresponding duty on the part of the servant who has not vis-a-vis the plaintiff embarked on any undertaking? It is clear that he cannot escape personal liability for his acts merely because he is acting as a servant:

"There remains to be considered the responsibilities incurred by servants either to strangers or one to another. Those obligations which the law imposes on all persons independently of contract can manifestly not be affected by the constitution of relations to which the injured person is not a consenting party; and as the servant is liable for any injury he may do to the person or property 
of another by force of his position as a member of the community and subject to its laws; so his own act in putting himself in relations of subordination to another will not excuse him from answering for the consequences of acts or omissions he would otherwise have been bound to." Beven on Negligence $4 \mathrm{Ed}$. (1928) Vol.1 p.848;

but this points the issue whether he is personally liable to third parties for omissions.

This distinction between omissions and acts of commission on the part of the servant in respect of a matter incumbent on the master has the benediction of Holt C.J. in Lane V. Cotton 12 Mod.473; 88 E.R.1458 and in respect of acts of commission the situation is more plain since Donoghue v. Stevenson [1932] A.C.562, for there will be little difficulty in finding a relationship from which will arise a duty of care on the part of the servant once the servant has done a positive act. Iane v. Cotton was an action against a postmaster for loss of a package entrusted to an inferior officer. In the course of his judgment Holt C.J. said:

"It was objected at the bar, that they have this remedy against Breese [the inferior officer]. I agree, if they could prove that he took out the bills, they might sue him for it; so they might anybody else on whom they could fix that

- fact; but for a neglect in him they can have no remedy against him; for they must consider him only as a servant; and then his neglect is only chargeable on his master, or principal; for a servant or deputy, quatenus such, cannot be charged for neglect, but the principal only shall be charged for it; but for a misfeasance an action will lie against a servant or deputy, but not quatenus a deputy or servant, but as a wrongdoer." (p.488). 
and this distinction was affimed by the court of Kings Bench in Ferkins v. Hughes (1752) Say 40,41; 96 I.R.796. The principle that a breach of duty to the employer in respect of a matter in which the employer owes a duty may not give rise to a cause of action against the employee by a third partyhas been applied in employment cases cf. Judson $v$. British Transport Commission [1954] I All I.R. 624 and in respect of injuries to prisoners alleged to be due to an omission by a prison officer: Quinn v. Hill [1957] V.R.439. The principle would appear to apply only in the case of true omissions and not in cases where an omission appears only on considering the facts from a particular aspect cf. Harnett v. Bond [1924]2 K.B.517,54]; Hawkins V. Coulsdon U.D.C. [1954] 1 Q.B.319; Quinn v. Hill (supra); Horgan V. Attorney-General [1965] N.Z.I.R. 134,142. To hold that the servant was liable in the case of true omissions one would have not only to establish that there existed duty relationships between master and third party and between servant and master but also to take the further step of saying that the several relationships of the servant and the third party with the employer gave rise to a relationship between third party and the servant. Such authority as there is and the general principles of legal relationships seem to be asainst the correctness of such a proposition. The views expressed above accord with the decisions of the Supreme court of 
Canada in The King v. Anthony [1946] 3 D.I.R.577 and Grossman and Sun v. The King [1952] 2 D.I.R.241.

Iiability of the Crown in Canada depends on $s .19(1)(c)$ of the Exchequer, Court Act 1927 which allows "every claim against the Crown arising out of any death or injury to the person or to property resulting from the negligence of any officer or servant of the Crown while acting within the scope of his duties or employment". In Anthony's case it was accepted that the Act created liability against the Crown under the rule of respondeat superior but did not impose duties on the Crown in favour of subjects. The liability was held to be vicarious, conditioned on the servant of the Crown having drawn upon himself a personal liability to the injured person. It did not rest merely on the negligent failure of a servant of the crown to carry out a duty to the Crown; there must be breach of a duty to the injured person; otherwise there would be imposed on the Crown a greater responsibility in relation to a servant than rests on a private citizen: [1946] 3 D'.I.R. at 585. The distinction was drawn in Grossman's case between a non-feasance which involved a mere breach of duty to the master and a non-feasance where there existed in the circumstances a duty on the part of the employee in favoup of third persons or an apparent non-feasance which was in reality a misfeasance. In either of the last two situations it was held there would be a liability on the 
part of the servant for which the Crown would be vicariously liable.

If the views expressed above are correct, to return to the example of the lighthouse, the position will be that in respect of a negligent misfeasance of a servant, e. - joining up wires incorrectly, the Crown will be liable because the servant would be liable under the Donoghue v. Stevenson principle once he embarked on the matter. If however the servant goes to the beach for the day and does nothing, even though he is in breach of his duty to his employer the Crown will not be liable, because the servant, being under no duty, is not liable for pure nonfeasance. This result will not be affected by the fact that the Crown would be liable if it could be directly sued. These principles must apply in all similar situations.

It may be that this situation will arise rarely as a result of the definition of the word "servant" by the Crown Proceedings Amendment Act 1958 to include Ministers of the Crow , since the usual statutory formula setting up Government Departments in New Zealand provides that the appropniate Minister is to have the general administration of the Act, a provision which would doubtless be interpreted sufficiently widely by the courts to place on the Minister legal as well as political responsibility for everything done in pursuance of the Act - see e.g. s.3 
Civil Aviation Act 1964, s.4 Education Act 1964, s.7 Shipping and Seamen Act 1952; but there may be no such provision e. 8 . in the Mining Act 1926 , the Coal Mines Act 1925, the Forests Act 1949 or the Government Railways Lct 1949. However, even where the Iinister is not charged specifically with over-all responsibility for the administration of the Act he is normally given statutory powers to undertake works which would sufficiently link him with the undertaking to make him a legitimate subject of allegations relating to failure of the enterprise, e.g. Part III of the Coal Mines Act 1925, s.10 et seq. of the Government Railways Act 1949, s.15 Forests Act 1949 (see a.lso e.g. s.14 of the Forests Act 1949 and $s .4$ of the Civil Aviation Act 1964 which give the administration of the Act to the Department but "under the control" or "under the direction" of the Minister).

A further possible problem arising from the device used to make the Crown answerable in tort results from the condition of vicarious liability that the servant's acts or omissions giving rise to liability must have been done or omitted whilst he was acting in the course of his employment: Salmond on Torts 14 Ed. (1965) p.648. The wrong will be deemed so to have been done if it is authorised by the master or is an unauthorised mode of doing some act authorised by the master - Salmond op. 
cit. p.685. The question whether the servant had actual or implied authority is one of fact: United Africa Co.Itd. -v. Owade [1957] 3 All E.R.216 P.C. but if the servant has ostensibly actual or implied authority to do what he has done the master will not be allowed to set up by way of defence that he in fact had no such authority Iloyd v. Grace, Smith \& Co. [1912] A.C.716. The usual distinction is between acts or omissions coming within those categories and acts or omissions which are so separated from what the servant is employed to do as to be his ow independent acts or omissions. It was by application of one aspect of this principle that the employer was not liable in Enever v. The King (1906) 3 C.I.R.969 and in respect of some of the allegations in Baume $v$. The Commonwealth (1906) 4 C.I.R.97 or in Stanbuny v. Exeter Corporstion [1905] 2 K.B.838. By reference to this distinction the Courts have determined the employer's liability when the servant has caused injury or loss after he has arrogated the duties of others to himself: Beard v. Iondon General Omnibus Co. [1900] 2 Q.B.530; caused a customer wrongly to be arrested for passing counterfeit coin: Abrahams V. Deakin [1891] I Q.B.516; caused to be injured a boy whom he thought to be stealing his employer's property; Poland v. Parr \& Sons [1927] I K.B. 236; acted in defiance of express instructions as to the manner of doing his work: C.P.R. V. Iockhart [1942] 
A.C.591; made fraudulent representations: Barwick v. English Joint Stock Bank (1867) I.R.2 Exch.259, even though the fraud may be for the benefit of the servant only: Lloyd v. Grace, Smith \& Co. [1912] 1.0.716; and when the servant's wrong has been motivated by vengeance, malice or resentment unless the circumstances are such as to make the matter a purely personal affair: Warren $v$. Henleys Itd. [1948] 2 Al1 I.R.935.

In the face of such problems met and overcome, the issue which it is thought may arise in respect of Crown servants is that of ultra vires actions giving rise to claims in tort. The mere fact that an act is ultra vires does not give rise to a cause of action in damages: per Dixon J. in James $v$. The Commonwealth (1938-39) 62 C.I.R. 339 and Iatham .J. in McClintock $v$. The Commonwealth (1947) 75 C.I.R.I, and Dixon J. warned against allowing this issue to give rise to a defence in favour of the Crown:

"It is important to see that, once there is found a de facto authority from the crown in right of the Comonwealth within the scope of which an alleged tort is committed, the

- doctrine of ultra vires is not used to produce the same immunity as formerly arose from the incompetence of an officer at common law to bind the Crown by his tortious acts". - James V. The Commonwealth (supra) at 0.360 . 
act, since the ultra vires issue of its nature goes to positive acts only. Nor does it appear that the ultra vires issue raised in respect of acts done by the servants of corporations beyond the powers of the corporation can arise in respect of the Crown e.s. as in Foulton v. Iondon \& S.W.Railway (1867) I.R.2 Q.B.534 or in Campbell v. Paddington Corporation [1911] I K.B.869. In every case likely to arise in respect of Crown servants which is not covered by the ostensible authority decisions such as Iloyd v. Grace, Smith \& Co. (supra) the problem will be simply overcome if the Court defines the scope of the servant's employment sufficiently widely for the ultra vires act to be a mode of doing what the servant was employed to do rather than an act too remote to be part of the employment. Such a decision would be in accordance with authority. Thus in Barwick v. English Joint Stock Bank (1867) I.R.2 Exch.259 referred to with approval in Iloyd v. Grace, Smith \& Co. Willes J. said:

"In all these cases it may be said, as it was said here, that the master has not authorised the act. It is true that he has not authorised the particular act, but he has put the agent in his place to do that class of

- acts, and he must be answerable for the manner in which that agent has conducted himself in doing the business which it was the act of his master to place him in."

Thus if a timber inspector, authorised to have destroyed timber infested with wood-boring beetles has timber destroyed which is not so infested, there is no problem so 
long as the scope of his duties is defined as "timber inspection and associated matters."

Thus, it is suggested there are four situations

in which a plaintiff may not recover damages from the Crown in New Zealand in respect of injury suffered at the hands of Crown servants, because of the limitations of the device of vicarious liability used in the Crown Proceedings Act 1950:

(a) where his dumage is caused by a person not ordinarily a servant of the Crown who is retained to perform a particular administrative function;

(b) where the servant's conduct is such as to be tortious, but he is for some reason personal to himself immune from suit;

(c) where the servant has no sufficient relationship with the plaintiff to give rise to a duty of care, notwithstanding that the relationship between the Crown and the plaintiff is such that a direct duty of care by a private emoloyer for the plaintiff would exist in the same circumstances;

(d) where damage results from an ultra vires act of a Crown servant.

Because of the attitude which it is suggested 
above is likely to be taken by the courts in claims involving the fourth of these situations, there is probably little need to regand this as a problem requiring a remedy. The second and third situations, however, present difficulties which do not appear reconcilable with a legislative intention senerally to make the Crown liable in situations in which a private person would be liable in tort. As a manifestation of this intention the provisions of $\mathrm{s} .6(\mathrm{I})(\mathrm{b})$ and (c) of the New Zealand Crown Proceedings cet 1950 are particularly significant, in that they make the Crown directly liable in respect of breach of an employer's duties to his servants and in respect of breach of the duties attaching to the ownership, occupation, possession or control of property. It would be consistent with these provisions to provide for what one might call an "enterprise liability" available against the Crown directly in respect of enterprises which have a private analogue or which at least have no particular governmental character. In making provision for such liability, however, considerable care would be required in drafting to ensure that tort liability did not unintentionally extend into areas of governmental activity from wich for good reason it should be excluded. The situation referred to in (b) above would be remedied by the repeal of the proviso to $s .6(1)$ of the Act. 
to above, also appears to require statutory provision for its solution. It also, however, requires first a deternination of the extent to which a tort remedy should be allowed in relation to govemmental administrative activity. If it is desirable to extend the Crown's tontious liability to the acts and omissions of persons exercising administrative functions, care will be needed in defining precisely the activity in respect of which there is to be liability and in desining the authorities in respect of the activities of which the Crown will accept the burden of liability. Some administrative functions are performed wholly or in part by authorities which are, in their ordinary jurisdictions, local or resional authorities (e.8. the functions of municipal corporations under the Town \& Country Planning Act 1953 and under the Dangerous Goods Act 1957) and it might be more suitable to leave the liabilities to tilose, authorities notwithstanding that they are in a particulor matter carrying out part of a national planning scheme. Possible revisions of the legislation are discussed in the next Chapter. 
CHAPTER VI.

Conclusions and suggestions for reform:

The object of subjecting the Crown to liability in tort might be broadly expressed as: to make provision whereby the State will compensate individual citizens for those harms caused to them by government officers or state activity, which in the public interest should be compensated. The public interest in this definition includes the equitable distribution of the burdens of living in organised society.

Much State action requires, in the interests of the whole community, the regulation of the activities of individuals or the subordination of the interests of a minority. Two issues arise from these requirements of community life and it is suggested that neither issue is a legal one, viz. whether the individual is to have any loss caused to him spread over the whole community or i's to bear it himself and, if the loss is to be spread, whether this is to be effected by way of general or particular legislation providing for compensation or by allowing a tort remedy in the ordinary Courts. (A noteworthy demonstration of the fact that these are alternative ways of dealing with the same problem is presented by the course of events of which the action Dalehite v. United States (1953) 346 U.S.I5 (p.71 et seq. above) was one. After the 
actions failed, compensation was provided by legislation, the Texas City Disaster Relief Act (1955): Jaffe: Judicial Control of Administrative Action (1965) p.258).

In respect of some detriments caused to individual citizens by state action, it is usual to have legislative provision requiring the State to pay compensation, e.g. under the Public Works Act, 1928, but such provisions for compensation are usually applied only to the construction and operation of public works. In respect of some other detriments it can be decided without difficulty that the loss should be spread over the community by being compensated by the State, and that the ordinary Courts acting through the medium of tort actions are the appropriate tribunals to decide the issues arising, but in other cases these decisions are less easy and less certainly "right".

Some of the suggestions referred to in the Introduction ( $\mathrm{p} . \mathrm{x}$ et $\mathrm{seq}$. ) as to methods to be used in subjecting the State to its proper liability to individuals are founded on the view that most, if not all, detriments to individuals should be compensated by the community. I have suggested (Introduction xii, xiii) that even to provide that the State should compensate every individual who suffers exceptional loss exceeding that of his lellow citizens is unsatisfactory because of the likely total cost to the comunity, and because of the practical difficulty 
in defining 'exceptional loss', particularly when the loss is related to the curtailment or elimination of the possibility of future opportunities. As a matter of practicability, some narrower approach seems to be necessary

As soon as it is accepted that anything but the widest approach last referred to is the proper one, it must be determined which agency, the Legislature or the Courts or other tribunal appointed to adjucate individual cases, is to define the boundaries of the area within which claims may be made. The descriptions of the New Zealand, Australian and United States law in Chapters I, II and III illustrate the use of each of these agencies for determining this policy issue. They illustrate also that neither course is without pitfalls. It is seen to be difficult for the Legislature clearly to define the situations in which it wishes the state to provide compensation and to separate these from the situations for which it does not wish such provision to be made, or to provide a yardstick by which the claim can be evaluated in the situations where there is to be a remedy. It is equally difficult for the Courts if this matter is left to them: a policy decision is a legislative function and involves considerations with which the Courts are neither accustomed to nor organised for dealing. The suggested methods of subjecting the State to liability referred to 
in the Introduction ( $\mathrm{p} \cdot \mathrm{x})$ relate to this issue.

On the basis that this primary issue is a political and not a legal one and that it should be performed by a political and not a legal organ of the State, my own view is that the Legislature should determine it and should specify with some particularity the limits of the State's liability to individuals.

The basic criterion of any approach but the wide one of compensation for loss or exceptional loss discussed above, must be either error or fault. If error is made the basis, the Courts of necessity become the ultimate arbiters of administrative decision, a function which is not ordinarily (and for good reason) regarded as that of the judiciary. This leaves only fault. It must be accepted that fault as a criterion will be as open to criticism where the State is the defendant as it may be, in any analagous situation involving private citizens - cf. e.g. Report of the Committee on Absolute Liability: Government Printer (1963) and that there is special dirficulty in tort actions related to much official ostivity: that of finding an objective standard by which to judge the propriety of such activity. In such cases where the latter difficulty arises, the universal compensation solution having been discarded, it may be that it will not be practicable to provide a remedy through the medium of the ordinary Courts. 
The most convenient way of determining what detriments by the State should be compensated through the courts is to consider the type of activity or function involved and the difficulties or drawbacks (if any) arising from subjection of each type to the jurisdiction of the courts.

The first category of activity is that performed every day by citizens for their own purposes or in their capacities as employees of private employers, e.g. driving motor vehicles, operating machines or performing any activity which, if harm results to another, is typically the subject of a negligence action. It may be accepted that the State should be liable for all such harm on exactly the same basis a.s any private employer would be in respect of his employees. For complete conformity with this view, the proviso to s.6(I) of the Crown Proceedings Act 1950 would have to be repealed ( $p .153-155$ above). There appears to be no good reason for the state not to accept liability in, respect of borrowed servants on the same basis as a private person would have to ( $p .26$ above) and provision should be made for liability in respect of the activities of independent contractors to the same extent as a private person would be liable.

The second category of activity is that which has been referred to in Chapter V (p.159 et seq. above) as giving rise to 'enterprise liability'. Within this 
category are included those enterprises embarked upon by the government which are analagous to the enterprises conducted by commercial organisations (as opposed to functions such as the conduct of war and the operation of prisons, which have no private counterpart) and services provided by the government which are made use of and relied upon by private persons in the conduct of their own affairs and which may have no private counterpart in New Zealand (although there may be a private counterpart in other countries), but which could, all things being equal, be provided as well by private enterprise as by the state. In respect of the commercial enterprise activities, e.g. coal mining, timber production, electricity production and public transport operated directly by the state, it is suggested that the Crown's tort liability should exactly parallel that of analagous private enterprise. In respect of services provided by the Government e.g. navigational aids and warning devices provided for shipping and aviation, traffic signals and warnings, and motorvehicle testing stations, the Crown should be under a direct liability comparable with that which would be imposed on a nongovernmental body which undertook to supply the same service. In the case of services there should be no possibility of a finding of liability based on the quality or quantity of the service provided or the time when it is provided, insofar as these are determined as a matter of 
governmental choice. This would accord with the United States approach expressed in the discretionary/operational distinction and it is suggested that this approach is a proper one.

Care in legislative drafting would be required in respect of this second category of activity to ensure that only services which it is appropriate should be treated on the same basis as a similar private enterprise, would be so treated. It might indeed be necessary to specify the services which were to be the subject of the direct liability suggested, if there is no analagous private activity in New Zealand, for a New Zealand Court would find it difficult to determine a New Zealand problem of this type by reference to what is done in other countries e.g. by comparison with the Trinity House Corporation in the United Kingdom. The situation which was the subject of the decision in Indian Towing Co. v. United States (1955) 350 U.S.61 (p.80 above) illustrates the difficulty. There will doubtless be differences of opinion on the services which should be the subject of this type of liability, but such a service as the inspection of timber for the detection of harmful insects, which is performed primarily for the public benefit rather than for private reliance, should not, it is suggested, be made the subject of direct tort liability. Some government activities, e.g. the 
meteorological service, fall partly into one and partly into the other class, and appropriate provision would have to be made for such cases. Consideration of the synopsis of cases in 99 A.I.R.2d 1011 et seq. referred to at page 91 above suggests other services which could fall to be dealt with under this second category of activity.

Regulatory activity provides a third category. Typically, regulation is done in a legislative form and there are apparently no cases in which the Courts have recognised a tort liability based on unreasonable or erroneous content of such legislation, even if it is of delegated or sub-delegated origin, or on impropriety or incorrect or unreasonable decisions in the course of the process of which the regulation is the end product. There seems to be no question that such activity should not be made the subject of tort actions. However, the form of regulatory activity which directly affects individuals rather than the community as a whole, and relates to particular instances rather than to general circumstances, e.g. the functions of an air traffic controller under Reg.37 of the Civil Aviation Regulations 1953 (S.R.1953/ 108; reprinted S.R.1962/13), is distinguishable from the general legislative activity and should be dealt with as an administrative rather than as a legislative function, and therefore within the second category or, in respect of 
an individual Crown servant's personal failure, the first category above.

The fourth and most difficult category is official activity in respect of uniquely governmental functions. There are some general considerations which are relevant to the imposition of tort liability for all such activity, viz. alternative remedies, the measure of damages, the related economic factor of the total cost to the community of allowing claims in this area and the issues whether and what official activity in respect of governmental functions should be reviewed by the courts. As to these:

(a) alternative remedies: In respect of some at least of the official functions which would come within the present category, the citizen affected may have a remedy available in the supervisory jurisdiction of the Courts exercised by medium of the writs of certiorari and prohibition, the order of mandamus, injunction; and the action for a declaration, or he may have a right of review or of appeal or a defence in the way of a plea of ultra vires to enforcement proceedings. By the use - of these proceedings he can have the element of illegality, if not always of error, in the official action eliminated or made ineffective. The individual in this situation may have suffered losses accrued up to the time when he obtained relief and even losses 
which have to be assessed by reference to periods after that date, e.g. in respect of a lost business opportunity. If he can obtain rectification of the wrongful element in the official activity by an alternative remedy he should not be able to obtain general damages from the community, for he will have obtained the fair treatment he should have received in the first instance - cf. Jaffe: Judicial Control of Administrative Action (1965) pp.236 et seq. His remedy should thereafter be confined to the extent of his provable accrued losses, if indeed he should be allowed a further remedy at all. In cases in which alternative remedies have been barred by statute, the legislative intention should be taken to include the barring of all tort liability as well and provision made accordingly.

(b) measure of damages: In respect of tort actions against public officers, damages have been awarded on both an exemplary or punitive and a compensatory basis - see e.g. Rookes v. Barnard [1964] A.C.1129, 1221-1233 (p.151 above) and Schinotti v. Bumsted (1796) 6 T.R. . 646; 101 E.R.750 (p.119 above). It is suggested (p.192 below) that Crown servants should be immune from personal suit in respect of their official activities, and there appears to be no good reason for making the community purse pay punitive damages. Accordingly, 
there should be no right to award punitive damages (cf. s.2674 of the Federal Tort Claims Act - above p.66). It may be that compensatory damages will be increased in some cases for injury to feelings and dignity (cf. Mayne and NcGregor on Damages $12 \mathrm{Ed}$. (1961) p.200 para.212 et seq.), but this would not be a departure from principle - cf. Rookes v. Barnard (supra) as to aggravated damages. The Courts' experience in the development of principles for the assessment of compensatory damages (as witness the size of the text-book last referred to) will certainly be equal to the task of assessing compensatory damages in actions against the State.

Allied to the question of the measure of damages is the economic question of the total cost to the community of allowing a tort remedy in respect of uniquely governmental functions. The state in New Zealand is already subject to most of the liabilities in tort to which it is now suggested it properly should be and the cost to the community has not yet proved to be too great. The number of actions brought against the state, apart -from the common personal injury and property damage claims (which are anticipated and provided for from year to year), is relatively small and their cost not prohibitive. Should the cost become excessive, legislation would provide a remedy and it is suggested that experience would provide the only valid basis for a 
determination of this issue.

(c) whether it is appropriate that the Courts should determine the issues: It may be accepted that the ordinary Courts are not appropriate bodies to be the ultimate arbiters of administrative discretion. The United States Federal Tort Claims Act is fashioned on this proposition and the United States Supreme Court's discretionary/operational distinction accords with it, as does the proposal made above in respect of the limitation of 'enterprise liability' to the operation of what is in fact provided. The area in which real difficulty arises is when the act in issue is the act of deciding. If the Court may not examine or determine the content of the decision, it can only be concerned with the procedure by which it was reached and will be unable to reach all the issues relevant to a tort liability decision. If it is accepted that damages should be compensatory only, the Court caninot determine them, because the determination of what would be the correct administrative decision is a necessary pre-requisite to such a determination (pp.149-151 above). There has been so little development of tort remedies in relation to the making of discretionary decisions and there appears to be so little room for development of such remedies within the Court's 
legitimate sphere that it would be reasonable to follow the American precedent and eliminate doubt by legislative provision. Furthermore, if it is not proper for the Court to determine the merits of any discretionary decision, there is no point in allowing it to go into such issues as whether only proper considerations have been taken into account in arriving at the decision. The United States provision to this effect is sound and should be adopted also. Where what is in issue is not the act of deciding, but is action or omission which directly affects the person or property of the citizen, the point on which issue is joined being whether or not the defendant's act was justified by law or his omission contravened the law, the difficulties last discussed do not arise and the issues are readily determinable by the Courts within the rramework of the nominate torts. The Australian experience in particular provides substantial suppòrt for this view.

On the basis of these general considerations deeisions can be made in respect of various categories of official activity. Where the loss arises from the failure to perform a ministerial duty there appears to be no reason for refusing a tort remedy. The nature of the duty is determined as a matter of interpretation and the issue 
whether or not the duty has been performed is readily determinable by the ordinary Courts. There seems to be no very weighty reason for refusing an action for breach of statutory duty if the plaintiff can show a sufficient personal interest and has suffered loss as a result of the breach, merely because the duty is one which applies to the Crown and its officers alone. The availability of the remedy should be modified where an alternative remedy is available. There appears to be no real need to make special provision prohibiting actions against the Crown in respect of failure to perform general public duties such as those imposed on Ministers ( $\mathrm{p} .30$ above) because the Courts would doubtless take a similar view in a tort action to that which would be taken in respect of an application for mandamus - cf. de Smith: Judicial Review of Administrative Action (1959) p.446, but if there is need, it would appear appropriate to exempt Ministers' functions from the application of this provision altogether, leaving thè enforcement of these to Parliamentary action.

In respect of official action other than the performance of ministerial duties, broad categories can be distinguished. It is unqestionably in the community's interest to allow a tort remedy in respect of the acts of government officials which directly affect the person or property of individual citizens and are not authorised by 
law. The propriety of such acts can readily be tested within the framework of the nominate torts. Difficulties which might arise in actions based on negligence, particularly in respect of omissions, would appear to be eliminated by a provision preserving from tort liability any decision involving the exercise of discretion, and for the reasons suggested above such provision should be made. Any act consequent on the exercise of discretion within jurisdiction would be an act authorised by law. From this it follows that the Courts would have to be left to determine whether the decision was made within jurisdiction, but to preserve the discretionary exclusion, issues as to jurisdiction would have to be strictly limited and not allowed to expand to include issues as to whether the deciding authority has taken into account all, and only, relevant considerations, or as to whether the conclusion of the deciding authority is so unreasonable that no reasonable authority could ever have reached it - cf. Associated Picture Houses Itd. V. Wednesbury Corporation [1948] I K.B. 223.

- The action for abuse of office referred to at page 140 above is a rarity which is difficult to fit into a patterned liability. Once the decision is made to eliminate the exercise of discretions from the field of tort liability, however, such actions as those in Farrington's case and Roncarelli's case would appear to be 
consequentially eliminated.

Official communications of State conveniently form a category on their own. As has been indicated in Chapter IV absolute privilege has been afforded communications between some officers of state (p.117), but it is not clear whether the immunity extends to cover communications between all ranks of public officers: Salmond on Torts 14 Ed. (1965) p.227 and Merricks v. Nott-Bower [1965] 1 Q.B. 57 where doubt was expressed whether the privilege to be accorded reports passing between senior police officers was absolute or qualified only. The device of absolute privilege (and indeed every other device giving immity) serves a double purpose - protection of the officer, but primarily the refusal of a remedy where the public interest requires that one should not be available - cf. Jaffe: Judicial Control of Administrative Action (1965) p.235. It appears that the Court in Merricks' case could see merit in absolute privilege, apparently on the basis of considerations similar to those which moved the majority of the Court in Barr v. Niatteo (1959) 360 U.S.564 (p.99 above) - see per Iord. Denning at p.68 of the report. What gave the Court pause was the decision in Gibbons v. Duffell (1932) 47 C.I.R.520, an appeal from a judgment of the Supreme Court of New South Wales which had held that reports passing between police officers on a staff matter 
were absolutely privileged on the ground that the public interest required it. In the passage on which the court of Appeal in Merrick's case based its doubt Gavan Duffy C.Jo, Rich and Dixon JJ. said:

"The truth is that an indefeasible immunity for defamation is given only where upon clear grounds of public policy a remedy must be denied to private injury because complete freedom from suit appears indispensable to the effective performance of judicial, legislative or official functions. The presumption is against such a privilege and its extension is not favoured .... Its application should end where its necessity ceases to be evident." ( 47 C.I.R. at 528).

The Court of six judges agreed that the privilege was qualified and not absolute.

It is not insignificant that the joint judgment referred to above continued a few lines later:

"Possibly upon a balance of convenience it might be better for the Force, if worse for the individual, that libel actions between policemen should be disallowed. But the Legislature has not said so, and there is no sufficient warront in the principles of cominon law for denying to one police officer the protection of the law from malicious defamation by another." (p.528).

There seems, however, to be no strong reason for suggesting that all commications between State officers, whatever their rank, should be absolutely privileged. Freedom to write or speak frankly is much more likely to be necessary in respect of proposals than of persons and the essential protection will be found in the rules 
relating to the production of documents, rather than in those relating to defamation. Adequate protection will be provided for the public interest in respect of defamation if the Courts are left to develop the extent of absolute privilege on a case by case basis, and the State stands behind its officers as sugested by Mr Justice Brennan in Barr v. Mlatteo (p.100 above).

In respect of all actions against the state it is necessary to decide for which of the persons who perform functions related to Government administration the Crown is to be liable and whether those persons should themselves be subjected to liability. In respect of the first issue, it is suggested that the Crown should undertake all liability which may arise in tort in respect of the activities of any person who is performing a function on behalf of the central government, whether or not that person is strictly a servant or an agent of the Crown for whose torts the Crown would ordinarily be responsible. Some limit must obviously be imposed on the Crown's liability and it is suggested, having regard to the discussion in Chapter $\mathrm{V}$ that a result reasonably fair to the injured citizen, to the public officer and to the community as a whole which bears the brunt of any lossspreading will be achieved if the limitation is based on the well recognised criterion of whether the public officer is acting in the course of his employment or in 
the execution of his duties.

As has been suggested above and in the Introduction, there is a societal interest in protecting public officens from personal liability in tort in respect of their official activities, in that such protection preserves their freedom to act and advise by removing fear of direct consequences to their own assets. On the other hand, there is an arguable societal interest in subjecting such officers to personal liability in that the possibility of personal liability, particularly for exemplary or punitive damages (cf. Rookes v. Barnard [1964] A.C.II29), is a safeguard to citizens against the abuse of power. It is further arguable that to subject the officer to personal liability is of assistance to the State in the supervision and control of its officers because indemnity can be provided or withheld at will. Professor Jaffe in Judicial Control of Administrative Action (1965) pp.238-9 suggests that the drawback to voluntary indemity by the state is that compensation may not be provided where the officer's offence and consequent damage are greatest.

Whether there should be statutory indernity or not is a matter for political choice and there is apparently not unanimity on the issue in New Zealand, e.g. when the Director-General of Health was sued for defamation by a subordinate officer of his Department, the Government 
indicated that the Director-General's legal costs might be met, but not any damages awarded (Iarl.Deb. Vol.336 p.2023 et seq.). In the debate which followed Opposition members who were former Ministers expressed the view that there should be no indemnity at all (ibid p.2029, 2034). They were not, however, supported by the former AttorneyGeneral, the Hon. H.G.R.Mason q.C., M.P. (ibid p.2032). On the other hand, when the Minister of Labour was sued for defamation in respect of a matter arising in the course of an industrial dispute the Government paid both damages and costs (Parl.Deb. Vol.336 pp.1583 et seq.).

Defamation actions tend to cloud the issue of indemnity, because by their nature the matters in issue generally carry an emotional overtone. When all the factors are weighed, however, it is suggested that the balance comes down in favour of indemity: the plaintiff is assured that his award will be met; the officer, who by his occupation is peculiarly exposed to the risk of litigation, does not have to underwrite this risk with his own assets; and detriments caused by State activity are spread over the community. Parliamentary control and internal discipline and supervision are not diminished. Indeed, in New Zealand the State has a power of surcharge which appears wide enough to be available to back up other disciplinary powers: s.26 Fublic Revenues Act 1953. 
It has been suggested ( $p .183$ above) that the abolition of the right to recover exemplary or punitive damages follows logically upon the granting of indemnity to public officers, and in my view there is little merit in arguments in favour of such damages. An armoury of weapons which will produce redress against the Crown and public officers has been developed in recent years and if such remedies are coupled with compensatory damages the community cannot fairly be asked to provide more. It has been suggested above that there is good reason for not making a public officer personally liable to pay damages at all in respect of his official acts. To suggest that he should be subjected to liability to pay punitive damages potentially greater than any fine which would be likely to be inflicted upon him were the matter regarded as a criminal rather than a civil one outrages every sense of what is fair.

The present New Zealand provision set out in full at p.2l above, provides for most of the liabilities in tort to which it has been suggested in this Chapter it is desirable the State should be subjected, and indeed, in some respects a foundation exists in the cases for the development of liability which I have suggested should be curtailed. Subject to the validity or acceptability of my suggested decisions in respect of the political 
questions involved, it is sugsested that a reform of the statute should provide:

(1) that the State is Iiable:

(a) vicariously for torts committed by employees, and by agents and independent contractors to the same extent as a private person would be liable;

(b) directly in respect of negligent non-feasance or other tort liabilities arising from enterprises which it operates which are of a commercial or service nature, but not in respect of the quality of the service provided or the failure to provide a service, or in respect of activities performed primarily for the public benefit rather than for private reliance;

(c) directly in respect of the duties owed by an employer to his employees;

(d) directly in respect of torts related to property;

(e) in respect of failure to perform ministerial duties or breach of statutory duty where other persons beside the Crown are bound by the statute or where only the Crown and its employees are bound, if in accordance with 
the usual test, the plaintiff can show a sufficient personal interest; but not in respect of general duties imposed on Ministers;

(2) that the State is not liable:

(a) in respect of the making within jurisdiction of any discretionary decision or in respect of any act performed with due care as a consequence of and in conformity with such a decision, with the proviso that in determining whether a decision was made within jurisdiction the Court should not inquire into the reasonableness of the decision or into the considerations taken into account in the making of the decision (p. 185 above);

(b) where an alternative remedy is available or is debarred by statute, except that in the former case action may be brought under paras.I(a) to (e) in respect of losses accrued to the date the alternative remedy might reasonably have been obtained;

(c) in respect of legislative functions (including delegated and subdelegated functions) or the functions of judicial 
officers of the Supreme Court or Magistrates acting within their jurisdictions;

(d) in respect of the acts or omissions of members of the armed forces, while on duty as such, which cause death or personal injury to another member of the ammed forces, provided that the latter is either on duty or is on any land, premises, ship or vehicle being used for the purposes of the armed forces of the Crown when the act or omission becomes effective (cf. s.10 Crown Proceedings Act 1947 (United Kingaom));

(e) for other than compensatory damages. The term "employees" should be defined as widely or, if necessary, more widely than the term "employees of the Government" in s.2671 of the Federal Tort Claims Act (p.68 above) and the availability of an action against the Government under the Act should be a bar to any action by the same claimant against the government employee whose act or omission gave rise to the claim. Where actions are specifically barred, i.e. in paras. (2)(a)-(d) above, the bar should apply also to actions against the employee. Provisions along the lines of $\mathrm{s.6(3)}$ of the present Act making the Crown liable although the function concerned is imposed on a particular officer personally by the common law or by statute, and of $\mathrm{s.6(4)}$ of the Act relating to 
limitations of liability, would be required. In respect of I cases covered by $2(d)$ above it would of course be essential to provide that a remedy by way of a war pension should be available (cf. s.9 Crown Proceedings Act 1950). It is suggested that, in this situation, to bar a tort remedy and prescribe a pension is preferable to making the barring of the tort remedy conditional on the granting of a pension as does the present s.9. The reasons for this choice are very much the same as moved the courts in the military defamation cases ( $p .113$ et seq. above).

Statutory provisions along the lines suggested (which would perhaps most suitably be drawn as a composite of the Federal Tort Claims Act and s.6 of the Crown Proceedings Act 1950) would both extend and modify the present New . Zealand statute and would provide adequate remedies for detriments caused by the activities of the State. Every State activity is not submitted to evaluation by the courts under this proposal, but it is fundemental to my thesis that limits should properly be set to the Courts' jurisdiction. The provisions suggested provide for compensation in all situations in which as between private persons compensation would be made and are wide enough to allow the testing of the legality of Government actions which directly affect the person or property of the individual and to provide compensation in respect of those which fail the test. The reasonableness of government 
decisions is kept from the Courts' review, compensation in money paid by the commity is confined to actual detriments which cannot otherwise be compensated and all losses are spread over the community. More than this cannot in my view be reasonably asked. 